\title{
26. GEOCHEMISTRY AND PETROGENESIS OF BASALTS FROM DEEP SEA DRILLING PROJECT LEG 92, EASTERN PACIFIC1
}

\author{
J. A. Pearce, N. Rogers, A. J. Tindle, and J. S. Watson, Department of Earth Sciences, The Open University, \\ Milton Keynes ${ }^{2}$
}

\begin{abstract}
Basalts recovered on DSDP Leg 92 include all the major basalt types so far recovered from the ocean crust of the eastern Pacific. Basalts from Holes 597, 597A, 597B, 597C, and 599B are tholeiites exhibiting all the mineralogical and geochemical characteristics of $\mathrm{N}$-type mid-ocean ridge basalts (MORB). Fragments of ferrobasalts and alkali basalts were also obtained, however, from Holes $601 \mathrm{~B}$ and $602 \mathrm{~B}$, respectively. Hole 597C, which penetrated $91 \mathrm{~m}$ into basement and is the deepest hole so far drilled in fast-spreading crust, yielded basalts that can be divided into three major lithologic units. The lowest unit, Unit III, contains modal olivine and comprises basalts which, at about 8 to $10 \% \mathrm{MgO}$, are as basic as any sampled from fast-spreading crust. The middle unit, Unit II, is the most evolved; its basalts are olivine free and contain between 6 and $7.5 \% \mathrm{MgO}$. The upper unit, Unit I, is intermediate in composition between Units II and III; it is characterized by both modal olivine and glomerocrysts made up of plagioclase and rare olivine. Unit I is probably a massive flow, whereas Units II and III may be massive flows or sills. The basalts appear to have undergone three stages of alteration ("deuteric," "relatively reducing," and "oxidizing"), the intensity of alteration decreasing markedly downcore. Hole 597B, at $26.4 \mathrm{~m}$ of basement penetration the only other "deep" hole, contains just one lithologic unit, which closely resembles Unit I of Hole 597C.

Petrogenetic modeling reveals that the three lithologic units in Hole 597C are cogenetic and that they were derived from a depleted mantle source similar to the source of the tholeiites and ferrobasalts sampled in other holes; the alkali basalts are the only rocks derived from enriched mantle. Lavas of Unit III probably lay on the olivine-plagioclase cotectic, whereas the other lavas lay on an olivine-plagioclase-clinopyroxene peritectic. Some $60 \%$ of closed-system crystallization is needed to generate the most-evolved from the last-fractionated tholeiite, and a further $50 \%$ crystallization $(80 \%$ overall) is needed to generate the ferrobasalts. Xenocrysts of calcic plagioclase and pseudomorphosed olivine in tholeiites from Hole 597B and Unit I of Hole 597C, and in the ferrobasalts from Hole 601B, provide evidence, however, that some magma mixing may have taken place.
\end{abstract}

\section{INTRODUCTION}

In this chapter we present whole-rock and mineral analyses for the basalts recovered during Leg 92 of the Deep Sea Drilling Project. We then use these data for routine classification of the basalts and for evaluation of their petrogenetic histories. Finally, we assess the contribution that these results make to our understanding of processes at fast-spreading ridges, with particular reference to the continuing debate on the role of steady-state magma chambers, the origin and setting of ferrobasalts, and the nature and extent of mantle heterogeneities.

The settings and locations of the Leg 92 sites are summarized in Figure 1, together with details of the basalt recovery at each site. Site 597 (about $28.5 \mathrm{Ma}$ ) is located on crust formed at the now-extinct Mendoza Rise, which was transformed into the East Pacific Rise by a series of ridge jumps between 20 and $6 \mathrm{Ma}$ (Rea, 1981). Site 598 (about $17 \mathrm{Ma}$ ), Site 599 (about $8 \mathrm{Ma}$ ), and Sites 600 to 602 (about $4.5 \mathrm{Ma}$ ) are all located on crust formed at the East Pacific Rise itself. Most significant as regards igneous processes is Hole 597C; this is now the deepest hole (91 $\mathrm{m}$ basement penetration) in fast-spread-

\footnotetext{
${ }^{1}$ Leinen, M., Rea, D. K., et al., Init. Repts. DSDP, 92: Washington (U.S. Govt. Printing Office).

Addresses: (Pearce, present address) Department of Geology, The University, Newcaste-upon-Tyne NE1 7RU, United Kingdom; (Rogers, Tindle, and Watson) Department of Earth Sciences, The Open University, Milton Keynes MK7 6AA, United Kingdom.
}

ing crust, the previous deepest being Hole 319A of DSDP Leg $34(59 \mathrm{~m})$, which was also drilled into Galapagos Rise crust (Yeats, Hart, et al., 1976). Core recovery in Hole $597 \mathrm{C}$ was also high $(48.5 \mathrm{~m})$. This hole thus provides the best opportunity so far to evaluate magma chamber processes at fast-spreading ridges. Holes 598 to 602 , by contrast, yielded only small quantities of basalt, but these do extend the geographic range of samples recovered from the eastern Pacific (see Scheidegger and Corliss, 1981), and they should therefore provide further information on compositional heterogeneities within the crust.

\footnotetext{
SAMPLING PROCEDURE AND ANALYTICAL TECHNIQUES

A total of 103 minicore samples was chosen for analysis from the basalts recovered during the leg. At least one sample was taken per $1.5-\mathrm{m}$ section, and areas of particular interest, such as possible cooling-unit boundaries, were sampled more intensively. Since the objective was to study the primary igneous geochemistry, the freshest parts of each section of core were sampled, and veins were avoided where possible. A slice from each minicore was used to prepare a polished thin section, and the remainder (about $50 \mathrm{~g}$ ) was crushed, first by a jaw-crusher and then to about 240 mesh by agate "tema" mill. Blanks prepared by this method showed negligible contamination for the elements of interest.

All samples were analyzed by Meca 10-44 energy-dispersive X-ray fluorescence (XRF) spectrometer for major elements (using fused discs) and for the trace elements $\mathrm{Zr}, \mathrm{Y}, \mathrm{Nb}, \mathrm{Cr}, \mathrm{V}, \mathrm{Ni}, \mathrm{Rb}, \mathrm{Sr}, \mathrm{Cu}$, and $\mathrm{Zn}$ (using powder pellets). Full details of the technique are given by Potts et al. (1984); results obtained on three international standards, run as unknowns, and on a shipboard standard are listed in Appendix A. The precision of the data is considered to be less than $5 \%$ for all elements
} 


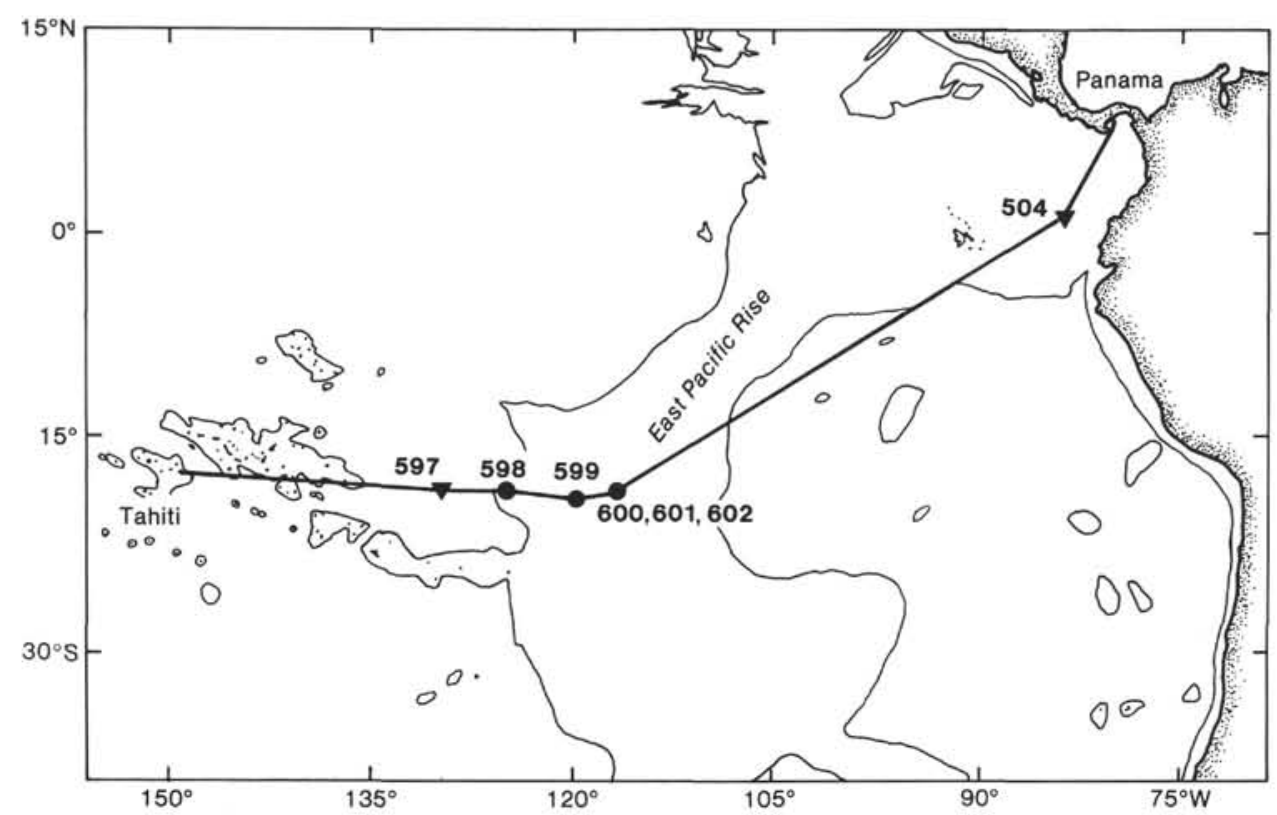

Figure 1. Site locations of DSDP Leg 92 and summary of basement drilling. Inverted triangle denotes reentry.

of interest, except $\mathrm{Rb}, \mathrm{Nb}, \mathrm{P}$, and $\mathrm{K}$, which are close to their detection limits in the analyzed samples and have precisions of 10 to $20 \%$. The full table of XRF analyses is given as Appendix B.

A subset of 18 representative samples was also analyzed by instrumental neutron activation analysis (INAA) for the rare earth elements (REEs), Th, Ta, Hf, Co, and Sc. Aliquots of $300 \mathrm{mg}$ were irradiated at the University of London reactor center at Ascot, and spectra were processed at the Open University, as described by Paul et al. (1975) and Potts et al. (1981). Full analyses of these samples are given in Table 1.

Microprobe analyses of mineral phases were performed at The Open University on an automated two-spectrometer Cambridge Instruments Microscan 9, using a defocused beam and operating conditions of $20 \mathrm{kV}$ and $30 \mathrm{nA}$. Natural and synthetic minerals were used as standards. The data are summarized in Tables 2 to 4 and are listed in full in Appendix C (pyroxenes), Appendix D (feldspars), and Appendix E (oxides). Only a tiny quantity of fresh glass and olivine was found: analyses of this material are given in Table 4 .

\section{LITHOLOGIES}

Detailed petrographic descriptions of the core are presented by Goldfarb (this volume). Here, we summarize the principal features relevant to the identification of lithologic units and to the construction of petrogenetic models.

\section{Hole 597B}

All core recovered from this hole consists of slightly vesicular basalt. Neither glass nor pillow structures were found, and the core is thus inferred to have sampled one or more massive flows. No geochemical or mineralogical boundaries were found within the core, but a number of distinctive dark, fine-grained zones, typically about $10 \mathrm{~cm}$ thick, do occur, and these have been tentatively interpreted as internal cooling zones within a single lithologic unit.

The primary mineralogy is typically plagioclase, clinopyroxene, and titanomagnetite, together with up to $5 \%$ olivine and, in the finer-grained samples, some cryptocrystalline groundmass. The rocks are only rarely por- phyritic, in terms of the grain size of individual crystals, but they do usually contain up to $10 \%$ glomerocrysts made up of plagioclase with occasional euhedral olivine. A number of plagioclase crystals within these glomerocrysts are distinctly calcic; they also typically exhibit more sodic rims and an internal zone of glass inclusions-evidence of a period of supercooling and injection into magma more evolved than their parent magma.

The degree of alteration is moderate throughout the core; all olivine and cryptocrystalline groundmass have been pseudomorphosed by clay minerals and iron oxyhydroxides. Studies of the sequences of vesicle and vein infilling and the mineralogy of alteration halos to intersecting veins reveal an essentially threefold sequence of alteration: an early (possibly deuteric) stage characterized by blue smectite; a second (relatively reducing) stage characterized by dark green smectite, together with talc, chlorite, and rare sulfides and native copper; and a final (relatively oxidizing) stage characterized by brown smectite, calcite, iron oxyhydroxides and low-temperature zeolites. This sequence is thus broadly similar to that described by Bass (1976) for basalts drilled during DSDP Leg 34. Owing to the high fracture- and vesicle-permeability of all recovered core, all the samples analyzed had experienced at least one episode of alteration.

\section{Hole 597C}

As in Hole 597B, no obvious flow boundaries were identified in the core recovered. Significant mineralogical and geochemical variations were observed, however, as illustrated in Figure 2. These provide the basis for the proposed subdivision into three lithologic Units: Unit I (the uppermost unit, $48 \mathrm{~m}$ thick); Unit II (the intermediate unit, about $20 \mathrm{~m}$ thick); and Unit III (the lowermost unit, at least $13 \mathrm{~m}$ thick). Petrographically, Unit I can be seen to contain both plagioclase glomerocrysts and oliv- 
Table 1. "Complete" geochemical analyses for selected samples of basalts from DSDP Leg 92.

\begin{tabular}{|c|c|c|c|c|c|c|c|c|c|c|c|c|c|c|c|c|c|c|}
\hline Hole & 597B & $597 \mathrm{~B}$ & $597 \mathrm{C}$ & $597 \mathrm{C}$ & $597 \mathrm{C}$ & $597 \mathrm{C}$ & $597 \mathrm{C}$ & $597 \mathrm{C}$ & $597 \mathrm{C}$ & $597 \mathrm{C}$ & $597 \mathrm{C}$ & $597 \mathrm{C}$ & $597 \mathrm{C}$ & $597 \mathrm{C}$ & 599B & $601 B$ & $601 \mathrm{~B}$ & $602 \mathrm{~B}$ \\
\hline Core-Section & $2-1$ & $3-2$ & $3-1$ & $4-1$ & $4-5$ & $5-2$ & $6-1$ & $7-1$ & $7-5$ & $8-2$ & $9-1$ & $10-1$ & $11-1$ & $12-1$ & $4-1$ & $2-1$ & $2-1$ & $1-2$ \\
\hline Level, cm & s5 & 27 & 52 & 126 & 120 & 24 & 128 & 12 & 90 & 43 & 129 & 119 & 93 & 20 & 14 & 43 & 105 & 99 \\
\hline Unit & & & I & 1 & I & I & 1 & I & 1 & II & II & II & III & III & & & & \\
\hline $\mathrm{SiO}_{2}$ & 49.74 & 50.10 & 49.68 & 50.25 & 49.71 & 50.37 & 49.95 & 49.79 & 49.96 & 50.62 & 50.25 & 50.26 & 49.52 & 49.33 & 50.51 & 49.75 & 50.76 & 47.52 \\
\hline $\mathrm{TiO}_{2}$ & 1.08 & 1.22 & 1.13 & 1.34 & 1.32 & 1.21 & 1.19 & 1.15 & 1.20 & 1.46 & 1.54 & 1.38 & 0.93 & 1.05 & 1.17 & 2.58 & 2.62 & 3.00 \\
\hline $\mathrm{Al}_{2} \mathrm{O}_{3}$ & 14.69 & 14.60 & 14.44 & 14.76 & 14.62 & 15.50 & 15.30 & 15.08 & 15.19 & 13.95 & 13.52 & 13.74 & 17.04 & 14.49 & 14.95 & 12.68 & 12.93 & 15.57 \\
\hline $\mathrm{Fe}_{2} \mathrm{O}_{3}$ & 10.63 & 10.52 & 10.19 & 11.41 & 11.62 & 11.25 & 10.98 & 11.63 & 11.14 & 12.67 & 13.35 & 12.32 & 9.58 & 10.39 & 9.96 & $165 t$ & 14.55 & 11.12 \\
\hline $\mathrm{MnO}^{-}$ & 0.16 & 0.15 & 0.16 & 0.16 & 0.16 & 0.16 & 0.16 & 0.15 & 0.17 & 0.18 & 0.19 & 0.18 & 0.14 & 0.17 & 0.16 & 0.25 & 0.21 & 0.18 \\
\hline $\mathrm{MgO}$ & 8.12 & 7.20 & 8.05 & 7.26 & 7.36 & 7.94 & 6.69 & 7.35 & 7.62 & 7.45 & 7.25 & 7.53 & 8.27 & 8.25 & 7.27 & 5.66 & 5.28 & 5.66 \\
\hline $\mathrm{CaO}$ & 12.73 & 12.41 & 12.24 & 11.80 & 11.77 & 12.11 & 12.41 & 12.23 & 12.20 & 11.26 & 11.14 & 11.59 & 12.88 & 12.55 & 12.43 & 9.84 & 9.70 & 8.87 \\
\hline $\mathrm{Na}_{2} \mathrm{O}$ & 2.64 & 1.97 & 2.02 & 2.56 & 2.34 & 2.50 & 2.19 & 2.17 & 2.22 & 2.84 & 2.61 & 2.68 & 1.96 & 2.11 & 2.93 & 2.83 & 2.78 & 4.31 \\
\hline $\mathrm{K}_{2} \mathrm{O}$ & 0.22 & 0.11 & 0.15 & 0.10 & 0.09 & 0.09 & 0.45 & 0.09 & 0.07 & 0.19 & 0.20 & 0.10 & 0.04 & 0.07 & 0.19 & 0.22 & 0.48 & 1.57 \\
\hline $\mathrm{P}_{2} \mathrm{O}_{5}$ & 0.12 & 0.16 & 0.13 & 0.11 & 0.12 & 0.14 & 0.11 & 0.13 & 0.15 & 0.17 & 0.16 & 0.15 & 0.13 & 0.09 & 0.09 & 0.23 & 0.28 & 0.67 \\
\hline $\mathrm{LOI}^{\mathrm{a}}$ & 0.52 & 0.32 & 0.69 & 0.19 & 0.41 & 0.53 & 0.65 & 0.23 & 0.40 & 0.17 & 0.09 & 0.24 & 0.75 & 0.58 & 0.42 & 0.10 & 0.61 & 1.09 \\
\hline Total & 100.65 & 98.76 & 98.88 & 99.94 & 99.52 & 101.80 & 100.08 & 100.00 & 100.32 & 100.96 & 100.30 & 100.17 & 101.24 & 99.08 & 100.08 & 100.65 & 100.20 & 99.56 \\
\hline $\mathrm{Zr}$ & 67 & 76 & 70 & 84 & 80 & 70 & 72 & 74 & 72 & 87 & 90 & 80 & 54 & 62 & 76 & 192 & 190 & 311 \\
\hline $\mathrm{Y}$ & 27 & 31 & 26 & 30 & 32 & 29 & 30 & 27 & 28 & 33 & 35 & 30 & 20 & 25 & 32 & 69 & 68 & 56 \\
\hline $\mathrm{Nb}$ & 4.1 & 4.1 & 3.7 & 4.6 & 5.1 & 3.1 & 4.6 & 4.3 & 3.8 & 4.0 & 5.2 & 3.9 & 3.3 & 4.1 & 2.1 & 4.9 & 4.4 & 42.0 \\
\hline $\mathbf{R b}$ & 4.7 & 2.5 & 4.3 & 3.3 & 3.6 & 2.3 & 12.5 & 2.6 & 3.2 & 3.8 & 4.0 & 3.0 & 1.4 & 2.5 & 7.2 & 3.0 & 8.0 & 19.6 \\
\hline $\mathrm{Sr}$ & 85 & 92 & 83 & 91 & 82 & 86 & 93 & 84 & 93 & 82 & 83 & 81 & 85 & 79 & 94 & 112 & 124 & 340 \\
\hline $\mathrm{Cr}$ & 334 & 278 & 312 & 196 & 211 & 283 & 279 & 324 & 266 & 145 & 88 & 107 & 374 & 319 & 264 & 74 & 52 & 135 \\
\hline $\mathrm{Ni}$ & 127 & 151 & 113 & 75 & 77 & 89 & 68 & 88 & 101 & 79 & 56 & 82 & 112 & 100 & 82 & 57 & 32 & 113 \\
\hline $\mathrm{v}$ & 332 & 342 & 277 & 352 & 353 & 330 & 280 & 306 & 298 & 352 & 406 & 361 & 260 & 318 & 253 & 427 & 450 & 257 \\
\hline $\mathrm{Cu}$ & 123 & 124 & 124 & 136 & 121 & 115 & 125 & 131 & 102 & 117 & 121 & 200 & 95 & 135 & 102 & 81 & 55 & 53 \\
\hline $\mathrm{Zn}$ & 81 & 89 & 74 & 84 & 88 & 75 & 85 & 80 & 67 & 77 & 80 & 77 & 60 & 64 & 84 & 138 & 116 & 102 \\
\hline $\mathrm{Hf}$ & 1.59 & 1.92 & 1.68 & 2.21 & 2.03 & 1.84 & 1.85 & 1.89 & 1.91 & 2.23 & 2.45 & 2.04 & 1.32 & 1.57 & 1.95 & 4.86 & 5.00 & 6.26 \\
\hline $\mathrm{Ta}$ & 0.15 & 0.20 & 0.19 & 0.24 & 0.23 & 0.21 & 0.20 & 0.21 & 0.21 & 0.26 & 0.28 & 0.22 & 0.15 & 0.17 & 0.00 & 0.27 & 0.24 & 2.47 \\
\hline Th & 0.30 & 0.40 & 0.39 & 0.33 & 0.30 & 0.50 & 0.26 & 0.27 & 0.30 & 0.24 & 0.25 & 0.20 & 0.22 & 0.30 & 0.60 & 0.33 & 0.40 & 3.13 \\
\hline $\mathrm{Sc}$ & 45.5 & 35.5 & 45.6 & 47.7 & 46.2 & 33.0 & 44.4 & 45.4 & 43.8 & 47.5 & 47.2 & 46.4 & 38.3 & 34.8 & 44.6 & 44.7 & 33.6 & 32.2 \\
\hline $\mathrm{Co}$ & 50.0 & 50.0 & 48.4 & 46.2 & 43.1 & 43.0 & 45.0 & 44.5 & 43.0 & 47.2 & 49.9 & 44.1 & 41.5 & 43.0 & 42.0 & 44.0 & 39.0 & 30.0 \\
\hline $\mathrm{La}$ & 2.5 & 3.0 & 3.2 & 3.8 & 3.2 & 2.7 & 3.0 & 3.2 & 3.2 & 3.9 & 4.2 & 3.1 & 2.1 & 2.6 & 2.3 & 6.3 & 5.2 & 26.2 \\
\hline $\mathrm{Ce}$ & 7.7 & 9.3 & 8.1 & 10.1 & 9.2 & 8.6 & 9.0 & 8.7 & 8.7 & 10.2 & 10.5 & 9.0 & 6.3 & 7.7 & 7.9 & 18.8 & 19.2 & 59.4 \\
\hline $\mathrm{Nd}$ & 8.0 & 7.3 & 7.1 & 9.8 & 8.9 & 7.4 & 8.0 & 8.2 & 7.4 & 9.8 & 10.2 & 8.1 & 6.0 & 7.5 & 7.3 & 18.6 & 20.6 & 35.2 \\
\hline Sm & 2.45 & 2.83 & 2.55 & 3.10 & 2.97 & 2.68 & 2.73 & 2.67 & 2.67 & 3.26 & 3.37 & 2.83 & 1.94 & 2.34 & 2.84 & 6.53 & 6.60 & 8.16 \\
\hline $\mathrm{Eu}$ & 0.97 & 1.13 & 0.99 & 1.18 & 1.12 & 1.02 & 1.03 & 1.03 & 1.03 & 1.22 & 1.24 & 1.06 & 0.79 & 0.92 & 1.13 & 2.18 & 2.23 & 2.69 \\
\hline $\mathrm{Tb}$ & 0.72 & 0.76 & 0.70 & 0.87 & 0.81 & 0.68 & 0.71 & 0.69 & 0.72 & 0.88 & 0.87 & 0.74 & 0.53 & 0.62 & 0.78 & 1.61 & 1.60 & 1.43 \\
\hline Ho & 1.20 & 1.10 & 1.10 & 1.36 & 1.48 & 1.20 & 1.13 & 0.98 & 1.10 & 1.63 & 1.17 & 1.20 & 0.80 & 1.10 & 1.20 & 2.40 & 2.20 & 1.85 \\
\hline $\mathrm{Tm}$ & 0.47 & 0.48 & 0.43 & 0.53 & 0.52 & 0.47 & 0.46 & 0.50 & 0.44 & 0.56 & 0.56 & 0.41 & 0.35 & 0.41 & 0.45 & 1.01 & 1.00 & 0.71 \\
\hline $\mathrm{Yb}$ & 2.89 & 3.19 & 2.87 & 3.31 & 3.24 & 3.01 & 3.01 & 2.88 & 2.96 & 3.50 & 3.62 & 3.20 & 2.17 & 2.64 & 3.09 & 6.28 & 6.64 & 4.76 \\
\hline Lu & 0.48 & 0.53 & 0.52 & 0.57 & 0.56 & 0.50 & 0.51 & 0.50 & 0.50 & 0.60 & 0.60 & 0.52 & 0.37 & 0.45 & 0.52 & 1.06 & 1.10 & 0.77 \\
\hline
\end{tabular}

Note: Elements $\mathrm{Si}$ to $\mathrm{Zn}$ were analyzed by XRF, elements $\mathrm{Hf}$ to $\mathrm{Lu}$ by INAA. Nondetected $\mathrm{Ta}$ is given as $0 . \mathrm{SiO}^{2}$ to $\mathrm{LOI}$ in wt. $\% ; \mathrm{Zr}$ to $\mathrm{Lu}$ in ppm.

a $\mathrm{LOI}=$ loss on ignition.

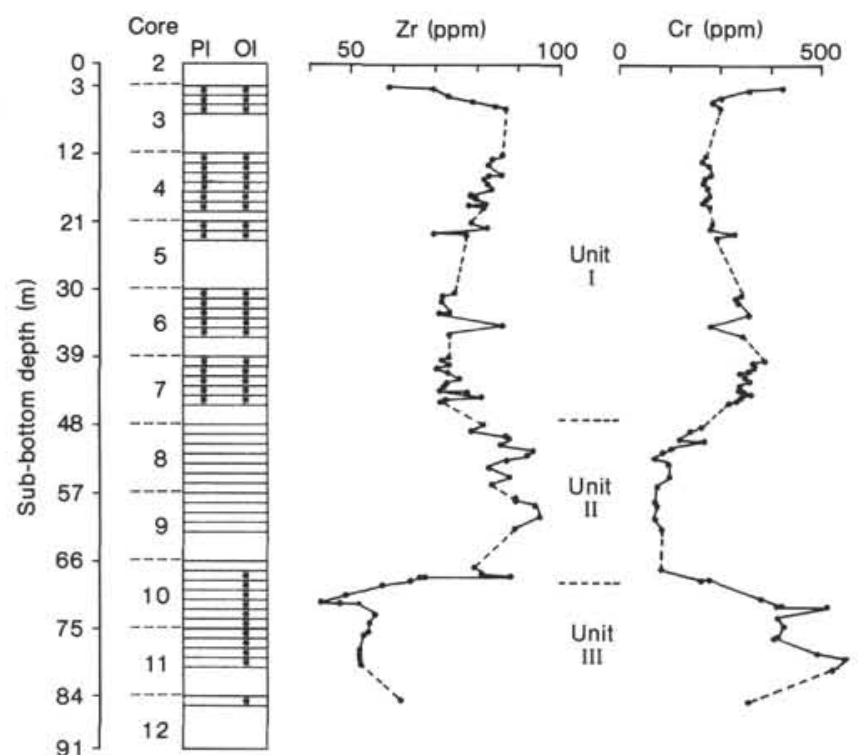

Figure 2. Geochemical stratigraphy of Hole $597 \mathrm{C}$ as exemplified by the elements $\mathrm{Zr}$ and $\mathrm{Cr}$. Core sections containing plagioclase glomerocrysts $(\mathrm{Pl})$ and modal olivine $(\mathrm{Ol})$ are indicated by stars in boxed column. ine and thus resembles the core from Hole 597B. Unit II basalts are aphyric and olivine free. Unit III basalts are generally aphyric and contain up to $10 \%$ modal olivine. Geochemical profiles, exemplified in Figure 2 by the incompatible element $\mathrm{Zr}$ and the compatible element $\mathrm{Cr}$, also show significant inflections at these petrographic boundaries. It might also be argued, on the basis of Figure 2, that the uppermost $5 \mathrm{~m}$ of Unit I belong to a fourth unit; but we decided to restrict the subdivision to the three major groups that can be identified by both petrographic and geochemical characteristics.

Interestingly, neither inferred boundary corresponds to an obvious textural or structural discontinuity. The boundary between Units I and II is located in a region of low core recovery between Cores 7 and 8 , but that between Units II and III is located within Core 10, where recovery was high. The latter boundary was originally thought to correspond to one of the enigmatic fine-grained zones, but can be seen in Figure 2 to be a transitional rather than an abrupt boundary. It was also thought that Units II and III could represent a single flow in which olivine accumulated at its base: chemical variation diagrams (presented later) show, however, that basalts within these units do not lie along olivine control lines. We therefore suggest that this discontinuity-and perhaps the other one as well-represents an internal flow boundary whereby a new pulse of magma is inject- 
ed within a partly cooled flow. This hypothesis is evaluated in more detail in subsequent sections.

Alteration, vesicularity, and texture vary systematically with depth. The basalt is slightly vesicular in the top $45 \mathrm{~m}$, below which it is nonvesicular. The three stages of alteration identified in Hole 597B are also found here. Alteration intensity is greatest in the vesicular part of the core, below which it is restricted to halos around veins. In the lower half of the core, segments between veins can be very fresh, although olivine (if present) is invariably altered. Textures range from spherulitic to ophitic, except for a single 1-cm-wide glassy rind in the uppermost fragment. Ophitic textures are most common in Units II and III, where zoned poikilitic crystals of augite up to $2 \mathrm{~cm}$ across are common. Feldspars sometimes exhibit layering in this part of the core. The order of crystallization is clearly (1) olivine, (2) plagioclase, (3) clinopyroxene, (4) Ca-poor pyroxene (Unit III), (5) titanomagnetite.

\section{Holes 599A, 601B, and 602B}

Although the quantity of basalt recovered from these holes is very small, the petrographic diversity is great. At Site 599, the basalts are almost nonvesicular, with spherulitic to intergranular textures. They are slightly plagioclase phyric and contain a groundmass of altered olivine, plagioclase, titanomagnetite, and cryptocrystalline matrix. They thus strongly resemble Unit I of Hole 597C.

At Site 601, the basalts are typically made up of microphenocrysts of plagioclase, clinopyroxene, and (altered) olivine in a groundmass of altered olivine, plagioclase, clinopyroxene, and patches of yellow glass. In some samples, coalesced spherulites of plagioclase fibers and clinopyroxene dendrites containing abundant interstitial magnetite give the sample an opaque appearance in thin section, a feature described by Natland (1980) as typical of ferrobasalts. Sulfide inclusions in magnetite are common. The microphenocrysts include isolated tabular and skeletal crystals of plagioclase and glomerocrysts containing plagioclase + olivine and plagioclase + clinopyroxene. The largest olivine and clinopyroxene crystals have euhedral outlines; the largest plagioclase crystals are often calcic and occasionally exhibit resorbed rims.

At Site 602, the basalt samples are vitrophyric and contain microphenocrysts of pink skeletal titanaugite, olivine, and plagioclase.

\section{MAJOR-ELEMENT CHARACTERISTICS}

Both primary and secondary major-element variations can be recognized in the analyzed samples. Secondary variations are most obvious in the losses on ignition (LOIs) and in the abundances of elements of lowest ionic potential, notably $\mathrm{K}$ and $\mathrm{Na}$, both of which vary systematically with alteration intensity. Figure 3 shows a typical plot, that of $\mathrm{K}_{2} \mathrm{O}$ against LOI. In the most altered units (Hole 597B and Unit I of Hole 597C), the freshest samples are characterized by $\mathrm{K}_{2} \mathrm{O}$ values of less than $0.2 \%$ and by LOI values of less than $0.5 \%$; with increasing alteration intensity (vesicle and open-space infilling), both $\mathrm{K}_{2} \mathrm{O}$ and LOI increase. Alteration direction 1 is most common, reflecting the replacement of ol- ivine and cryptocrystalline groundmass and the infilling of vesicles by smectite; direction 2 is followed only by veined samples containing other (less potassium-rich) hydrous and carbonated minerals. High $\mathrm{K}_{2} \mathrm{O}$ values in the more evolved basalts of Hole 601B may, however, be explained by fractional crystallization, as well as by alteration. In the freshest unit, Unit II of Hole 597C, almost all samples contain less than $0.2 \% \mathrm{~K}_{2} \mathrm{O}$ and $0.4 \%$ LOI. In Unit III of Hole 597C, however, LOI can be high even though $\mathrm{K}_{2} \mathrm{O}$ concentration is generally very low. Since this unit differs from Unit II only by the presence of modal olivine, it can be inferred that the alteration direction (3) followed by these samples is due to the replacement of olivine by the (potassium-free) hydrated oxides and hydroxides of iron.

From the evidence we have presented, it is possible to use the dashed line in Figure 3 to screen analyses from Holes 597B and 597C before plotting them on petrological diagrams that are based on the alkali elements. Mobilities of other major elements-such as loss of $\mathrm{Mg}$ in Units I and III of Hole 597C, resulting from olivine breakdown-are less important, as demonstrated by the coherent variations in the diagrams based on these elements.

Figure 4 shows the distribution of screened data on the projection of the normative basalt tetrahedron (Yoder and Tilley, 1962). In common with most other MORB suites, almost all samples are tholeiitic (olivine or quartz tholeiites), the only exception being the basalt from Hole $602 \mathrm{~B}$, which is Ne-normative and can hence be classified as "alkalic." Of the tholeiitic samples, the most evolved samples (i.e., those from Unit II of Holes 597C and 601B) plot predominantly in the quartz-tholeiite field, whereas other samples (from Hole 597B and Units I and II of Hole 597C) plot predominantly in the olivine tholeiite field. Altered samples (not plotted in Fig. 4) show the same intergroup relationships but a greater spread toward the olivine and nepheline apices.

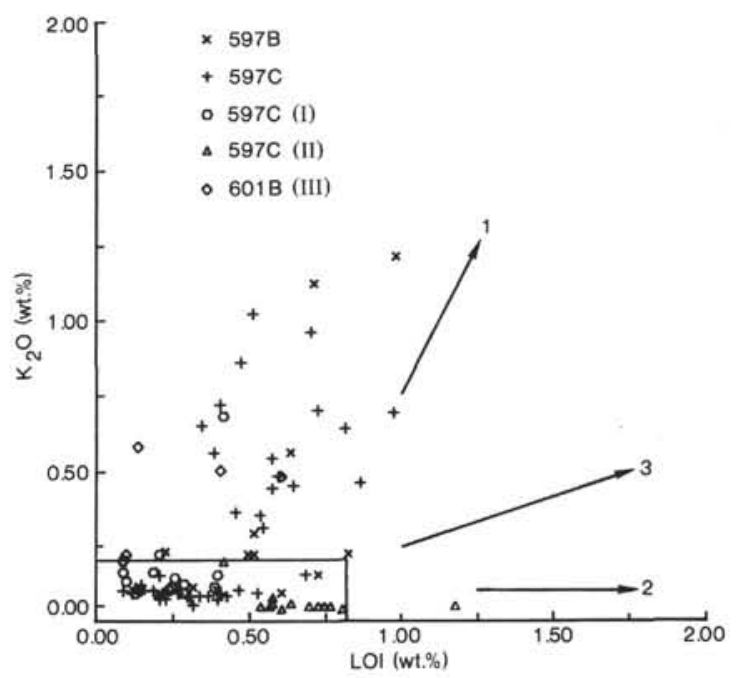

$+$

Figure 3. Plot of $\mathrm{K}_{2} \mathrm{O}$ against LOI (loss on ignition) for tholeiitic basalts. Vectors, 1,2 , and 3 indicate chemical changes due to alteration (see text); samples treated as "fresh" plot within the rectangle in the bottom left of the diagram. 


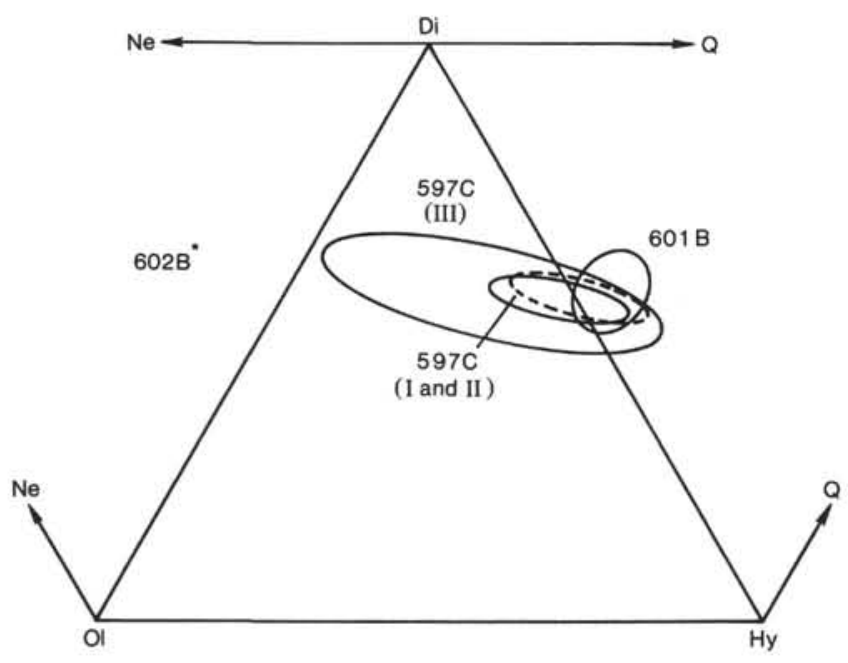

Figure 4. Projection of analyses of "fresh" samples onto the diopsidehypersthene-olivine plane of the normative basalt tetrahedron. The ellipses represent the $90 \%$ probability contours for the lithologic units indicated.

On the AFM diagram of Figure 5, all except the sample from Hole 602B follow the iron-enrichment trend characteristic of the tholeiitic series. In Hole 597C, Unit III defines the most basic end of the trend, and Units I and II exhibit progressive enrichment in iron. The samples from Hole 601B show the greatest enrichment. The latter have total $\mathrm{FeO}$ contents between 12.66 and 14.06 wt. $\%$ and $\mathrm{TiO}_{2}$ concentrations between 2.58 and 2.73 wt. $\%$, thus satisfying the criteria $(>12.0 \%$ and $>2.0 \%$, respectively: Byerly et al., 1976; Natland, 1980) for classification as "FETI" basalts or "ferrobasalts." Altered samples (not plotted on this diagram) show the same interrelationships but are displaced to higher alkali values (i.e., toward "A").

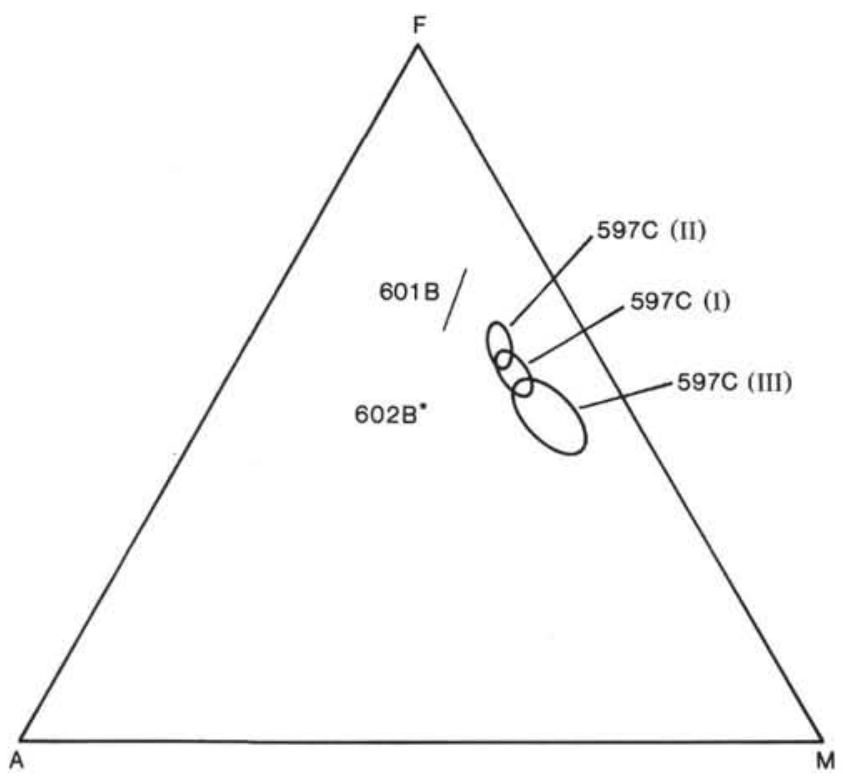

Figure 5. Projection of analyses of "fresh" samples onto the AFM triangle. As in Figure 4, the lithologic units are represented as $90 \%$ probability contours.

\section{TRACE-ELEMENT CHARACTERISTICS}

The principal trace-element characteristics are illustrated in Figures 6 and 7 by means of geochemical patterns. In the conventional rare-earth-element (REE) patterns shown in Figure 6, all the tholeiitic basalts can be seen to exhibit light-REE-depleted patterns with normalized $\mathrm{La} / \mathrm{Yb}$ ratios generally between 0.6 and 0.8 and normalized intermediate- to heavy-REE abundances between 10 and 18, all within the 2-sigma range for $\mathrm{N}$-type MORB (Basaltic Volcanism Study Project, 1981). The
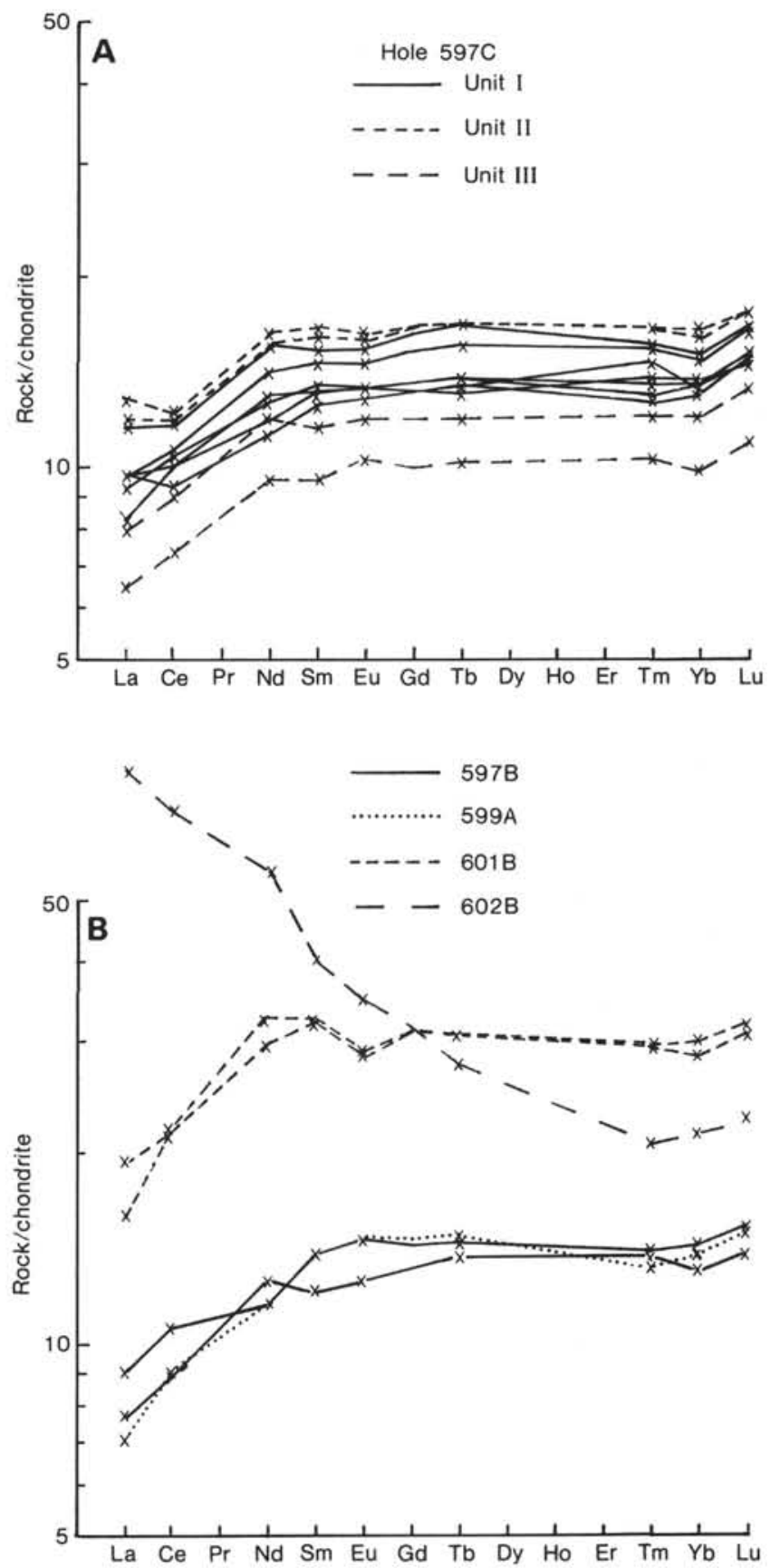

Figure 6. Chondrite-normalized rare earth patterns. A. Hole 597C. B. Other Leg 92 basalts. Normalizing values are taken from Nakamura (1974). 
ferrobasalts of Hole 601B exhibit patterns that are similar in shape but are displaced to higher abundances and have small negative Eu anomalies; these patterns strongly resemble the REE patterns described by Clague et al. (1981) and Perfit et al. (1983) for ferrobasalts from the Galapagos spreading center. The pattern for the alkali basalt of Hole 602B shows an enrichment in the light REEs comparable to that observed in E-type MORB suites from the North Atlantic (Tarney et al., 1980).

"Complete" trace-element patterns, normalized to an estimated primordial mantle composition (Wood, 1979), are presented in Figure 7. The patterns of all tholeiitic basalts and ferrobasalts show depletion in the most lithophilic elements, a feature characteristic of N-type MORB. Moreover, all patterns are subparallel, indicating derivation from sources of similar composition, in this case the incompatible-element-depleted convecting upper mantle. The alkali basalt pattern, which shows a relative enrichment in the most incompatible elements, is comparable to that of E-type MORB. The negative $\mathrm{Sr}$ anomalies indicate the extent of plagioclase fractionation, which increases from Unit III of Hole 597 to Hole 601B.

\section{MINERAL CHEMISTRY}

\section{Pyroxenes}

Pyroxenes from Leg 92 are almost all groundmass crystals, which have been subdivided in Appendix $C$ into variolitic, intergranular, and ophitic types. Some representative analyses are given in Table 2 . Figure 8 shows the distribution of compositions on the pyroxene quadrilateral. The most common trend is that exhibited by Holes 597B and 597C, in which Ca decreases and the $\mathrm{Fe} / \mathrm{Mg}$ ratio increases with fractionation. Unit III of Hole 597C additionally contains a significant group of $\mathrm{Ca}$-poor pyroxenes. The few samples analyzed from the ferrobasalts of Hole 601B have similar (i.e., augitic) compositions, whereas the titanaugite microphenocrysts from Hole 602B are relatively calcic, plotting on the Di-Hed tie-line. The latter also plot, predictably, in the "alkaline" fields of pyroxene classification diagrams, such as

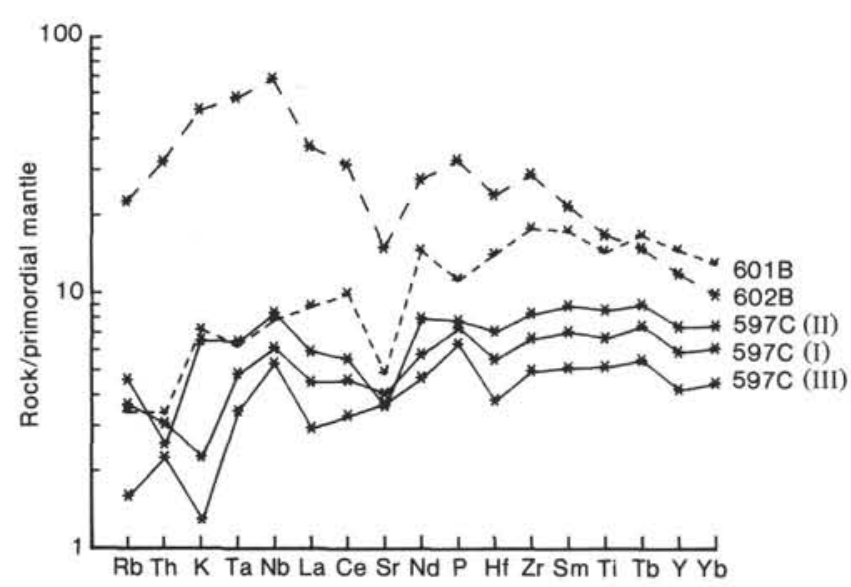

Figure 7. Primordial-mantle-normalized trace-element patterns for some "fresh" basalts representative of the various lithologic units. Normalizing values are taken from Wood (1979). the $\mathrm{SiO}_{2}-\mathrm{Al}_{2} \mathrm{O}_{3}$ diagram of Le Bas (1962). The interpretation of these trends, which are typical of moderately undercooled MORB suites from other areas, is described in detail in the literature (e.g., Muir and Mattey, 1982; Mattey and Muir, 1980). The final three columns of Table 2 also demonstrate the strong zonation found in some ophitic crystals: the rims of these crystals exhibit the greatest iron enrichment of any Leg 92 pyroxenes.

\section{Plagioclase}

Figure 9 summarizes, in histogram form, the range of feldspar compositions listed in Appendix D. From this, it is evident that there is a bimodal distribution of compositions in Holes 597B, 597C (Units I and III), and $601 \mathrm{~B}$, the bulk of the analyses ranging from $\mathrm{An}_{50}$ to $\mathrm{An}_{75}$ and a second, smaller group ranging from $\mathrm{An}_{80}$ to $\mathrm{An}_{90}$. The latter compositions are restricted to glomerocrysts, where they form large, weakly zoned crystals with irregular, resorbed or thin, more sodic margins. Probe traverses across four such crystals are given in Table 3. Zones of glass inclusions sometimes occur between the cores and sodic margins of the crystals, indicating a sudden period of rapid growth. These features have been recognized in a number of other MORB suites (see descriptions by, e.g., Dungan and Rhodes, 1978; Natland et al., 1983; Stakes et al., 1984), where they have been used as evidence that the calcic crystals are xenocrysts picked up from the margins of the magma chamber or introduced into the magma chamber via a more primitive host. The less calcic group of analyses derives from both glomerocryst and matrix crystals, and it clearly crystallized in equilibrium with the host magma. These crystals are predictably most calcic, on average, in Unit III of Hole 597C and most sodic in Hole 601B.

\section{Other Phases}

Unfortunately, two of the genetically important phases, olivine and glass, are poorly represented in the Leg 92 basalts, glass because of the paucity of pillow margins and olivine because of ubiquitous alteration. The only data obtained in this study are presented in Table 4 and are insufficient for making detailed interpretations. Titanomagnetite analyses are given in Appendix E and show compositions similar to those described by Mazzullo and Bence (1976) for Leg 34 basalts, plotting on or close to the $\mathrm{Fe}_{2} \mathrm{TiO}_{4}-\mathrm{Fe}_{2} \mathrm{O}_{3}$ tie-line on the $\mathrm{TiO}_{2}-\mathrm{FeO}$ $\mathrm{Fe}_{2} \mathrm{O}_{3}$ triangle. Ilmenite does occur, primarily in Unit II of Hole 597C; the composition of a typical ilmenitemagnetite pair is given in Table 4, and further analyses are listed by Nishitani (this volume).

\section{PETROGENETIC MODELING}

As we have demonstrated, the tholeiites from Holes 597B and 599B and from the three lithologic units of Hole $597 \mathrm{C}$, together with the ferrobasalts from Hole $601 \mathrm{~B}$, have trace-element patterns that indicate derivation from depleted mantle sources of similar compositions. We now carry out petrogenetic modeling to investigate the partial melting of these mantle sources and the subsequent evolution of the primary magma. The principles are illustrated by the ternary diopside-anor- 
Table 2. Average electron microprobe analyses (wt.\%) of pyroxenes from DSDP Leg 92 basalts.

\begin{tabular}{|c|c|c|c|c|c|c|c|c|c|c|c|c|c|c|c|c|c|c|}
\hline $\begin{array}{l}\text { Hole } \\
\text { Unit }\end{array}$ & 597B & 597B & 597B & $\begin{array}{c}597 \mathrm{C} \\
1\end{array}$ & $\begin{array}{c}597 \mathrm{C} \\
\text { I }\end{array}$ & $\begin{array}{c}597 \mathrm{C} \\
\mathrm{I}\end{array}$ & $\begin{array}{c}597 \mathrm{C} \\
\text { II }\end{array}$ & $\begin{array}{c}597 \mathrm{C} \\
\text { II }\end{array}$ & $\begin{array}{c}597 \mathrm{C} \\
\text { III }\end{array}$ & $\begin{array}{c}597 \mathrm{C} \\
\text { III }\end{array}$ & $\begin{array}{c}597 \mathrm{C} \\
\text { III }\end{array}$ & $\begin{array}{c}597 \mathrm{C} \\
\text { III }\end{array}$ & 599B & $601 \mathrm{~B}$ & $602 \mathrm{~B}$ & $\begin{array}{l}\text { 597B } \\
\text { Rim }\end{array}$ & $\begin{array}{l}\text { 597B } \\
\text { Int. }\end{array}$ & $\begin{array}{l}597 \mathrm{~B} \\
\text { Core }\end{array}$ \\
\hline Petrology $y^{a}$ & $\mathrm{v}$ & I & $\mathbf{P}$ & $\mathrm{v}$ & I & $\mathrm{P}$ & $i$ & $\mathrm{P}$ & $\mathrm{v}$ & 1 & $\mathrm{P}$ & $\bullet$ & 1 & 1 & $\mathrm{p}$ & $\mathrm{P}$ & $\mathrm{P}$ & $\mathbf{P}$ \\
\hline No. of analyses & 2 & 2 & 12 & 9 & 9 & 16 & 6 & 15 & 1 & 13 & 6 & 6 & 3 & 3 & 2 & 1 & 1 & 1 \\
\hline $\mathrm{SiO}_{2}$ & 51.14 & 50.47 & 50.98 & 51.20 & 51.73 & 51.35 & 51.15 & 51.62 & 53.43 & 52.52 & 53.02 & 53.37 & 51.33 & 51.70 & 44.10 & 50.54 & 51.75 & 52.25 \\
\hline $\mathrm{TiO}_{2}^{2}$ & 0.84 & 0.97 & 0.85 & 0.87 & 0.74 & 0.79 & 0.72 & 0.67 & 0.43 & 0.50 & 0.43 & 0.41 & 0.85 & 1.03 & 4.78 & 1.01 & 0.77 & 0.41 \\
\hline $\mathrm{Al}_{2} \mathrm{O}_{3}$ & 3.62 & 4.08 & 2.53 & 3.34 & 2.94 & 3.11 & 1.87 & 2.11 & 2.44 & 2.01 & 2.15 & 0.78 & 3.44 & 2.81 & 7.75 & 2.52 & 2.81 & 2.50 \\
\hline $\mathrm{FeO}$ & 8.48 & 9.76 & 12.88 & 9.60 & 10.09 & 9.21 & 14.29 & 12.06 & 5.89 & 8.21 & 6.52 & 18.92 & 8.80 & 9.74 & 9.07 & 16.21 & 8.81 & 5.39 \\
\hline $\mathrm{MnO}$ & 0.22 & 0.26 & 0.33 & 0.25 & 0.26 & 0.24 & 0.38 & 0.34 & 0.16 & 0.23 & 0.20 & 0.49 & 0.26 & 0.27 & 0.18 & 0.40 & 0.23 & 0.16 \\
\hline $\mathrm{MgO}$ & 15.88 & 14.94 & 14.67 & 15.77 & 15.71 & 16.01 & 14.62 & 15.57 & 17.07 & 16.60 & 17.39 & 21.21 & 16.49 & 16.13 & 11.04 & 14.66 & 15.93 & 16.86 \\
\hline $\mathrm{CaO}$ & 19.65 & 19.00 & 17.34 & 17.48 & 18.63 & 18.79 & 16.98 & 17.51 & 20.74 & 19.34 & 19.80 & 4.85 & 18.12 & 18.25 & 22.08 & 14.75 & 19.38 & 21.02 \\
\hline $\mathrm{Na}_{2} \mathrm{O}$ & 0.26 & 0.36 & 0.27 & 0.24 & 0.25 & 0.25 & 0.26 & 0.24 & 0.19 & 0.29 & 0.22 & 0.08 & 0.33 & 0.34 & 0.60 & 0.32 & 0.26 & 0.25 \\
\hline $\mathrm{Cr}_{2} \mathrm{O}_{3}$ & 0.24 & 0.17 & 0.09 & 0.13 & 0.17 & 0.13 & 0.01 & 0.04 & 0.45 & 0.17 & 0.34 & 0.00 & 0.10 & 0.05 & 0.09 & 0.00 & 0.09 & 0.73 \\
\hline Total & 100.30 & 100.00 & 99.94 & 98.89 & 100.52 & 99.89 & 100.28 & 100.17 & 100.80 & 99.86 & 100.07 & 100.10 & 99.72 & 100.31 & 99.69 & 100.41 & 100.03 & 99.57 \\
\hline $\mathrm{Ca}$ & 40.6 & 40.0 & 36.3 & 38.7 & 38.5 & 38.9 & 35.0 & 36.0 & 42.2 & 39.6 & 40.3 & 9.9 & 37.9 & 37.8 & 49.6 & 30.8 & 40.0 & 43.2 \\
\hline $\mathrm{Mg}$ & 45.7 & 43.9 & 42.7 & 45.7 & 41.9 & 46.2 & 42.0 & 44.5 & 48.4 & 47.3 & 49.3 & 58.2 & 47.7 & 46.5 & 34.5 & 42.7 & 45.8 & 48.2 \\
\hline $\mathrm{Fe}$ & 13.7 & 16.1 & 20.1 & 15.6 & 16.3 & 14.9 & 23.0 & 19.5 & 9.4 & 13.2 & 10.4 & 30.1 & 14.4 & 15.7 & 15.9 & 24.5 & 14.2 & 8.6 \\
\hline
\end{tabular}

$\mathrm{a}_{\mathrm{I}}=$ intersertal; $\mathrm{V}=$ variolitic; $\mathrm{P}=$ poikilitic; $\mathrm{p}=$ microporphyritic; $\cdot$ = pigeonite.
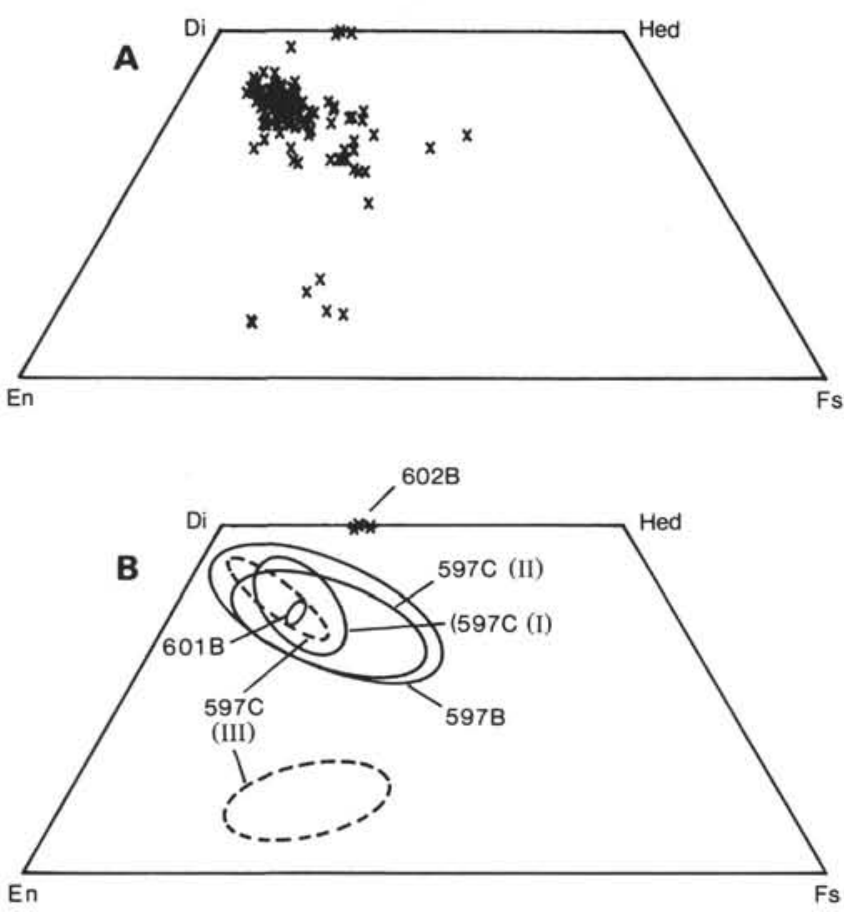

Figure 8. Pyroxene data from Leg 92 basalts plotted on the pyroxene quadrilateral (A) as data points and as (B) $90 \%$ probability ellipses for the individual lithologic units.

thite-forsterite diagram in Figure 10, on which phase boundaries for the synthetic diopside-anorthite-forsterite system have been superimposed (Osborn and Tait, 1952; Shido et al., 1971). In this system, a source composition, S, melts to give a primary melt, $\mathrm{P}$, leaving a residue, $R$. The composition $P$ then evolves by olivine fractionation to the olivine-plagioclase cotectic $\approx$ $\mathrm{O}$ and then moves to the olivine-plagioclase-clinopyroxene peritectic Pe. Normative compositions of the freshest aphyric rocks from Leg 92 (stars on Fig. 10) have also been plotted to identify the phase boundaries of the "real" system. Graphic and numeric modeling enable the compositions $\mathrm{S}, \mathrm{P}, \mathrm{R}, \mathrm{C}$, and $\mathrm{Pe}$ to be determined, with the proviso that the path $\mathrm{C}$ to $\mathrm{Pe}$ can be complicated by open-system fractionation if magma of this composition is repeatedly mixed with primitive magma of composi- tion between $\mathrm{C}$ and $\mathrm{P}$. It will be noted that petrographic evidence constrains the pathway by indicating that, in common with other N-type MORB sequences, the crystallization history is (1) olivine, (2) plagioclase, (3) clinopyroxene. The following diagrams and calculations enable this pathway to be investigated.

\section{Least-Squares Modeling Based on Major-Element Abundances}

Least-squares modeling (linear programming) is probably the most effective way to evaluate fractionation trends by simultaneous consideration of all major elements. The technique used here closely follows that described by Wright and Doherty (1970) and Mallet (1978), using the mini-max method of calculation and incorporating weightings according to errors associated with the individual measurements. The major-element oxides used were $\mathrm{SiO}_{2}, \mathrm{Al}_{2} \mathrm{O}_{3}$, total iron as $\mathrm{FeO}, \mathrm{MgO}, \mathrm{CaO}, \mathrm{Na}_{2} \mathrm{O}$, and $\mathrm{TiO}_{2}$. Statistically calculated weightings were, respectively, $10,25,40,40,100,10$, and $7500 . \mathrm{K}_{2} \mathrm{O}$ was not included because of its sensitivity to alteration; $\mathrm{MnO}$ and $\mathrm{P}_{2} \mathrm{O}_{5}$ were omitted because of the relatively large errors associated with their measurement and the fact that they provide information similar to that provided by $\mathrm{FeO}$ and $\mathrm{TiO}_{2}$, respectively. Phases used were forsteritic and fayalitic olivine (analyses taken from Deer et al., 1966), calcic and sodic plagioclase (Samples 597C-6-3, $69 \mathrm{~cm}$ [analysis 1-C in Table 3] and 597B-3-2, $27 \mathrm{~cm}$ [analysis 1 from Appendix D]) and clinopyroxene (Samples 597C$11-1,93 \mathrm{~cm}$ [analysis 3] and 597C-9-4, $93 \mathrm{~cm}$ [analysis 1] from Appendix C). To obtain an underdetermined set of equations, it was necessary additionally to assume a value for $K_{d}(\mathrm{Fe} / \mathrm{Mg})(\mathrm{ol} / \mathrm{cpx})$, the distribution coefficient for the $\mathrm{Fe} / \mathrm{Mg}$ ratio between olivine and clinopyroxene. A value of 0.8 (see discussion and references in Stakes et al., 1984) was used to model trends in which olivine and clinopyroxene crystallized simultaneously throughout; otherwise, a higher value (nominally 1.0) was taken. Two sets of calculations were performed: the first examined the trend from the most basic unit (III) of Hole 597C to the most evolved unit (II) of Hole $597 \mathrm{C}$; the second investigated the trend from the most basic suite (Unit III of Hole 597C) to the most evolved (the ferrobasalts of Hole 601B). More detailed break- 

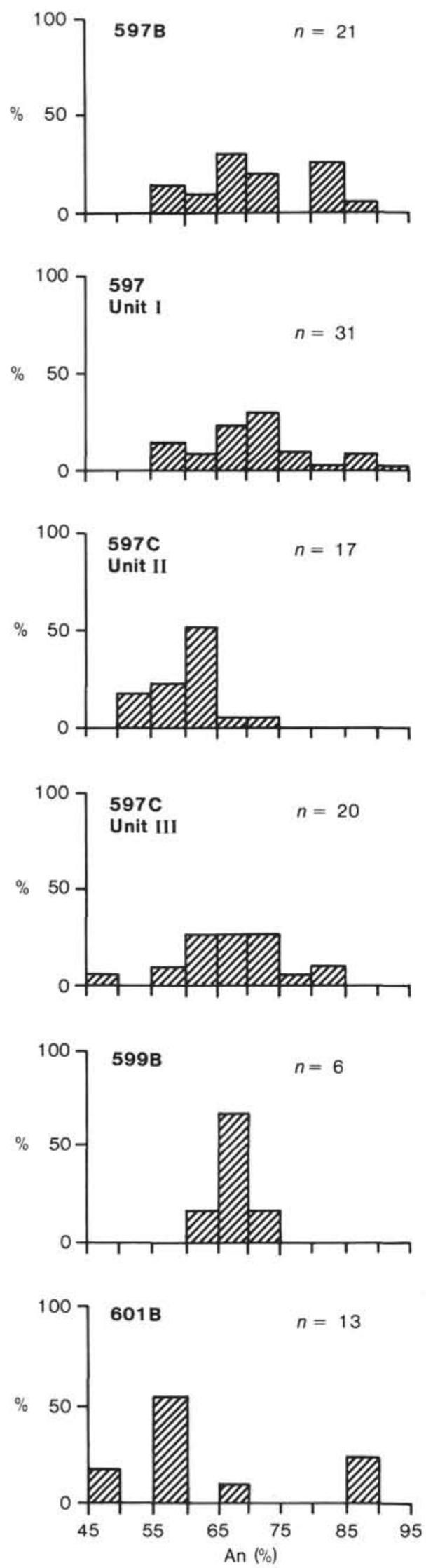

Figure 9. Histograms of plagioclase compositions from the various tholeiitic lithologic units. $n=$ no. of analyses. down of the fractionation trend gave poor results, as indicated by high sums of residuals.

The results of the first study are listed in Table 5. Samples 597C-10-5, $55 \mathrm{~cm}$ and 597C-9-4, $8 \mathrm{~cm}$ were chosen as the most suitable starting and residual compositions, respectively, both being aphyric and among the freshest rocks sampled. To confirm the consistency of the results, several runs were performed using a range of alternative compositions. It is apparent from Table 5 that consistent results were obtained, bearing in mind likely variations within each unit. This preliminary investigation therefore indicates that Unit II could have been derived by closed-system fractional crystallization from Unit III involving 48 to $69 \%$ crystallization ( $F=$ 0.31 to 0.52 ) of an olivine (7.5 to $12.5 \%$ ), clinopyroxene (32.1 to $40.9 \%$ ), plagioclase (51.2 to $56.5 \%$ ) assemblage. Calculated compositions of these phases are also given in the table. Both proportions and compositions of phases are slightly dependent on the chosen $K_{d}(\mathrm{Fe} / \mathrm{Mg})(\mathrm{ol} /$ cpx) value, as shown in the final four rows of Table 5; the removal of the oxide weightings can be seen to have negligible effect on the solution, however.

The results of the model deriving the ferrobasalts from Unit III of Hole 597C are shown in Table 6. Sample $601 \mathrm{~B}-2-1,105 \mathrm{~cm}$ has been chosen as the most suitable ferrobasalt for modeling, although the program was run using each ferrobasalt in turn as the residual composition. Results are again internally consistent, and indicate degrees of fractional crystallization between 76 and $84 \%(F=0.16$ to 0.24$)$ and crystallization assemblages of olivine ( 7.7 to $10.4 \%$ ), clinopyroxene ( 38.4 to $41.6 \%$ ), and plagioclase (48.9 to $52.0 \%$ ). This assemblage differs little from that of Table 5 , although $F$ is predictably smaller and the calculated phase compositions are richer in sodium and iron.

\section{Graphic Modeling of Major-Element Variations}

Oxide-MgO plots have been shown to be among the most effective for major-element modeling (e.g., Wright, 1974). Figure 11 presents plots of $\mathrm{CaO}, \mathrm{FeO}$, and $\mathrm{Al}_{2} \mathrm{O}_{3}$ against $\mathrm{MgO}$ for the least altered samples $\left(\mathrm{K}_{2} \mathrm{O}<0.20 \%\right.$, except Hole 601B); in each plot, the upper diagram shows the observed variations and the lower diagram the interpretation in terms of the compositions of crystallizing phases. Two bulk crystallizing assemblages are shown in each case: the first (X1) represents the assemblage for the olivine-plagioclase cotectic, using the most calcic plagioclase xenocryst analysis and an estimate of the composition of the coexisting olivine; the second (X2) represents the three-phase assemblage (from Table 6) required to explain the fractionation from Unit III of Hole 597 to the ferrobasalts of Hole 601B.

It is apparent from Figure 11, first, that the main component of variation passes through $\mathrm{X} 2$, thus confirming the result of the least-squares modeling. Unit II of Hole 597C exhibits an additional component of variation directed toward plagioclase, indicating that plagioclase cumulation has taken place, a result supported by the petrographic evidence presented earlier. In addition, there is a small inflection in the slope of the fractionation trends on both the $\mathrm{Al}_{2} \mathrm{O}_{3}-\mathrm{MgO}$ and $\mathrm{CaO}-\mathrm{MgO}$ 
Table 3. Reconnaissance electron microprobe analyses (wt.\%) of rims (R), intermediate locations (L), and cores (C) in four feldspar phenocrysts.

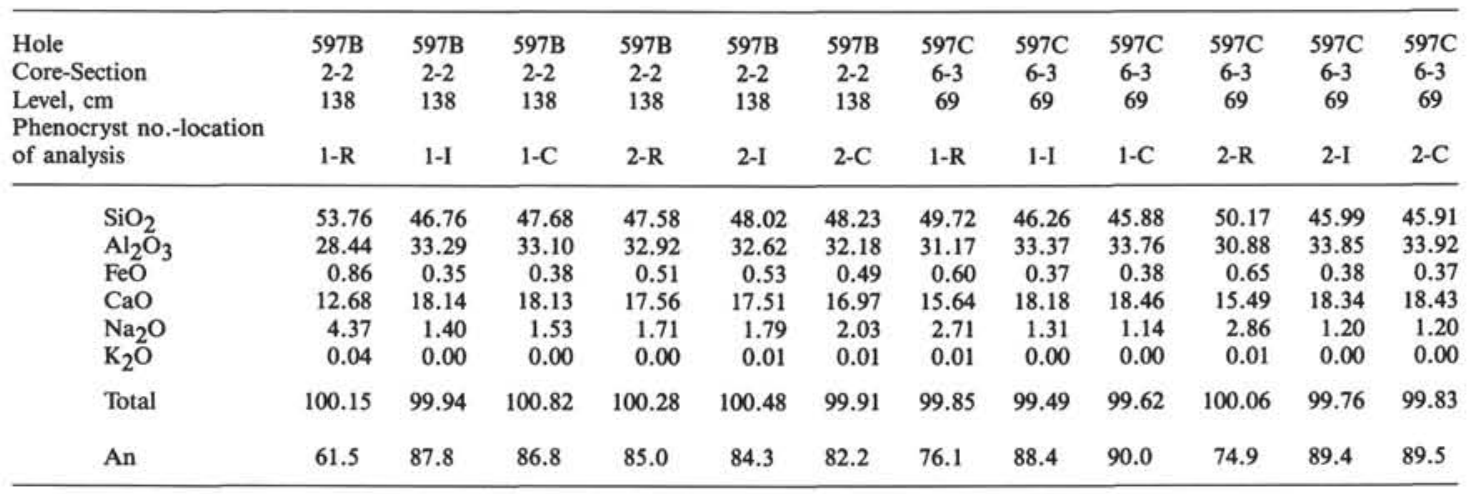

Table 4. Additional microprobe data (wt.\%) on phases from Leg 92 basalts.

\begin{tabular}{|c|c|c|c|c|c|c|c|c|}
\hline \multirow{4}{*}{$\begin{array}{l}\text { Hole } \\
\text { Core } \\
\text { Level, cm }\end{array}$} & \multicolumn{3}{|c|}{ Glass } & \multicolumn{3}{|c|}{ Olivine } & \multicolumn{2}{|c|}{$\begin{array}{c}\text { Ti-magnetite/ } \\
\text { ilmenite }\end{array}$} \\
\hline & $597 \mathrm{C}$ & $597 \mathrm{C}$ & $597 \mathrm{C}$ & $602 \mathrm{~B}$ & $602 \mathrm{~B}$ & $602 B$ & $597 \mathrm{C}$ & $597 \mathrm{C}$ \\
\hline & $3-1$ & $3-1$ & $3-1$ & $1-2$ & $1-2$ & $1-2$ & $8-4$ & $8-4$ \\
\hline & 3 & 3 & 3 & 99 & 99 & 99 & 23 & 23 \\
\hline $\mathrm{SiO}_{2}$ & 50.91 & 50.95 & 50.65 & 40.07 & 40.13 & 39.71 & 0.26 & 3.67 \\
\hline $\mathrm{TiO}_{2}$ & 0.65 & 0.78 & 0.72 & 0.05 & 0.04 & 0.04 & 19.51 & 46.92 \\
\hline $\mathrm{Al}_{2} \overline{\mathrm{O}}_{3}$ & 14.52 & 14.48 & 13.08 & - & - & - & 1.60 & 0.38 \\
\hline $\mathrm{FeO}$ & 7.90 & 7.41 & 9.51 & 16.76 & 16.26 & 18.41 & 73.19 & 44.98 \\
\hline $\mathrm{MnO}$ & 0.19 & 0.17 & 0.23 & 0.26 & 0.26 & 0.31 & 0.44 & 0.46 \\
\hline $\mathrm{MgO}$ & 9.33 & 9.24 & 8.16 & 43.94 & 44.36 & 42.67 & 0.27 & 1.86 \\
\hline $\mathrm{CaO}$ & 14.71 & 15.55 & 15.50 & - & - & - & 0.11 & 0.07 \\
\hline $\mathrm{Na}_{2} \mathrm{O}$ & 1.95 & 1.91 & 1.96 & - & - & - & - & - \\
\hline $\mathrm{K}_{2} \mathrm{O}$ & 0.05 & 0.02 & 0.06 & - & - & - & - & - \\
\hline Total & 100.21 & 100.51 & 99.87 & 101.35 & 101.31 & 101.40 & 95.38 & 98.54 \\
\hline Fo & & & & 82.4 & 82.9 & 80.5 & & \\
\hline
\end{tabular}

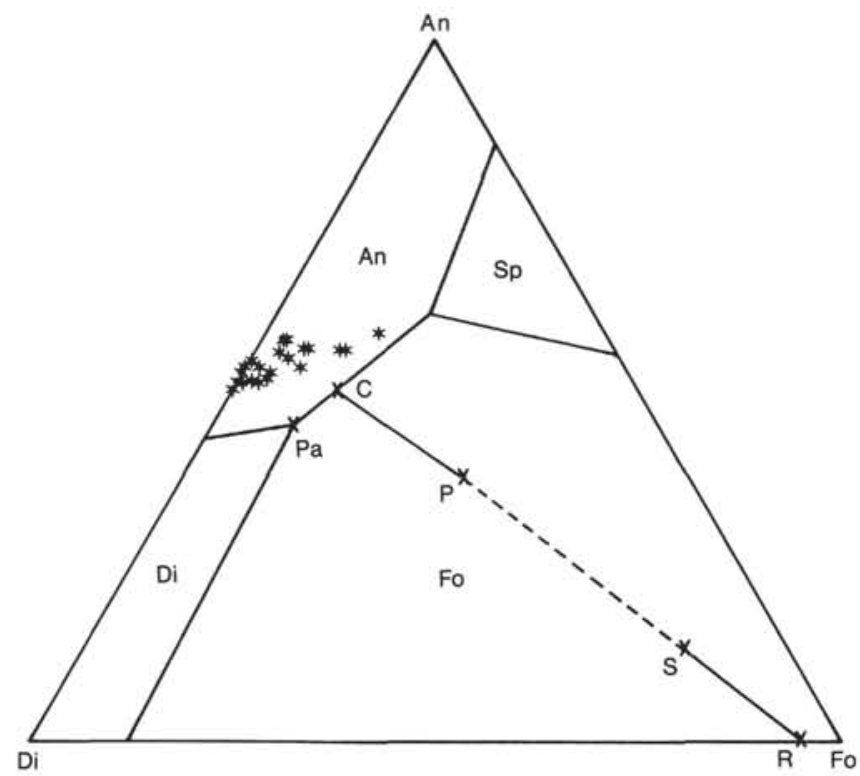

Figure 10. Diopside-anorthite-forsterite diagram showing phase fields (for $1 \mathrm{~kb}$. pressure) for diopside (Di), anorthite (An), forsterite (Fo), and spinel (Sp), and the probable mantle source (S) and residue $(R)$ compositions and probable crystallization paths from primary magma $(\mathrm{P})$ to the three-phase peritectic $(\mathrm{Pe})$. Compositions of fresh basalts (stars) have also been plotted on the basis of their normative pyroxene, plagioclase, and olivine proportions. diagrams. The relative positions of $\mathrm{X} 1$ and $\mathrm{X} 2$ indicate that this inflection corresponds to the incoming of clinopyroxene as a crystallizing phase. If so, this takes place at about $8 \% \mathrm{MgO}$, which corresponds well with the value of $8.4 \%$ determined by Stakes et al. (1984) for the FAMOUS area. It can also be seen from the FeO$\mathrm{MgO}$ diagram that $\mathrm{FeO}$ decreases with decreasing $\mathrm{MgO}$ in the ferrobasalts, indicating that (unless this component is due to cumulation) titanomagnetite became a crystallizing phase at an $\mathrm{MgO}$ value of about $5.75 \%$.

It may further be noted from these diagrams that the good correspondence between the least-squares and graphic modeling, together with the linear fractionation trends and clearly defined discontinuities, all argue for the dominance of closed-system fractional crystallization over the open-system fractionation (repeated fractional crystallization and mixing with primitive magma) proposed by O'Hara (1977). Thus, although petrographic evidence (calcic plagioclase xenocrysts) suggests that open-system fractional crystallization may have operated, it is likely that few mixing cycles were involved, and unlikely that a steady-state composition was reached.

\section{Study of Plagioclase Compositions}

The models presented in the foregoing sections explain variations observed in the erupted lavas, but do not provide information on the early history of crystallization in the olivine phase volume or on the olivineplagioclase cotectic. The point at which plagioclase becomes a crystallizing phase can, however, be estimated from Figure 12, a plot of $X \mathrm{An}$ against $\mathrm{Mg}$ number. The histogram of Figure 9 confirmed the presence, in Unit I of Hole 597C and the ferrobasalts of Hole 601B, of calcic plagioclase xenocrysts $\left(\mathrm{An}_{80}-\mathrm{An}_{90}\right)$. In Figure 12, two lines have been drawn to show the range of plagioclase compositions that resulted from liquidus (upper line) to near-solidus (lower line) crystallization from magmas of given $\mathrm{Mg}$ number. Projection of the xenocryst compositions onto the linear extrapolation of the liquidus line gives a minimum range of 60 to 77 for the $\mathrm{Mg}$ number of the host magma to the xenocrysts. The upper boundary of this range (which corresponds to an $\mathrm{MgO}$ value of $11 \%$ in the melt) gives a minimum value for the $\mathrm{Mg}$ number of the melt when plagioclase starts to crystallize 
Table 5. Linear programming model for derivation of Unit III lavas of Hole 597C from Unit II lavas of Hole $597 \mathrm{C}$ by closed-system fractional crystallization (see text for discussion).

\begin{tabular}{|c|c|c|c|c|c|c|c|c|c|c|}
\hline \multicolumn{11}{|c|}{ Starting composition: $597 \mathrm{C}-10-5,55 \mathrm{~cm}$} \\
\hline \multirow[b]{2}{*}{ Residue } & \multicolumn{4}{|c|}{$\begin{array}{c}\text { Phase } \\
\text { proportions }(\%)\end{array}$} & \multicolumn{5}{|c|}{$\begin{array}{c}\text { Phase } \\
\text { compositions (\%) }\end{array}$} & \multirow{2}{*}{$\begin{array}{l}\text { Sum of } \\
\text { squares of } \\
\text { residuals }\end{array}$} \\
\hline & $\mathrm{F}$ & $\mathrm{OI}$ & Cpx & PI & Fo & Wo & En & Fs & An & \\
\hline $97 C-9-2$, & 0.35 & 7.8 & 39.3 & 52.8 & 76.1 & 38.8 & 48.1 & 13.2 & 77.9 & 0.009 \\
\hline $597 \mathrm{C}-9-3,57 \mathrm{~cm}$ & 0.31 & 7.5 & 40.9 & 51.6 & 74.6 & 38.2 & 47.6 & 14.2 & 77.2 & 0.010 \\
\hline $597 \mathrm{C}-9-4,93 \mathrm{~cm}$ & 0.38 & 8.7 & 37.9 & 53.4 & 77.7 & 39.3 & 48.5 & 12.2 & 79.7 & 0.000 \\
\hline $597 \mathrm{C}-10-2,102 \mathrm{~cm}$ & 0.36 & 7.7 & 40.2 & 52.1 & 76.1 & 38.8 & 48.0 & 13.2 & 79.7 & 0.007 \\
\hline
\end{tabular}

Residual composition: $597 \mathrm{C}-9-4,93 \mathrm{~cm}$

\begin{tabular}{|c|c|c|c|c|c|c|c|c|c|c|}
\hline \multirow{2}{*}{$\begin{array}{l}\text { Starting } \\
\text { composition }\end{array}$} & \multicolumn{4}{|c|}{$\begin{array}{c}\text { Phase } \\
\text { proportions }(\%)\end{array}$} & \multicolumn{5}{|c|}{$\begin{array}{c}\text { Phase } \\
\text { compositions (\%) }\end{array}$} & \multirow{2}{*}{$\begin{array}{l}\text { Sum of } \\
\text { squares of } \\
\text { residuals }\end{array}$} \\
\hline & $\mathbf{F}$ & Ol & Cpx & $\mathrm{Pl}$ & Fo & Wo & En & Fs & An & \\
\hline $597 \mathrm{C}-11-3,128 \mathrm{~cm}$ & 0.51 & 10.7 & 36.3 & 53.0 & 84.3 & 41.3 & 50.4 & 8.3 & 88.8 & 0.352 \\
\hline $597 \mathrm{C}-11-4,73 \mathrm{~cm}$ & 0.52 & 11.4 & 32.1 & 56.5 & 82.6 & 40.8 & 50.0 & 9.2 & 86.1 & 0.067 \\
\hline $597 C-10-4,94 \mathrm{~cm}$ & 0.47 & 12.5 & 36.3 & 51.2 & 77.6 & 39.3 & 48.5 & 12.2 & 79.4 & 0.029 \\
\hline $597 \mathrm{C}-10-5,55 \mathrm{~cm}$ & 0.38 & 8.7 & 37.9 & 53.4 & 77.7 & 39.3 & 48.5 & 12.2 & 79.7 & 0.000 \\
\hline
\end{tabular}

Starting composition: $597 \mathrm{C}-10-5,55 \mathrm{~cm}$

Residual composition: $597 \mathrm{C}-9-4,93 \mathrm{~cm}$

\begin{tabular}{|c|c|c|c|c|c|c|c|c|c|c|}
\hline \multirow[b]{2}{*}{ Params. } & \multicolumn{4}{|c|}{$\begin{array}{c}\text { Phase } \\
\text { proportions }(\%)\end{array}$} & \multicolumn{5}{|c|}{$\begin{array}{c}\text { Phase } \\
\text { compositions (\%) }\end{array}$} & \multirow{2}{*}{$\begin{array}{l}\text { Sum of } \\
\text { squares of } \\
\text { residuals }\end{array}$} \\
\hline & $\mathrm{F}$ & $\mathrm{Ol}$ & Cpx & PI & Fo & Wo & En & Fs & An & \\
\hline Model 1 & 0.39 & 9.3 & 37.0 & 53.7 & 76.1 & 40.0 & 49.2 & 10.8 & 80.0 & 0.000 \\
\hline Model 2 & 0.38 & 8.7 & 37.9 & 53.4 & 77.7 & 39.3 & 48.5 & 12.2 & 79.7 & 0.000 \\
\hline Model 3 & 0.37 & 8.3 & 38.7 & 53.0 & 79.0 & 38.7 & 48.0 & 13.3 & 78.7 & 0.000 \\
\hline Model 4 & 0.39 & 9.3 & 37.0 & 53.7 & 75.9 & 40.0 & 49.1 & 10.9 & 79.8 & 0.000 \\
\hline
\end{tabular}

Model 1: $\mathrm{Fe} / \mathrm{Mg}(\mathrm{cpx}): \mathrm{Fe} / \mathrm{Mg}(\mathrm{ol})=0.8$; statistical weighting of elements

Model 2: $\mathrm{Fe} / \mathrm{Mg}(\mathrm{cpx}): \mathrm{Fe} / \mathrm{Mg}(\mathrm{ol})=1.0$; statistical weighting of elements

Model 3: $\mathrm{Fe} / \mathrm{Mg}(\mathrm{cpx}): \mathrm{Fe} / \mathrm{Mg}(\mathrm{ol})=1.2$; statistical weighting of elements

Model 4: $\mathrm{Fe} / \mathrm{Mg}(\mathrm{cpx}): \mathrm{Fe} / \mathrm{Mg}(\mathrm{ol})=1.0$; no weighting of elements

(point $\mathrm{C}$ in Fig. 10). If the fractional crystallization trends on the oxide-MgO plots in Figure 11 are extrapolated backward from this value, along olivine control lines, to an estimated primary magma composition at $\mathrm{MgO}=$ 17\% (Basaltic Volcanism Study Project, 1981), simple use of the "lever rule" then suggests that a maximum of $15 \%$ of olivine crystallized before plagioclase became a crystallizing phase.

\section{Trace-Element Modeling}

Results comparable to those from the major-element modeling are obtained using logarithmic trace-element covariation plots with $\mathrm{Zr}$ as the index of fractionation (Fig. 13). These diagrams can be used to compare observed fractionation trends with theoretical vectors, calculated from the Rayleigh fractionation equation

$$
C_{L}=C_{o} \cdot F^{(D-1)}
$$

for the likely crystallizing phases, olivine (o), plagioclase (p), clinopyroxene (c), and titanomagnetite (m). The vectors show how the melt composition will change in response to crystallization of these phases, the lengths of the vectors corresponding to $50 \%$ crystallization $(F=$ 0.5 ), except where indicated in the figure caption. The distribution coefficients $(D)$ used to calculate the vectors are taken from the compilations of Pearce and Norry (1979), Ottonello et al. (1984), Anderson and Greenland
(1969), and Philpotts and Schnetzler (1970). Provided that neither distribution coefficients nor phase proportions vary markedly during basalt fractionation, linear fractionation trends should be obtained for each crystallizing assemblage.

Figures 13A and 13B, based on $\mathrm{Y}$ and $\mathrm{P}$, show that all samples plot on a single linear trend, this trend being better defined using the more precise $\mathrm{Y}$ analyses. Since $\mathrm{Zr}, \mathrm{Y}$, and $\mathrm{P}$ are all incompatible with respect to the four crystallizing phases, the vectors and the observed trend all have slopes close to unity. The presence of a single trend also confirms the conclusion, reached earlier, that all the units plotted were derived from mantle sources of similar compositions. Since the lengths of the vectors correspond to $50 \%$ crystallization, it can be seen that some $75 \%$ crystallization is necessary to explain the derivation of the ferrobasalts from magma having the composition of Unit III of Hole 597C.

Figures $13 \mathrm{C}$ and 13D, based on $\mathrm{Ti}$ and $\mathrm{V}$, were chosen to investigate the role of titanomagnetite as a crystallizing phase. As the crystallization vectors indicate, titanomagnetite crystallization causes both $\mathrm{Ti}$ and $\mathrm{V}$ to be depleted in residual melt. That the ferrobasalts of Hole 601B plot off the main Hole 597C fractionation trend thus indicates that a small proportion of titanomagnetite was involved in the later stages of crystallization. The relatively large scatter on the $\mathrm{V}-\mathrm{Zr}$ plot can be attributed to curved mixing trends caused by plagioclase 
Table 6. Linear programming model for derivation of Hole 601B "ferrobasalts" from basalts of Unit II, Hole 597C by closed-system fractional crystallization (see text for discussion).

\begin{tabular}{|c|c|c|c|c|c|c|c|c|c|c|}
\hline \multicolumn{11}{|c|}{ Starting composition: $597 \mathrm{C}-10-5,55 \mathrm{~cm}$} \\
\hline \multirow[b]{2}{*}{ Residue } & \multicolumn{4}{|c|}{$\begin{array}{c}\text { Phase } \\
\text { proportions (\%) }\end{array}$} & \multicolumn{5}{|c|}{$\begin{array}{c}\text { Phase } \\
\text { compositions (\%) }\end{array}$} & \multirow{2}{*}{$\begin{array}{l}\text { Sum of } \\
\text { squares of } \\
\text { residuals }\end{array}$} \\
\hline & F & $\mathrm{Ol}$ & $\mathrm{Cpx}$ & Pl & Fo & Wo & En & Fs & An & \\
\hline $601 \mathrm{~B}-2-1,16 \mathrm{~cm}$ & 0.16 & 8.0 & 41.2 & 50.8 & 70.6 & 36.8 & 46.2 & 17.0 & 72.9 & 0.001 \\
\hline $601 \mathrm{~B}-2-1,43 \mathrm{~cm}$ & 0.18 & 7.7 & 40.3 & 52.0 & 72.9 & 37.6 & 47.0 & 15.4 & 73.2 & 0.001 \\
\hline $601 \mathrm{~B}-2-1,69 \mathrm{~cm}$ & 0.16 & 7.7 & 41.6 & 50.7 & 70.4 & 36.7 & 46.1 & 17.2 & 73.2 & 0.001 \\
\hline $601 \mathrm{~B}-2-1,105 \mathrm{~cm}$ & 0.17 & 7.8 & 41.2 & 51.0 & 71.1 & 37.0 & 46.4 & 16.7 & 74.0 & 0.001 \\
\hline
\end{tabular}

Residual composition: $601 \mathrm{~B}-2-1,105 \mathrm{~cm}$

\begin{tabular}{|c|c|c|c|c|c|c|c|c|c|c|}
\hline \multirow{2}{*}{$\begin{array}{l}\text { Starting } \\
\text { composition }\end{array}$} & \multicolumn{4}{|c|}{$\begin{array}{c}\text { Phase } \\
\text { proportions }(\%)\end{array}$} & \multicolumn{5}{|c|}{$\begin{array}{c}\text { Phase } \\
\text { compositions (\%) }\end{array}$} & \multirow{2}{*}{$\begin{array}{l}\text { Sum of } \\
\text { squares of } \\
\text { residuals }\end{array}$} \\
\hline & $\mathbf{F}$ & OI & Cpx & $\mathrm{Pl}$ & Fo & Wo & En & Fs & An & \\
\hline $597 \mathrm{C}-10-4,94 \mathrm{~cm}$ & 0.21 & 10.4 & 40.6 & 48.9 & 70.1 & 36.6 & 46.0 & 17.4 & 72.4 & 0.047 \\
\hline $597 \mathrm{C}-10-5,55 \mathrm{~cm}$ & 0.17 & 7.8 & 41.2 & 51.0 & 71.1 & 37.0 & 46.4 & 16.7 & 74.0 & 0.001 \\
\hline $597 \mathrm{C}-11-3,128 \mathrm{~cm}$ & 0.24 & 9.2 & 41.0 & 49.8 & 72.6 & 37.5 & 46.9 & 15.6 & 79.1 & 0.413 \\
\hline $597 \mathrm{C}-11-4,73 \mathrm{~cm}$ & 0.24 & 9.6 & 38.4 & 52.0 & 71.3 & 37.0 & 46.4 & 16.5 & 76.1 & 0.098 \\
\hline
\end{tabular}

Starting composition: $597 \mathrm{C}-10-5,55 \mathrm{~cm}$ Residual composition: $601 \mathrm{~B}-2-1,105 \mathrm{~cm}$

\begin{tabular}{|c|c|c|c|c|c|c|c|c|c|c|}
\hline \multirow[b]{2}{*}{ Params. } & \multicolumn{4}{|c|}{$\begin{array}{c}\text { Phase } \\
\text { proportions }(\%)\end{array}$} & \multicolumn{5}{|c|}{$\begin{array}{c}\text { Phase } \\
\text { compositions }(\%)\end{array}$} & \multirow{2}{*}{$\begin{array}{l}\text { Sum of } \\
\text { squares of } \\
\text { residuals }\end{array}$} \\
\hline & $\mathbf{F}$ & Ol & Cpx & $\mathrm{Pl}$ & Fo & Wo & En & Fs & An & \\
\hline Model 1 & 0.18 & 8.5 & 40.2 & 51.3 & 68.6 & 37.7 & 47.0 & 15.3 & 74.6 & 0.001 \\
\hline Model 2 & 0.17 & 7.8 & 41.2 & 51.0 & 71.1 & 37.0 & 46.4 & 16.7 & 74.0 & 0.001 \\
\hline Model 3 & 0.16 & 7.5 & 41.7 & 50.8 & 72.4 & 36.6 & 46.1 & 17.3 & 73.7 & 0.002 \\
\hline Model 4 & 0.16 & 7.8 & 41.2 & 50.9 & 70.8 & 36.8 & 46.3 & 16.9 & 73.5 & 0.001 \\
\hline
\end{tabular}

Model 1: $\mathrm{Fe} / \mathrm{Mg}(\mathrm{cpx}): \mathrm{Fe} / \mathrm{Mg}(\mathrm{ol})=0.8$; statistical weighting of elements

Model 2: $\mathrm{Fe} / \mathrm{Mg}(\mathrm{cpx}): \mathrm{Fe} / \mathrm{Mg}(\mathrm{ol})=1.0$; statistical weighting of elements

Model 3: $\mathrm{Fe} / \mathrm{Mg}(\mathrm{cpx}): \mathrm{Fe} / \mathrm{Mg}(\mathrm{ol})=1.2$; statistical weighting of elements

Model 4: $\mathrm{Fe} / \mathrm{Mg}(\mathrm{cpx}): \mathrm{Fe} / \mathrm{Mg}(\mathrm{ol})=1.0$; no weighting of elements

cumulation. This process has a much smaller effect on the $\mathrm{Ti}-\mathrm{Zr}$ plot because, in this case, the plagioclase composition lies on a linear backward extrapolation of the fractionation trend, and fractionation and cumulation trends are thus subparallel.

Figures $13 \mathrm{E}$ and $13 \mathrm{~F}$, based on $\mathrm{Sr}$ and $\mathrm{Ni}$, were chosen to investigate the roles of plagioclase and olivine, respectively, during fractional crystallization. On Figure $13 \mathrm{E}$, the main fractionation trend appears to be subhorizontal, although there is also a secondary trend to higher $\mathrm{Sr}$ values, which reflects the effect of plagioclase cumulation. Assuming a plagioclase-liquid distribution coefficient of 1.7 (Philpotts and Schnetzler, 1970), it can be calculated that $55 \%$ plagioclase is needed to explain the observed trend for Hole 597C, a value consistent with the least-squares calculations (Table 5). The trend to high concentrations of $\mathrm{Sr}$ in the ferrobasalts could reflect plagioclase cumulation. On Figure 13F there is a general trend toward lower $\mathrm{Ni}$ with increasing $\mathrm{Zr}$. The proportion of olivine crystallization needed to produce this trend can be calculated, but is very sensitive to the value chosen for the olivine-liquid distribution coefficient for Ni. The coefficient of 10 used in the figure gives a proportion of about $15 \%$; this is nearly double that calculated by the least-squares method, suggesting that a coefficient of 20 may be more appropriate. Figure $13 \mathrm{~F}$ also reveals trends toward high $\mathrm{Ni}$ values for the units containing glomerocrysts (Unit I of Hole 597C and Hole 601B), possible evidence for olivine cumulation.

Trace elements can be further employed to estimate degrees of partial melting and early fractionation histories, using diagrams based on a compatible element (e.g., $\mathrm{Cr}, \mathrm{Ni}$ ) and an incompatible element (e.g., Y, Yb) (Pearce, 1982). On such a diagram, the composition of the mantle source can be estimated, since neither element is greatly affected by source heterogeneities. Moreover, partial melting trends and olivine fractionation trends are almost orthogonal on the relevant part of a diagram of this type, enabling degrees of melting to be determined by back-projection. Figure 14 shows the Ni-Y diagram. The source composition is estimated from nodule compositions. The partial melting trend is based on the melting of a spinel lherzolite composition $(60 \%$ olivine + spinel, $20 \%$ clinopyroxene, $20 \%$ orthopyroxene) in which clinopyroxene disappears after $40 \%$ melting and orthopyroxene disappears after $60 \%$ melting. The olivine + spinel fractionation trend is drawn from the Rayleigh fractionation equation, and fractionation vectors are drawn to enable subsequent multiphase crystallization trends to be interpreted. Distribution coefficients were chosen according to the likely melt temperature, as proposed by Ottonello et al. (1984). It is apparent from this diagram that the various basalt units all plot along fractionation trends that are consistent with the results of the major- 
A
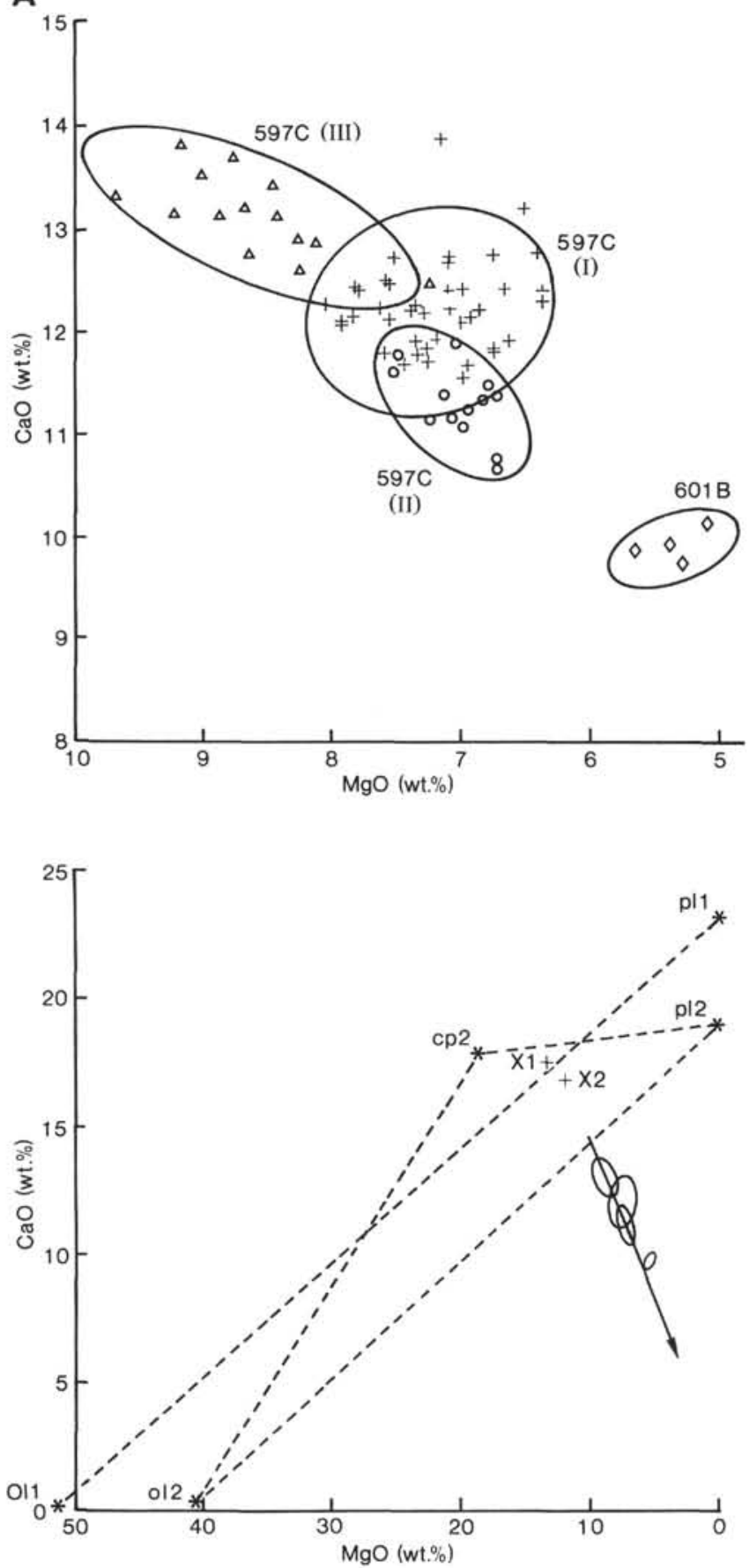

B
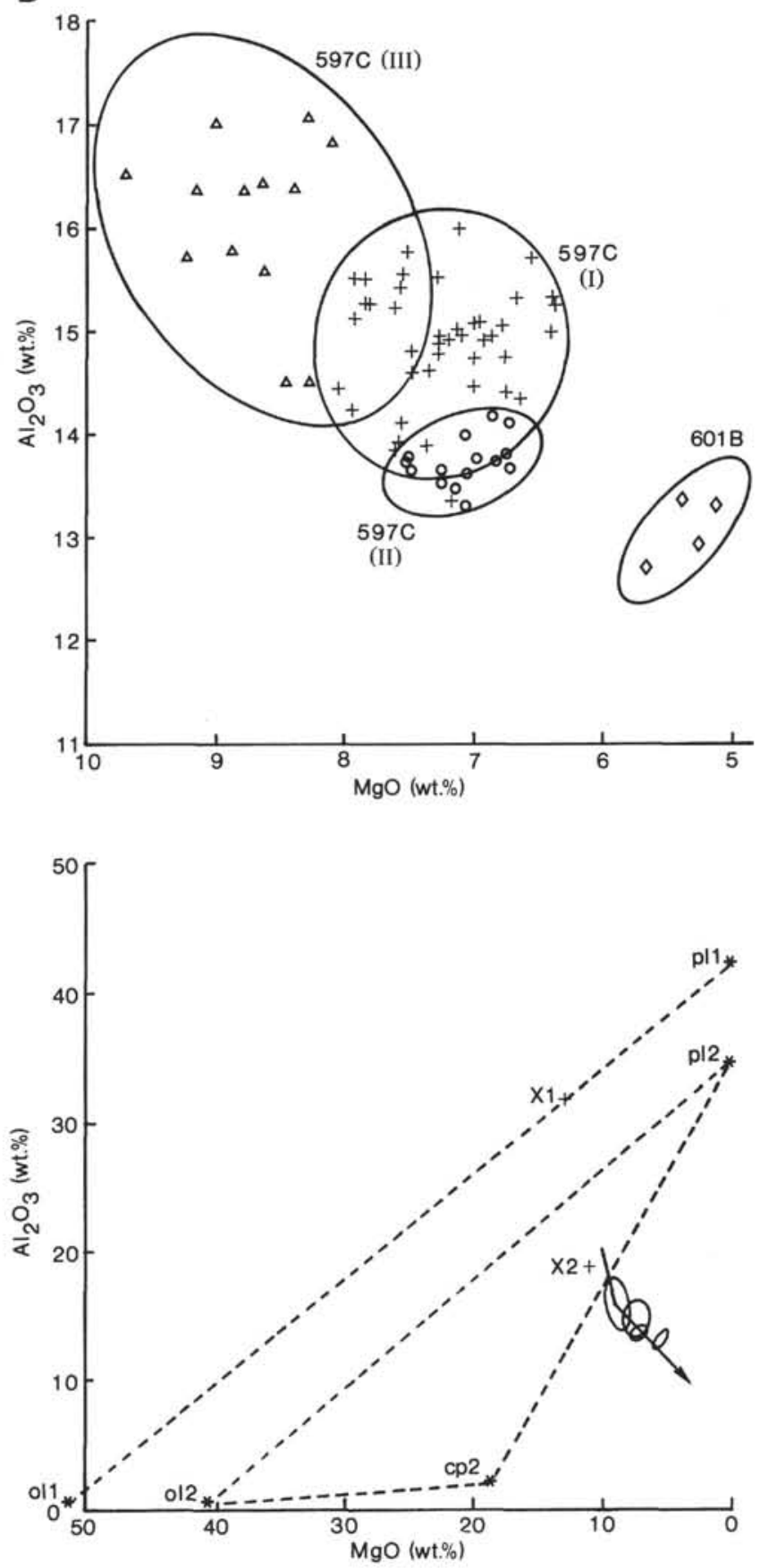

Figure 11. (A) $\mathrm{CaO}-\mathrm{MgO}$, (B) $\mathrm{Al}_{2} \mathrm{O}_{3}-\mathrm{MgO}$, and (C) FeO-MgO covariation diagrams for Hole 597C basalts and Hole 601B ferrobasalts. The upper diagrams show data points and $90 \%$ probability ellipses, the lower diagrams the ellipses and the compositions of the crystallizing phases. The point X1 on the olivine (ol1)-plagioclase (pl1) tie-line represents the likely crystallizing assemblage on the olivine-plagioclase cotectic; the point $\mathrm{X} 2$ within the olivine (ol2)-plagioclase (pl2)-clinopyroxene (cp2) triangle represents the bulk crystallizing assemblage for fractionation from Unit III of Hole 597C to Hole 601B, as calculated by least-squares analysis. Samples from Unit I of Hole 597C are shown by crosses, samples from Unit II of Hole 597C by circles, samples from Unit III of Hole 597C by triangles, and samples from Hole $601 \mathrm{~B}$ by diamonds.

element linear programming. This trend has been continued backward until the estimated point at which the olivine-plagioclase cotectic was reached. Subsequent projection along an olivine vector intersects the partial melting line at between 25 and $30 \%$ melting. Of course, this model does depend on the parameters chosen, but no realistic alternative model deviated greatly from that shown: the general effect of varying the petrogenetic parameters is demonstrated for the $\mathrm{Cr}-\mathrm{Y}$ diagram by Pearce (1982).

\section{GENESIS OF THOLEIITES FROM HOLE 597C}

The geochemical data on Hole $597 \mathrm{C}$ have revealed a surprisingly large downhole variation, all of which can 

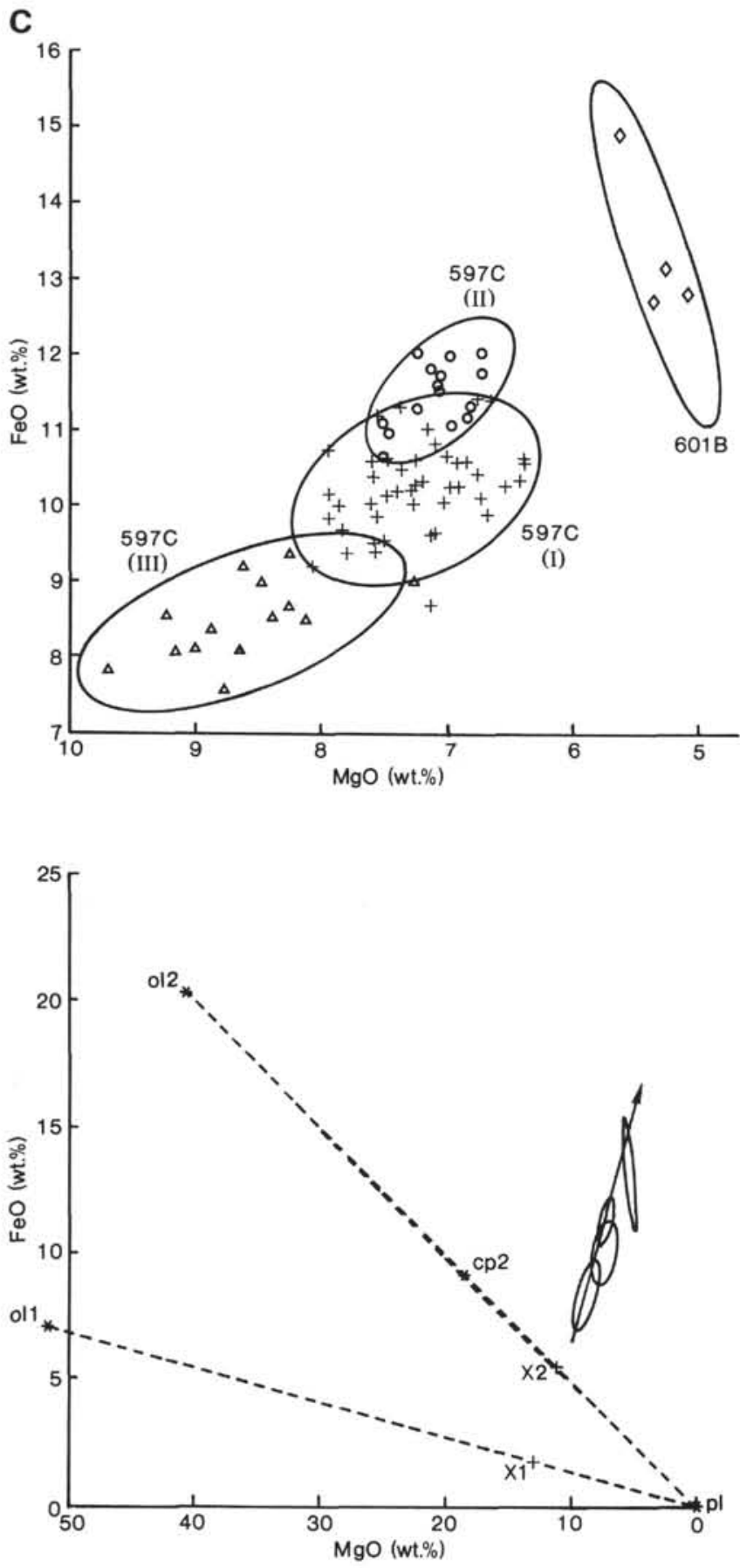

Figure 11 (continued).

be explained in terms of differences in the degree of fractional crystallization. Nonetheless, any attempt to produce a detailed model for the magma-chamber processes operating is greatly constrained by the lack of "field evidence." In particular, we have insufficient information for deciding whether the three units are all lava flows or whether any are sills; we also need more information for deciding whether or not all the units were derived from the same magma chamber. Despite these constraints, however, some interpretations are possible.

The lowermost unit (Unit III) has been shown to be the most basic; the major-element data indicate that on-

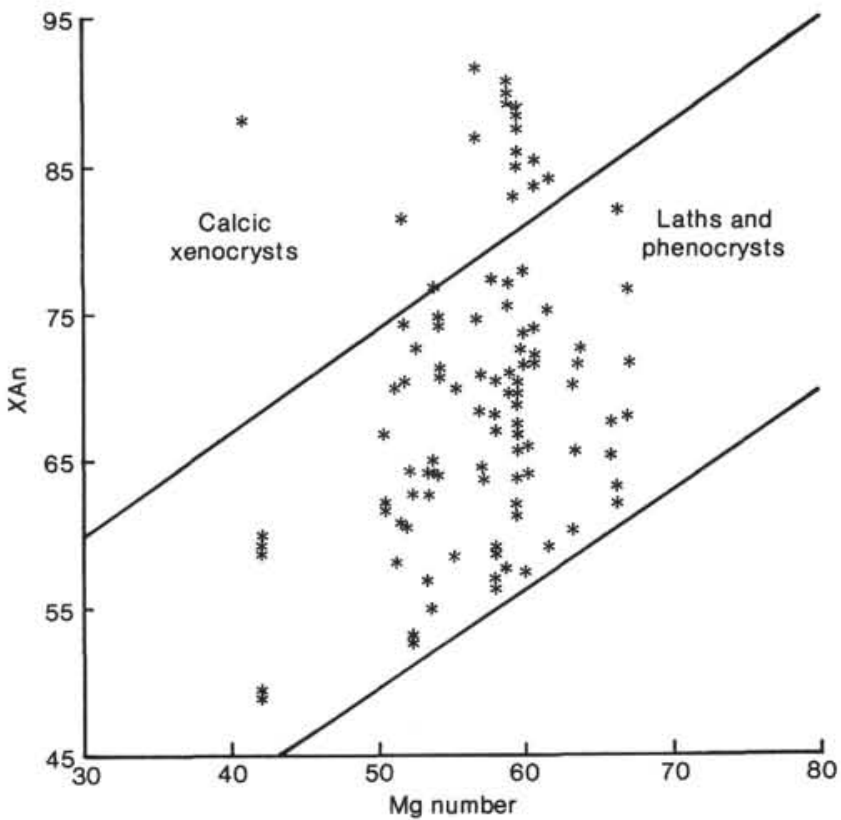

Figure 12. Plot of plagioclase composition against $\mathrm{Mg}$ number of the host rock for tholeiitic basalts from Leg 92 .

ly olivine and plagioclase were liquidus phases when the magma was erupted. It is overlain by the most evolved unit (Unit II), for which olivine, plagioclase, and clinopyroxene were liquidus phases. The geochemical stratigraphy (Fig. 2) shows no sharp boundary, but rather a chemical gradation over some $1.5 \mathrm{~m}$. This latter observation makes it difficult to interpret these units as successive flows. Moreover, extensive fractionation within a single flow by in situ fractionation or olivine cumulation is not supported by the major- or trace-element variations. It is possible, therefore, that the transition zone represents a zone of mixing between two molten, or partially molten, magmas. The ophitic textures that dominate both units, the fine-grained zones that may represent internal cooling zones, and the absence of vesicles, can be cited as further tentative evidence in favor of this hypothesis. If the hypothesis is correct, at least one unit can be thought of as a sheet of magma intruded within a lava lake or pre-existing sill that had not fully crystallized. In addition, the petrogenetic modeling demonstrated that Unit II could be derived from Unit III by 48 to $69 \%$ crystallization. If the two magmas were molten at the same time, then their compositional differences could indicate that they were erupted from separate chambers in different stages of evolution. More realistically, however, they could have been derived from a single chamber in which a more evolved magma was injected by a more basic magma, thus forcing out the evolved magma (Unit II), which was followed by the more primitive magma (Unit III) (Wright and Fiske, 1971; Natland, pers. comm., 1984).

By contrast, the upper unit is distinctive in its content of xenocrysts of calcic plagioclase and (pseudomorphosed) olivine. Thus, although the magma had olivine, plagioclase, and clinopyroxene as liquidus phases, the xenocrysts may provide evidence for an earlier period of mixing with more primitive magma which lay on the oliv- 

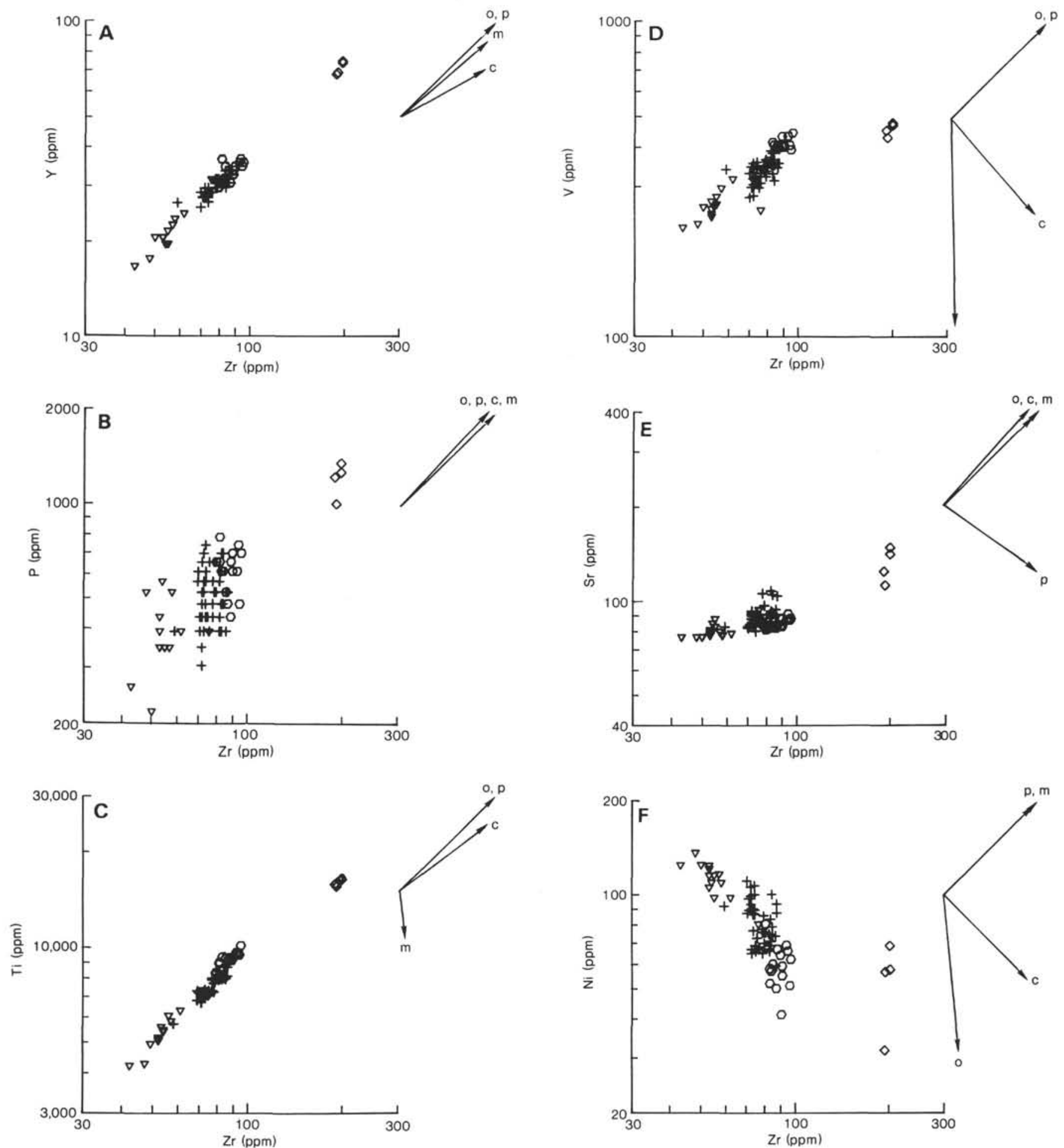

Figure 13. Trace element-Zr covariation diagrams from Hole $597 \mathrm{C}$ and Hole 601 B basalts. A. Y-Zr. B. P-Zr. C. Ti-Zr. D. V-Zr. E. Sr-Zr. F. Ni-Zr. Theoretical fractionation vectors are for $50 \%$ crystallization of single phases, except for magnetite on $\mathrm{Ti}-\mathrm{Zr}$ and $\mathrm{V}-\mathrm{Zr}$ diagrams (5\% crystallization) and for olivine on the $\mathrm{Ni}-\mathrm{Zr}$ diagram ( $10 \%$ crystallization). $\mathrm{o}=$ olivine, $\mathrm{p}=$ plagioclase, $\mathrm{c}=$ clinopyroxene, $\mathrm{m}=$ magnetite. Symbols as for Figure 11.

ine-plagioclase cotectic. In accordance with current ideas on the dynamics of magma chambers (e.g., Sparks et al., 1980), it can be proposed that the xenocrysts were introduced into the superheated upper levels of the magma chamber by upwelling plumes of hotter, more basic magma. When rapid mixing of the two magmas took place, these xenocrysts would have remained suspended in the resultant magma to act as nuclei for further crystallization once the temperature again fell to that of the liquidus. 


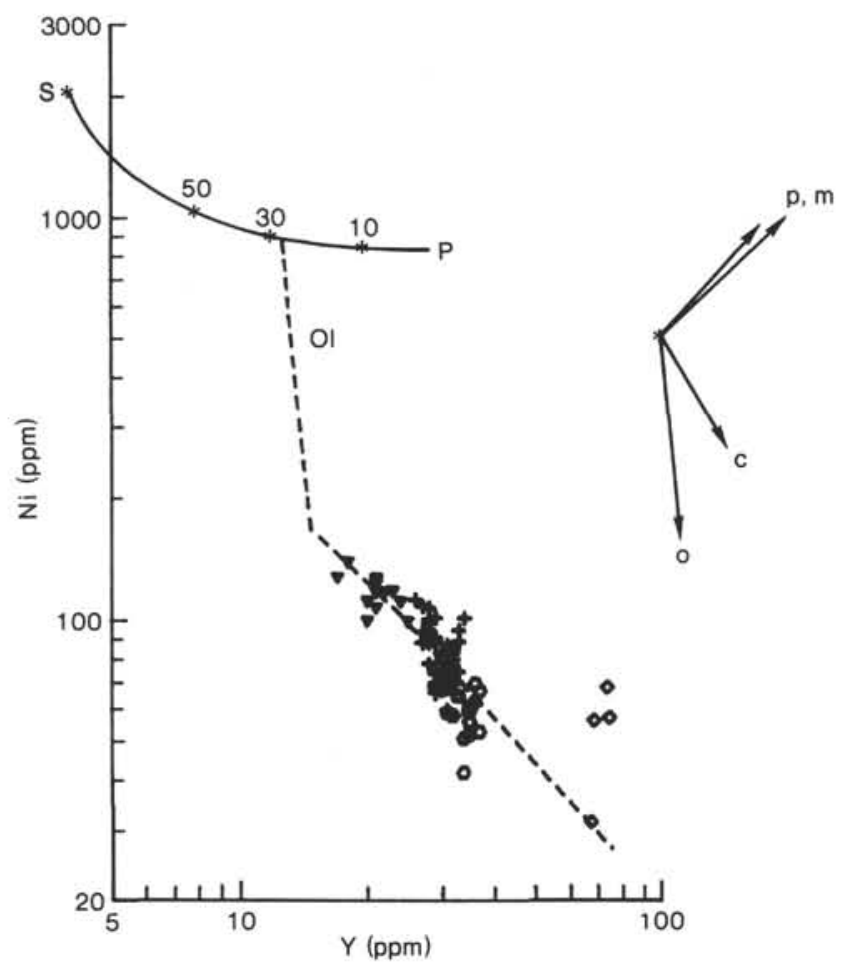

Figure 14. Petrogenetic pathways for Hole 597C and Hole 601B basalts, as illustrated by a Ni-Y diagram. The partial melting trend, annotated for 10,30, and $50 \%$ melting, is given by line $\mathrm{P}$, and the olivine ( + spinel) fractionation trend is shown by the dashed line, Ol. Fractionation vectors appropriate to subsequent crystallization are also shown (cf. Fig. 13F).

On a regional scale, it is interesting that the lavas all closely resemble tholeiites analyzed from other parts of the eastern Pacific, and from the ocean crust in general. This is particularly evident in the shapes of their traceelement patterns (Fig. 15), which show a good correspondence to the pattern (compiled by the authors) for average $\mathrm{N}$-type MORB and thus provide further proof of the uniformity of the MORB reservoir.

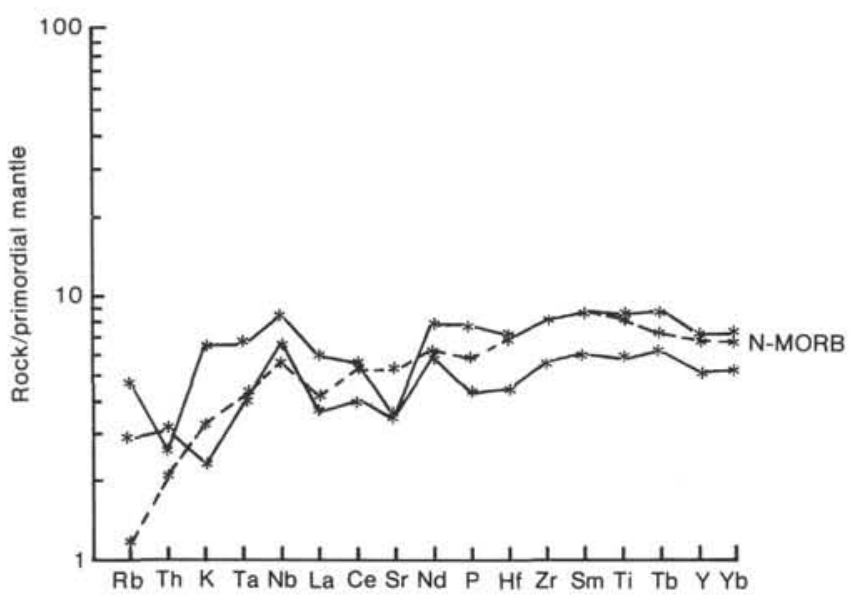

Figure 15. Primordial-mantle-normalized trace-element patterns for the most and least fractionated, "fresh" samples from Hole 597C (solid lines), compared with the pattern of average N-type MORB (dashed line).

\section{GENESIS OF FERROBASALTS FROM HOLE 601B}

The ferrobasalts sampled from Hole 601B represent only a tiny proportion of the rock recovered during Leg 92, but do emphasize the importance of this rock type in the eastern Pacific. One of the most significant petrogenetic features of these lavas is the presence of xenocrysts of calcic plagioclase and pseudomorphosed olivine, which produce cumulation trends on the $\mathrm{Sr}-\mathrm{Zr}$ and $\mathrm{Ni}-\mathrm{Zr}$ diagrams in Figure 13. It is not, however, clear from such limited data whether these were (1) scavenged from solid rock during magma injection, (2) scavenged from the margins of a magma chamber prior to eruption, or (3) introduced into the magma chamber during an episode of mixing with more primitive magma.

Compared with other evolved MORB suites from the eastern Pacific, the ferrobasalts contain less $\mathrm{SiO}_{2}$ than those from the Galapagos Rift, and they are slightly more evolved than those from the Siqueiros Fracture Zone (e.g., Byerly et al., 1976; Natland, 1980). There is insufficient "field" evidence to enable the rocks to be placed into a tectonic framework, or to evaluate models relating ferrobasalts to rift propagation (e.g., Sinton et al., 1983).

\section{GENESIS OF THE ALKALI BASALT FROM HOLE 602B}

The basalt fragment from Hole 602B again constitutes a tiny proportion of the basalts recovered during the leg, but nevertheless emphasizes the importance of the rock type in the region. The genesis of an alkali basalt such as this, although once the subject of debate, can be simply attributed to the melting of incompatibleelement-enriched mantle. The cause of such enrichment is variously explained by enrichment of suboceanic lithosphere resulting from (1) metasomatism by $\mathrm{CO}_{2}$-rich fluids and small-degree melts, (2) melting of enriched convecting upper mantle (mantle plumes), or (3) some form of dynamic melting. Clearly, no distinction between these alternatives can be drawn on the basis of such a small sample. It is worth noting, however, the contrast in enrichment pattern between the alkali basalt sampled and other alkali basalts from the eastern Pacific, as exemplified by the basalt from the Society Islands (Dostal et al., 1982) (Fig. 16). The enrichment in most elements is comparable, but there is a marked difference in the normalized abundances of $\mathrm{Y}$ and $\mathrm{Yb}$. This feature may reflect a genetic difference between E-type MORB and within-plate oceanic alkali basalts, perhaps involving the role of garnet (which retains $\mathrm{Y}$ and $\mathrm{Yb}$ ) in the enrichment or melting process.

\section{SUMMARY}

1. Basement recovery on DSDP Leg 92 consisted primarily of $48.5 \mathrm{~m}$ of core from the $91-\mathrm{m}$ Hole $597 \mathrm{C}$ and $5.4 \mathrm{~m}$ from the 26.4-m "pilot" Hole 597B, both of which were drilled into 28 -Ma crust originally formed at the now-extinct Galapagos Rise. Small quantities of core were also recovered from Holes 597 and 597A (also on Galapagos Rise crust) and Holes 599, 599B, 601B, and 602B (on crust formed at the East Pacific Rise). 


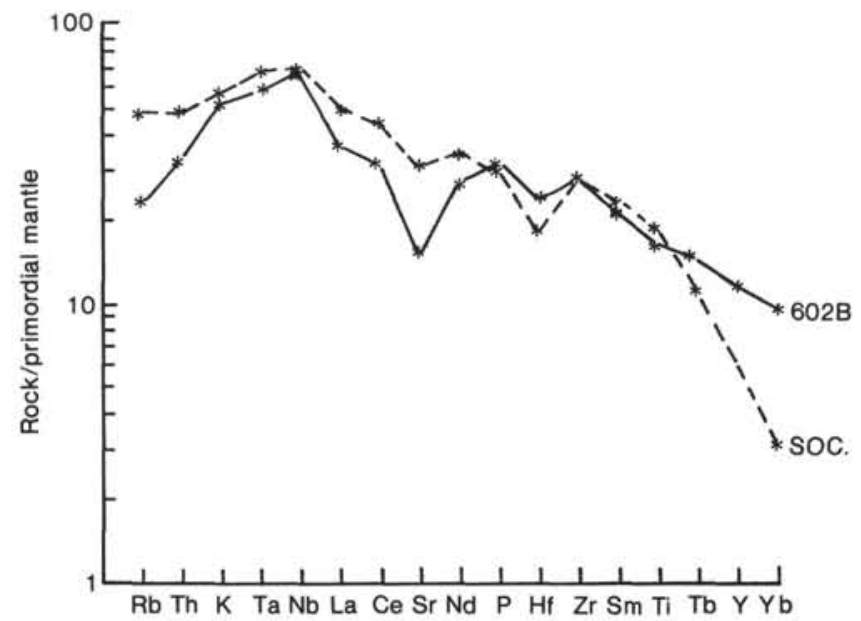

Figure 16. Primordial-mantle-normalized trace-element pattern for the alkali basalt from Hole 601B (solid line), compared with that of an alkali basalt from the Society Islands (SOC.--dashed line).

2. "Conventional" petrologic classification diagrams revealed that all except the basalts from Hole 602B, which proved to be alkalic (Ne-normative), exhibited the ironenrichment trends and hyp-normative characteristics of abyssal tholeiitic basalts; the basalts from Hole 601B additionally had the high $\mathrm{TiO}_{2}$ and $\mathrm{FeO}$ values of ferrobasalts.

3. The "deep" hole, 597C, could be divided petrographically and geochemically into three lithologic units. The lowest unit (Unit III), at least $13 \mathrm{~m}$ thick, is the most basic (containing $>8 \% \mathrm{MgO}$ ) and contains modal olivine. The middle unit (Unit II), about $20 \mathrm{~m}$ thick, is the most evolved and is olivine free. The upper unit, about $48 \mathrm{~m}$ thick, is intermediate in composition and contains both modal olivine and plagioclase glomerocrysts. The upper unit is slightly vesicular, exhibits a range of textures, and was probably a massive flow; the lower units are coarser and nonvesicular and may be massive flows or sills. There is some evidence of a transitional boundary (magma mixing?) between Units II and III.

4. Alteration intensity varies from moderate (in most cores) to very weak (in Units II and III of Hole 597C). The earliest alteration episode (deuteric?) is marked by blue smectite; the two later alteration episodes can be divided into "relatively reducing" (dark green smectite, talc, chlorite, and rare sulfides and native copper) and "relatively oxidizing" (brown smectite, calcite, low-temperature zeolites, and iron oxyhydroxides). Except during replacement of olivine in Unit III of Hole 597, the main chemical effect of alteration is the increase in LOI and in potassium and related elements.

5. Petrogenetic studies show that all basalts except the alkali basalts from Hole 602B were derived from sources of similar composition. In overall terms, the common source was the incompatible-element-depleted reservoir of the convecting upper mantle that is considered the source for all N-type MORB. Other variations can be ascribed primarily to magma-chamber processes. Leastsquares modeling of major elements and graphic modeling of major and trace elements give consistent results in showing that Unit II of Hole $597 \mathrm{C}$ can be derived from Unit III of Hole 597C by about $60 \%$ closed-system crystallization of a bulk assemblage of olivine (about 10\%), plagioclase (about 54\%), and clinopyroxene (about 36\%), and that the ferrobasalts can be derived from Unit III of Hole $597 \mathrm{C}$ by about $80 \%$ closed-system crystallization of a bulk assemblage of olivine (about $9 \%$ ), plagioclase $(51 \%)$, and clinopyroxene $(40 \%)$. They also indicate that clinopyroxene was not a liquidus phase during crystallization of Unit III of Hole 597C. The presence of sometimes partially resorbed or rimmed calcic xenocrysts in both Unit I of Hole 597 and the ferrobasalts provides possible evidence of magma mixing, but the extent of this mixing is difficult to quantify.

6 . The three rock types recovered (primarily MORB tholeiites with rare ferrobasalts and alkali basalts) are all typical of rocks previously recovered by dredging and drilling in the eastern Pacific, although the range of tholeiite compositions in the 91-m hole is surprisingly large.

\section{ACKNOWLEDGMENTS}

J.A.P. would like to thank all participants of Leg 92 for a stimulating experience and for discussions that helped in the preparation of this chapter. We also thank Jim Natland for a constructive review of the manuscript.

\section{REFERENCES}

Anderson, A. T., and Greenland, L. P., 1969. Phosphorus fractionation diagram as a quantitative indicator of crystallization differentiation of basaltic liquid. Geochim. Cosmochim. Acta, 33:493-505.

Basaltic Volcanism Study Project, 1981. Basaltic Volcanism on the Terrestrial Planets: New York (Pergamon Press).

Bass, M. N., 1976. Secondary minerals in oceanic basalt, with special reference to Leg 34, Deep Sea Drilling Project. In Yeats, R. S., Hart, S. R., et al., Init. Repts. DSDP, 34: Washington (U.S. Govt. Printing Office), 393-432.

Byerly, G. R., Melson, W. G., and Vogt, P. R., 1976. Rhyodacites, andesites, ferro-basalts and ocean tholeiites from the Galapagos spreading centre. Earth Planet. Sci. Lett., 30:215-221.

Clague, D. A., Frey, F. A., Thompson, G., and Rindge, S., 1981. Minor and trace element geochemistry of volcanic rocks dredged from the Galapagos spreading center: role of crystal fractionation and mantle heterogeneity. J. Geophys. Res, , 86:9469-9482.

Deer, W. A., Howie, R. A., and Zussman, J., 1966. An introduction to the rock-forming minerals: Harlow, England (Longman).

Dostal, J., Dupuy, C., and Liotard, J. M., 1982. Geochemistry and origin of basaltic lavas from Society Islands, French Polynesia (south central Pacific Ocean). Bull. Volcanol., 45:51-61.

Dungan, M. A., and Rhodes, J. M., 1978. Residual glasses and melt inclusions in basalts from DSDP Legs 45 and 46: evidence for magma mixing. Contrib. Mineral. Petrol., 67:417-431.

Le Bas, M. J., 1962. The role of aluminium in igneous clinopyroxenes with relation to their parentage. Am. J. Sci., 260:267-288.

Mallet, J.-L., 1978. Reconstitution des concentrations minéralogiques à partir des concentrations géochimiques. Sci. Terre, 12:35-64.

Mattey, D. P., and Muir, I. D., 1980. Geochemistry and mineralogy of basalts from the Galapagos spreading center, Deep Sea Drilling Project Leg 54. In Rosendahl, B. R., Hekinian, R., et al., Init. Repts. DSDP, 54: Washington (U.S. Govt. Printing Office), 755771.

Mazzullo, L. J., and Bence, A. E., 1976. Abyssal tholeiites from DSDP Leg 34: the Nazca Plate. J. Geophys. Res., 81:4327-4351.

Muir, I. D., and Mattey, D. A., 1982. Pyroxene fractionation in ferrobasalts from the Galapagos spreading centre. Min. Mag., 45: 193-200.

Nakamura, N., 1974. Determination of REE, Ba, Fe, Mg, Na and $\mathrm{K}$ in carbonaceous and ordinary meteorites. Geochim. Cosmochim. Acta, 38:757-775.

Natland, J. H., 1980. Effect of axial magma chambers beneath spreading centers on the compositions of basaltic rocks. In Rosendahl, B. 
R., Hekinian, R., et al., Init. Repts. DSDP, 54: Washington (U.S. Govt. Printing Office), 833-850.

Natland, J. H., Adamson, A. C., Laverne, C., Melson, W. G., and O'Hearn, T., 1983. A compositionally nearly steady-state magma chamber at the Costa Rica Rift: evidence from basalt glass and mineral data, Deep Sea Drilling Project Sites 501, 504, and 505. In Cann, J. R., Langseth, M. G., Honnorez, J., Von Herzen, R. P., White, S. M., et al., Init. Repts. DSDP, 69: Washington (U.S. Govt. Printing Office), 811-858.

O'Hara, M. J., 1977. Geochemical evolution during fractional crystallization of a periodically refilled magma chamber. Nature, 266: 503-507.

Osborn, E. F., and Tait, D. B., 1952. The system diopside-forsteriteanorthite. Am. J. Sci. (Bowen Volume), 413-433.

Ottonello, G., Ernst, W. G., and Joron, J. L., 1984. Rare earth and 3d transition element geochemistry of peridotitic rocks: I. Periodotites from the western Alps. J. Petrol., 25:343-372.

Paul, D. K., Potts, P. J., Gibson, I. L., and Harris, P. G., 1975. Rare earth abundances in Indian kimberlite. Earth Planet. Sci. Lett., 25:151-158.

Pearce, J. A., 1982. Trace element characteristics of lavas from destructive plate boundaries. In Thorpe, R. S. (Ed.), Andesites: New York (John Wiley and Sons), pp. 525-548.

Pearce, J. A., and Norry, M. J., 1979. Petrogenetic implications of Ti, $\mathrm{Zr}, \mathrm{Y}$ and $\mathrm{Nb}$ variations in volcanic rocks. Contrib. Mineral. Petrol., 69:33-47.

Perfit, M. R., Fornari, D. J., Malahoff, A., and Embley, R. W., 1983. Geochemical studies of abyssal lavas recovered by DSRV Alvin from Eastern Galapagos Rift, Inca Transform, and Ecuador Rift. 3. Trace element abundances and petrogenesis. J. Geophys. Res., 88: $10,551-10,572$

Philpotts, J. A., and Schnetzler, C. C., 1970. Phenocryst-matrix partition coefficients for $\mathrm{K}, \mathrm{Rb}, \mathrm{Sr}$ and $\mathrm{Ba}$ with application to anorthosite and basalt genesis. Geochim. Cosmochim. Acta, 34:331340.

Potts, P. J., Thorpe, O. W., and Watson, J. S., 1981. Determination of rare-earth element abundances in 29 international rock standards by instrumental neutron activation analysis: a critical appraisal of calibration errors. Chem. Geol., 34:331-352.

Potts, P. J., Webb, P. C., and Watson, J. S., 1984. Energy-dispersive $\mathrm{X}$-ray fluorescence analysis of silicate rocks for major and trace elements. X-Ray Spectrom., 13:2-15.
Rea, D.K., 1981. Tectonics of the Nazca-Pacific divergent plate boundary. Mem. Geol. Soc. Am., 154:27-62.

Scheidegger, K. F., and Corliss, J. B., 1981. Petrogenesis and secondary alteration of upper Layer 2 basalts of the Nazca Plate. Mem. Geol. Soc. Am., 154:77-107.

Shido, F., Miyashiro, A., and Ewing, M., 1971. Crystallization of abyssal tholeiites. Contrib. Mineral. Petrol., 31:251-266.

Sinton, J. M., Wilson, D. S., Christie, D. M., Hey, R. N., and Delaney, J. R., 1983. Petrologic consequences of rift propagation on oceanic spreading ridges. Earth Planet. Sci. Lett., 62:193-207.

Sparks, R. S. J., Meyer, P., and Sigurdsson, H., 1980. Density variation amongst mid-ocean ridge basalts: implications for magma mixing and the scarcity of primitive lavas. Earth Planet. Sci. Lett., 46:419-430.

Stakes, D. S., Shervais, J. W., and Hopson, C. A., 1984. The volcanotectonic cycle of the FAMOUS and AMAR valleys, Mid-Atlantic Ridge $\left(36^{\circ} 47^{\prime} \mathrm{N}\right)$ : evidence from basalt glass and phenocryst compositional variations for a steady-state magma chamber beneath the valley midsections. J. Geophys. Res., 89:6995-7028.

Tarney, J., Wood, D. A., Saunders, A. D., Cann, J. R., and Varet, J., 1980. Nature of mantle heterogeneity in the North Atlantic: evidence from deep sea drilling. Phil. Trans. R. Soc. London, A297: 179-202.

Wood, D. A., 1979. A variably veined suboceanic upper mantle-genetic significance for mid-ocean basalts from geochemical evidence. Geology, 7:499-503.

Wright, T. L., 1974. Presentation and interpretation of chemical data for igneous rocks. Contrib. Mineral. Petrol., 48:233-248.

Wright, T. L., and Doherty, P. C., 1970. A linear programming and least squares computer method for solving petrologic mixing problems. Geol. Soc. Am. Bull., 81:1995-2008.

Wright, T. L., and Fiske, R. S., 1971. Origin of the differentiated and hybrid lavas of Kilauea Volcano, Hawaii. J. Petrol., 12:1-65.

Yeats, R. S., Hart, S. R., et al., 1976. Init. Repts. DSDP, 34: Washington (U.S. Govt. Printing Office).

Yoder, H. S., and Tilley, C. E., 1962. Origin of basalt magmas: an experimental study of natural and synthetic rock systems. J. Petrol., $3: 342-532$.

Date of Initial Receipt: 11 October 1984

Date of Acceptance: 15 May 1985

APPENDIX A

Geochemical Data on Some USGS Standard Rocks (BCR1, AGV1, GSP1, and a DSDP Leg 92 Standard, ILB1)

\begin{tabular}{|c|c|c|c|c|c|c|c|}
\hline Std. & $\begin{array}{c}\text { BCR1 } \\
\text { Observed } \\
\text { Mean (s.d.) }\end{array}$ & $\begin{array}{c}\text { BCR1 } \\
\text { Recommended } \\
\text { Mean (s.d.) }\end{array}$ & $\begin{array}{c}\text { AGV1 } \\
\text { Observed } \\
\text { Mean (s.d.) }\end{array}$ & $\begin{array}{c}\text { AGV1 } \\
\text { Recommended } \\
\text { Mean (s.d.) }\end{array}$ & $\begin{array}{c}\text { GSP1 } \\
\text { Observed } \\
\text { Mean (s.d.) }\end{array}$ & $\begin{array}{c}\text { GSP1 } \\
\text { Recommended } \\
\text { Mean (s.d.) }\end{array}$ & $\begin{array}{c}\text { ILB1 } \\
\text { Observed } \\
\text { Mean (s.d.) }\end{array}$ \\
\hline $\mathrm{SiO}_{2}$ & $54.84(0.38)$ & $54.35(0.51)$ & $59.69(0.11)$ & $59.25(0.58)$ & $67.54(0.09)$ & $67.37(0.49)$ & $49.77(0.26)$ \\
\hline $\mathrm{TiO}_{2}^{2}$ & $2.24(0.02)$ & $2.22(0.10)$ & $1.07(0.01)$ & $1.06(0.05)$ & $0.67(0.00)$ & $0.66(0.04)$ & $1.32(0.01)$ \\
\hline $\mathrm{Al}_{2} \mathrm{O}_{3}$ & $13.59(0.18)$ & $13.63(0.25)$ & $17.11(0.14)$ & $17.15(0.34)$ & $15.24(0.10)$ & $15.16(0.28)$ & $14.60(0.19)$ \\
\hline $\mathrm{Fe}_{2} \mathrm{O}_{3}$ & $13.31(0.09)$ & $13.41(0.31)$ & $7.03(0.01)$ & $6.77(0.19)$ & $4.47(0.01)$ & $4.30(0.13)$ & $11.62(0.05)$ \\
\hline $\mathrm{MnO}^{3}$ & $0.19(0.01)$ & $0.18(0.01)$ & $0.10(0.00)$ & $0.10(0.01)$ & $0.04(0.00)$ & $0.04(0.01)$ & $0.16(0.00)$ \\
\hline $\mathrm{MgO}$ & $3.56(0.12)$ & $3.45(0.17)$ & $1.57(0.12)$ & $1.53(0.10)$ & $0.97(0.08)$ & $0.99(0.08)$ & $7.40(0.14)$ \\
\hline $\mathrm{CaO}$ & $7.05(0.06)$ & $6.95(0.15)$ & $5.09(0.01)$ & $4.94(0.14)$ & $2.02(0.00)$ & $2.04(0.10)$ & $11.78(0.06)$ \\
\hline $\mathrm{Na}_{2} \mathrm{O}$ & $3.36(0.30)$ & $3.27(0.11)$ & $4.19(0.24)$ & $4.25(0.12)$ & $2.63(0.17)$ & $2.80(0.09)$ & $2.39(0.30)$ \\
\hline $\mathrm{K}_{2} \mathrm{O}$ & $1.66(0.04)$ & $1.69(0.08)$ & $2.94(0.01)$ & $2.90(0.10)$ & $5.61(0.02)$ & $5.51(0.14)$ & $0.09(0.01)$ \\
\hline $\mathrm{P}_{2} \mathrm{O}_{5}$ & $0.36(0.02)$ & $0.37(0.02)$ & $0.51(0.03)$ & $0.44(0.03)$ & $0.28(0.01)$ & $0.28(0.02)$ & $0.13(0.03)$ \\
\hline $\mathrm{Zr}$ & $184(1.9)$ & $191(5)$ & $238(0)$ & $225(18)$ & $498(2.4)$ & $530(70)$ & $79(0.7)$ \\
\hline $\mathrm{Y}$ & $37(0.4)$ & 39 (7) & $21(0)$ & $21(6)$ & $29(0.5)$ & $29(6)$ & $31(0.4)$ \\
\hline $\mathrm{Nb}$ & $11.8(0.2)$ & 14.0 & $14.6(0)$ & $15.0(3)$ & $14.4(0.5)$ & 26.0 (4) & $4.5(0.3)$ \\
\hline $\mathbf{R b}$ & $49(0.4)$ & 47 (1) & $70(0)$ & 67 (1) & $151(2.1)$ & 254 (2) & $3(0.3)$ \\
\hline $\mathrm{Sr}$ & $322(0.4)$ & $330(5)$ & $0(0)$ & $662(9)$ & 233 (1.5) & 234 (3) & $87(0.8)$ \\
\hline $\mathrm{Cr}$ & $12(3)$ & $16(4)$ & $18(0)$ & $12(3)$ & $11(3)$ & $13(3)$ & $215(10)$ \\
\hline $\mathrm{Ni}$ & $14(1.1)$ & $13(4)$ & $123(0)$ & $17(4)$ & 9 (2.6) & $10(3)$ & $78(9.0)$ \\
\hline V & 387 (29) & $404(40)$ & $64(0)$ & 123 (12) & $62(9)$ & $53(7)$ & $346(16)$ \\
\hline $\mathrm{Cu}$ & $19(1.5)$ & $19(4)$ & $88(0)$ & $60(6)$ & $34(1.7)$ & 34 (5) & $121(4.2)$ \\
\hline $\mathrm{Zn}$ & $121(2.2)$ & 129 (1) & $20(0)$ & 88 (2) & $103(2.4)$ & $103(9)$ & $89(0.6)$ \\
\hline
\end{tabular}

Note: Number of analyses: BCR1 (majors = 12, traces = 3); AGV1 (majors = 37, traces = 1); GSP1 (majors =6, traces = 19); ILB1 (majors $=7$, traces $=5$ ). Zero signifies no data available. Total iron expressed as $\mathrm{Fe}_{2} \mathrm{O}_{3}$. s.d. $=$ standard deviation. 
APPENDIX B

Major-Element Data, XRF Trace-Element Data, and CIPW Norms for DSDP Leg 92 Basalts

\begin{tabular}{|c|c|c|c|c|c|c|c|c|c|c|c|c|c|c|c|c|c|c|c|c|}
\hline $\begin{array}{l}\text { Hole } \\
\text { Core-Sec. } \\
\text { Position, cm }\end{array}$ & $\begin{array}{c}597 \\
8, C C\end{array}$ & $\begin{array}{c}5978 \\
2-1 \\
7\end{array}$ & $\begin{array}{l}597 \mathrm{~B} \\
2-1 \\
36\end{array}$ & $\begin{array}{l}597 \mathrm{~B} \\
2-1 \\
55\end{array}$ & $\begin{array}{c}597 \mathrm{~B} \\
2-1 \\
66\end{array}$ & $\begin{array}{l}5978 \\
2.2 \\
138\end{array}$ & $\begin{array}{l}5978 \\
2-3 \\
25\end{array}$ & $\begin{array}{c}5978 \\
2-3 \\
63\end{array}$ & $\begin{array}{l}597 \mathrm{~B} \\
2-3 \\
110\end{array}$ & $\begin{array}{c}5978 \\
3-1 \\
16\end{array}$ & $\begin{array}{c}5978 \\
3-1 \\
75\end{array}$ & $\begin{array}{c}5978 \\
3 \cdot 1 \\
141\end{array}$ & $\begin{array}{l}5978 \\
3-2 \\
27\end{array}$ & $\begin{array}{c}597 \mathrm{~B} \\
3-2 \\
51\end{array}$ & $\begin{array}{c}5978 \\
3 \cdot 2 \\
56\end{array}$ & $\begin{array}{c}597 \mathrm{C} \\
3-1 \\
3\end{array}$ & $\begin{array}{c}597 \mathrm{C} \\
3-1 \\
52\end{array}$ & $\begin{array}{c}597 \mathrm{C} \\
3-2 \\
20\end{array}$ & $\begin{array}{c}597 \mathrm{C} \\
3-2 \\
117\end{array}$ & $\begin{array}{c}597 \mathrm{C} \\
3.3 \\
9\end{array}$ \\
\hline $\mathrm{SiO}_{2}$ & 49.34 & 50.17 & 48.61 & 49.74 & 49.97 & 50.00 & 50.44 & 50.11 & 49.37 & 50.08 & 48.72 & 49.74 & 50.10 & 50.14 & 51.10 & 48.53 & 49.68 & 49.86 & 49.40 & 50.17 \\
\hline $\mathrm{TiO}_{2}$ & 1.04 & 1.00 & 1.06 & 1.08 & 1.11 & 1.23 & 1.28 & 1.33 & 1.27 & 1.35 & 1.24 & 1.24 & 1.22 & 1.20 & 1.20 & 0.95 & 1.13 & 1.20 & 1.20 & 1.32 \\
\hline $\mathrm{Al}_{2} \mathrm{O}_{3}$ & 15.18 & 14.47 & 15.47 & 14.69 & 14.83 & 15.07 & 15.21 & 15.29 & 13.72 & 14.81 & 14.04 & 15.09 & 14.60 & 15.21 & 15.06 & 15.70 & 14.44 & 15.26 & 14.40 & 15.01 \\
\hline $\mathrm{Fe}_{2} \mathrm{O}_{3}$ & 11.14 & 10.26 & 9.40 & 10.63 & 10.20 & 10.24 & 9.83 & 10.23 & 13.18 & 11.29 & 12.89 & 10.98 & 10.52 & 11.27 & 9.97 & 11.36 & 10.19 & 10.41 & 12.69 & 10.67 \\
\hline $\mathrm{MnO}^{\circ}$ & 0.18 & 0.15 & 0.14 & 0.16 & 0.16 & 0.15 & 0.15 & 0.16 & 0.16 & 0.15 & 0.15 & 0.15 & 0.15 & 0.17 & 0.17 & 0.19 & 0.16 & 0.15 & 0.15 & 0.17 \\
\hline $\mathrm{MgO}$ & 7.54 & 8.85 & 7.75 & 8.12 & 7.86 & 7.44 & 7.48 & 7.12 & 6.37 & 7,44 & 6.19 & 6.97 & 7.20 & 7.80 & 6.84 & 6.54 & 8.05 & 7.81 & 6.75 & 7.12 \\
\hline $\mathrm{CaO}$ & 12.99 & 12.36 & 13.71 & 12.73 & 12.51 & 12.26 & 12.27 & 12.66 & 11.29 & 11.97 & 11.52 & 12.36 & 12.41 & 12.02 & 12.72 & 13.16 & 12.24 & 12.40 & 11.77 & 12.38 \\
\hline $\mathrm{Na}_{2} \mathrm{O}$ & 2.54 & 2.21 & 2.24 & 2.64 & 2.28 & 2.23 & 2.52 & 2.20 & 2.39 & 2.42 & 2.26 & 2.59 & 1.97 & 2.29 & 2.78 & 1.87 & 2.02 & 2.13 & 2.23 & 2.78 \\
\hline $\mathrm{K}_{2} \mathrm{O}$ & 0.32 & 0.15 & 0.29 & 0.22 & 0.22 & 0.10 & 0.22 & 0.29 & 1.21 & 0.10 & 1.12 & 0.56 & 0.11 & 0.09 & 0.23 & 0.31 & 0.15 & 0.10 & 1.02 & 0.48 \\
\hline $\mathrm{P}_{2} \mathrm{O}_{5}$ & 0.15 & 0.10 & 0.11 & 0.12 & 0.10 & 0.14 & 0.10 & 0.13 & 0.14 & 0.12 & 0.14 & 0.12 & 0.16 & 0.10 & 0.15 & 0.09 & 0.13 & 0.16 & 0.12 & 0.16 \\
\hline Lô & 0.51 & 0.73 & 2.47 & 0.52 & 0.83 & 0.40 & 0.50 & 0.52 & 0.99 & 0.15 & 0.72 & 0.64 & 0.32 & 0.61 & 0.23 & 0.55 & 0.69 & 0.47 & 0.52 & 0.60 \\
\hline Total & 100.93 & 100.45 & 101.25 & 100.65 & 100.07 & 99.26 & 100.00 & 100.04 & 100.09 & 99.88 & 98.99 & 100.44 & 98.76 & 100.90 & 100.45 & 99.25 & 98.88 & 99.95 & 100.25 & 100.86 \\
\hline $\mathrm{Zr}$ & 64 & 60 & 67 & 67 & 71 & 78 & 83 & 85 & 84 & 83 & 80 & 79 & 76 & 71 & 76 & 59 & 70 & 73 & 79 & 84 \\
\hline$Y$ & 29 & 25 & 27 & 27 & 28 & 29 & 32 & 33 & 31 & 31 & 32 & 33 & 31 & 27 & 33 & 27 & 26 & 28 & 31 & 32 \\
\hline $\mathrm{Nb}$ & 2.7 & 3.6 & 3.5 & 4.1 & 4.2 & 4.6 & 3.9 & 5.0 & 4.0 & 4.3 & 4.5 & 5.1 & 4.1 & 3.9 & 2.0 & 4,1 & 3.7 & 4.7 & 4.7 & 4.1 \\
\hline $\mathrm{Rb}$ & 7.0 & 3.1 & 5.6 & 4.7 & 5.5 & 3.0 & 9.3 & 12.3 & 37.6 & 3.0 & 27.9 & 18.6 & 2.5 & 2.6 & 8.5 & 3.9 & 4.3 & 3.4 & 24.8 & 13.4 \\
\hline $\mathrm{Sr}$ & 84 & 79 & 94 & 85 & 86 & 90 & 99 & 106 & 94 & 92 & 89 & 103 & 92 & 82 & 92 & 83 & 83 & 88 & 82 & 105 \\
\hline $\mathrm{Cr}$ & 363 & 351 & 273 & 334 & 324 & 252 & 261 & 267 & 223 & 191 & 188 & 262 & 278 & 253 & 261 & 395 & 312 & 241 & 220 & 234 \\
\hline $\mathrm{Ni}$ & 94 & 171 & 130 & 127 & 147 & 150 & 149 & 72 & 65 & 80 & 54 & 90 & 151 & 94 & 71 & 94 & 113 & 88 & 87 & 80 \\
\hline $\mathrm{v}$ & 321 & 284 & 298 & 332 & 315 & 333 & 352 & 345 & 308 & 361 & 351 & 318 & 342 & 324 & 284 & 341 & 277 & 322 & 323 & 313 \\
\hline $\mathrm{Cu}$ & 131 & 129 & 130 & 123 & 132 & 129 & 141 & 198 & 130 & 130 & 86 & 117 & 124 & 120 & 107 & 125 & 124 & 112 & 121 & 155 \\
\hline $\mathrm{Zn}$ & 107 & 82 & 82 & 81 & 84 & 82 & 91 & 98 & 91 & 89 & 71 & 88 & 89 & 76 & 80 & 91 & 74 & 78 & 74 & 88 \\
\hline Q & 0.00 & 0.00 & 0.00 & 0.00 & 0.00 & 0.79 & 0.00 & 0.42 & 0.00 & 0.00 & 0.00 & 0.00 & 2.45 & 0.00 & 0.00 & 0.00 & 0.74 & 0.23 & 0.00 & 0.00 \\
\hline Or & 1.89 & 1.89 & 1.71 & 1.30 & 1.30 & 0.59 & 1.30 & 1.71 & 7.15 & 0.59 & 6.62 & 3.31 & 0.65 & 0.53 & 1.36 & 1.83 & 0.89 & 0.59 & 6.03 & 2.84 \\
\hline$A b$ & 21.49 & 18.70 & 18.95 & 22.34 & 19.29 & 18.87 & 21.32 & 18.62 & 20.22 & 20.48 & 19.12 & 21.92 & 16.67 & 19.38 & 23.52 & 15.82 & 17.09 & 18.02 & 18.87 & 23.52 \\
\hline An & 29.08 & 29.13 & 31.31 & 27.59 & 29.59 & 30.82 & 29.55 & 31.00 & 23.14 & 29.26 & 24.86 & 27.90 & 30.68 & 30.96 & 27,94 & 33.54 & 29.90 & 31.79 & 26.28 & 27.07 \\
\hline $\mathrm{Ne}$ & 0.00 & 0.00 & 0.00 & 0.00 & 0.00 & 0.00 & 0.00 & 0.00 & 0.00 & 0.00 & 0.00 & 0.00 & 0.00 & 0.00 & 0.00 & 0.00 & 0.00 & 0.00 & 0.00 & 0.00 \\
\hline $\mathrm{Di}_{\mathrm{i}}$ & 28.10 & 25.58 & 29.21 & 28.31 & 25.89 & 23.69 & 24.93 & 25.24 & 26.39 & 23.97 & 25.92 & 26.70 & 24.36 & 22.86 & 27.89 & 25.61 & 24.36 & 23.34 & 25.80 & 27.19 \\
\hline $\mathrm{Hy}$ & 4.03 & 17.01 & 4.05 & 5.67 & 15.74 & 18.34 & 15.44 & 16.62 & 8.73 & 18.80 & 9.14 & 7.10 & 17.77 & 19.58 & 12.10 & 14.88 & 19.68 & 19.71 & 10.08 & 6.24 \\
\hline ol & 10.13 & 3.17 & 8.43 & 9.38 & 2.00 & 0.00 & 1.31 & 0.00 & 6.73 & 0.37 & 6.03 & 6.92 & 0.00 & 1.05 & 1.76 & 1.56 & 0.00 & 0.00 & 6.28 & 7.30 \\
\hline $\mathrm{Mt}$ & 2.42 & 2.23 & 2.04 & 2.31 & 2.22 & 2.23 & 2.14 & 2.22 & 2.87 & 2.46 & 2.80 & 2.39 & 2.29 & 2.45 & 2.17 & 2.47 & 2.22 & 2.26 & 2.76 & 2.32 \\
\hline II & 1.98 & 1.90 & 2.01 & 2.05 & 2.11 & 2.34 & 2.43 & 2.53 & 2.41 & 2.56 & 2.36 & 2.36 & 2.32 & 2.28 & 2.28 & 1.80 & 2.15 & 2.28 & 2.28 & 2.51 \\
\hline AD & 0.35 & 0.23 & 0.25 & 0.28 & 0.23 & 0.32 & 0.23 & 0.30 & 0.32 & 0.28 & 0.32 & 0.28 & 0.37 & 0.23 & 0.35 & 0.21 & 0.30 & 0.37 & 0.28 & 0.37 \\
\hline
\end{tabular}

Note: Total iron has been expressed as $\mathrm{Fe}_{2} \mathrm{O}_{3}$ in the oxide columns. Norm calculations assume $\mathrm{Fe}^{2} /\left(\mathrm{Fe}^{2}+\mathrm{Fe}^{3}\right)=0.85$. Nondetermined $\mathrm{Cr}$ and $\mathrm{V}$ are given as 0 . "Position" row gives upper sampling position of minicore of $2 \mathrm{~cm}$ diameter.

APPENDIX C

Reconnaissance Electron Microprobe Analyses (wt.\%) of Pyroxenes from DSDP Leg 92 Basalts

\begin{tabular}{|c|c|c|c|c|c|c|c|c|c|c|c|c|c|c|c|c|c|c|c|c|c|c|}
\hline Hole & $597 \mathrm{~B}$ & $597 \mathrm{~B}$ & 5978 & 597B & $597 \mathrm{~B}$ & 597B & 5978 & $597 \mathrm{~B}$ & $597 \mathrm{~B}$ & $597 \mathrm{~B}$ & 5978 & 5978 & $597 \mathrm{~B}$ & 597B & 597B & $597 \mathrm{~B}$ & $597 \mathrm{C}$ & $597 \mathrm{C}$ & $597 \mathrm{C}$ & $597 \mathrm{C}$ & $597 \mathrm{C}$ & $597 \mathrm{C}$ \\
\hline Core-Sec. & $2-2$ & $2-2$ & $3-1$ & $3-1$ & $3-1$ & $3-1$ & $3-1$ & $3=1$ & $3-2$ & $3-2$ & $3-2$ & $3-2$ & $3-2$ & 3.2 & $3-2$ & $3-2$ & 3.2 & $3-2$ & 3.2 & $3-2$ & $3-2$ & 3.2 \\
\hline Position, cm & 138 & 138 & 16 & 16 & 16 & 16 & 16 & 16 & 27 & 27 & 27 & 27 & 27 & 27 & 56 & 56 & 20 & 20 & 20 & 117 & 117 & 117 \\
\hline Petrology $y^{\mathrm{a}}$ & $\mathrm{v}$ & $\mathrm{v}$ & $\mathrm{P}$ & $\mathbf{P}$ & $\mathrm{P}$ & $\mathbf{P}$ & P & P & $\mathrm{P}$ & P & $\mathrm{p}$ & $\mathrm{p}$ & P & $\mathrm{P}$ & 1 & 1 & $\mathbf{P}$ & P & P & 1 & 1 & P \\
\hline $\mathrm{SiO}_{2}$ & 51.07 & 51.20 & 50.93 & 51.75 & 52.67 & 52.25 & 49.67 & 50.54 & 50.57 & 50.71 & 48.78 & 52.47 & 50.91 & 50.46 & 50.16 & 50.78 & 50.74 & 50.82 & 51.13 & 51.71 & 51.35 & 53.36 \\
\hline $\mathrm{TiO}_{2}$ & 0.93 & 0.75 & 0.97 & 0.77 & 0.63 & 0.41 & 1.40 & 1.01 & 0.98 & 0.91 & 0.87 & 0.60 & 0.81 & 0.82 & 1.13 & 0.81 & 0.84 & 0.97 & 0.77 & 0.75 & 0.80 & 0.58 \\
\hline $\mathrm{Al}_{2} \mathrm{O}_{3}$ & 3.66 & 3.58 & 3.62 & 2.81 & 2.21 & 2.50 & 3.25 & 2.52 & 2.75 & 1.83 & 1.44 & 2.75 & 2.41 & 2.26 & 3.81 & 4.35 & 3.33 & 4.06 & 3.97 & 3.25 & 3.04 & 2.08 \\
\hline $\mathrm{FeO}$ & 8.98 & 7.97 & 9.05 & 8.81 & 9.06 & 5.39 & 15.17 & 16.21 & 11.96 & 19.25 & 23.03 & 7.38 & 13.15 & 16.09 & 12.61 & 6.91 & 8.67 & 8.53 & 6.68 & 9.47 & 9.34 & 8.60 \\
\hline $\mathrm{MnO}$ & 0.20 & 0.24 & 0.20 & 0.23 & 0.25 & 0.16 & 0.39 & 0.40 & 0.30 & 0.52 & 0.63 & 0.20 & 0.31 & 0.42 & 0.31 & 0.20 & 0.20 & 0.2 & 0.17 & 0.25 & 0.22 & 0.25 \\
\hline $\mathrm{MgO}$ & 15.42 & 16.33 & 15.37 & 15.93 & 17.53 & 16.86 & 12.80 & 14.66 & 13.93 & 14.49 & 8.53 & 16.54 & 14.42 & 14.96 & 13.80 & 16.08 & 15.20 & 14.67 & 15.55 & 15.60 & 15.36 & 17.81 \\
\hline $\mathrm{CaO}$ & 20.14 & 19.15 & 19.29 & 19.38 & 17.70 & 21.02 & 17.43 & 14.75 & 18.94 & 11.76 & 15.95 & 20.26 & 17.50 & 14.08 & 18.29 & 19.71 & 20.04 & 20.00 & 20.95 & 19.40 & 19.80 & 17.96 \\
\hline $\mathrm{Na}_{2} \mathrm{O}$ & 0.25 & 0.26 & 0.26 & 0.26 & 0.20 & 0.25 & 0. & 0.32 & 0.31 & 0.22 & 0.25 & 0.26 & 0.29 & 0.32 & 0.41 & 0.31 & 0. & 0.30 & 0.31 & 0.25 & 0.26 & 0.18 \\
\hline $\mathrm{Cr}_{2} \mathrm{O}_{3}$ & 0.26 & 0.21 & 0.12 & 0.09 & 0.03 & 0.73 & 0.00 & 0.00 & 0.02 & 0.00 & 0.00 & 0.15 & 0.00 & 0.00 & 0.05 & 0.28 & 0.27 & 0.29 & 0.24 & 0.20 & 0.19 & 0.09 \\
\hline Total & 100.91 & 99.69 & 99.81 & 100.03 & 100.28 & 99.57 & 100.43 & 100.41 & 99.76 & 99.69 & 99.48 & 100.61 & 99.80 & 99.41 & 100.57 & 99.43 & 99.55 & 99.86 & 99.77 & 100.88 & 100.36 & 100.91 \\
\hline $\mathrm{Ca}$ & 4 & & 4 & & & & & & & & & & 36 & 29 & 38 & 41. & 41 & 42 & 43 . & 40.0 & 40.9 & 36.3 \\
\hline $\mathrm{Mg}$ & 44.1 & 47.2 & 44 & 45 & 50.4 & 48.2 & 3 & 42 & 40 & 43 & & 4 & 41 & 43. & 40 & 47 & 4 & 43 & 45 & 44.8 & 44.1 & 50.1 \\
\hline $\mathrm{Fe}$ & 14.4 & 12.9 & 14.8 & 14.2 & 13.0 & 8.6 & 25.2 & 24.5 & 19.6 & 32.0 & 39.3 & 11.8 & 21.5 & 16.5 & 20.8 & 11.4 & 14.1 & 14.1 & 10.9 & 15.2 & 15.2 & 13.6 \\
\hline
\end{tabular}

Note: For multiple analyses of a single sample, the analysis numbers (referred to in the section on least-squares modeling, but not given here) begin with 1 for the first analysis of any sample and progress to the right.

$\mathrm{I}=$ intersertal; $\mathrm{V}=$ variolitic; $\mathrm{P}=$ poikilitic; $\mathrm{p}=$ microporphyritic.

APPENDIX D

Reconnaissance Electron Microprobe Analyses (wt.\%) of Feldspars from DSDP Leg 92 Basalts

\begin{tabular}{|c|c|c|c|c|c|c|c|c|c|c|c|c|c|c|c|c|c|c|c|c|c|}
\hline & $597 \mathrm{~B}$ & $597 \mathrm{~B}$ & 597B & $597 \mathrm{~B}$ & $597 \mathrm{~B}$ & $597 \mathrm{~B}$ & $597 \mathrm{~B}$ & $597 \mathrm{~B}$ & $597 \mathrm{~B}$ & $597 \mathrm{~B}$ & $597 \mathrm{~B}$ & 597B & $597 \mathrm{~B}$ & 597B & $597 \mathrm{~B}$ & $597 \mathrm{~B}$ & $597 \mathrm{~B}$ & $597 \mathrm{~B}$ & 597B & $597 \mathrm{~B}$ & $597 \mathrm{~B}$ \\
\hline Core-Sec. & $2-1$ & $2-1$ & $2-1$ & $2-1$ & 2.1 & $2-1$ & $2-2$ & $2-2$ & $2-2$ & $2-2$ & 2.2 & 2.2 & 3-1 & 3.1 & $3-1$ & $3-2$ & $3-2$ & $3-2$ & $3-2$ & $3-2$ & $3-2$ \\
\hline Position, cm & ss & s5 & 55 & ss & s5 & 55 & 138 & 138 & 138 & 138 & 138 & 138 & 16 & 16 & 16 & 27 & 27 & 27 & 56 & 56 & 56 \\
\hline Petrology & $\mathrm{P}$ & $\mathrm{P}$ & P & P & P & $\mathrm{P}$ & P & $P$ & $\mathrm{P}$ & $\mathrm{P}$ & $\mathrm{P}$ & P & & & & & & & & & \\
\hline $\mathrm{SiO}_{2}$ & 47.99 & 47.64 & 47.99 & 51.33 & 51.20 & 50.50 & 47.88 & 48.03 & 46.67 & 51.68 & 51.53 & 52.40 & 53.40 & 52.86 & 51.17 & 54.61 & 54.54 & 54.39 & 52.47 & 52.37 & 51.81 \\
\hline $\mathrm{Al}_{2} \mathrm{O}_{3}$ & 33.24 & 32.79 & 32.77 & 29.24 & 29.75 & 30.37 & 33.36 & 33.28 & 33.95 & 29.29 & 29.74 & 29.71 & 28.86 & 28.94 & 30.25 & 27.74 & 27.79 & 28.35 & 29.64 & 29.51 & 30.09 \\
\hline $\mathrm{FeO}$ & 0.52 & 0.52 & 0.56 & 0.86 & 0.80 & 0.69 & 0.55 & 0.49 & 0.37 & 0.83 & 0.82 & 0.77 & 0.76 & 0.83 & 0.65 & 0.87 & 0.93 & 0.91 & 0.63 & 0.60 & 0.55 \\
\hline & 17.49 & 17.0 & 17.00 & 14.68 & 14.43 & 14. & 17 & 17 & 18. & 13 & 14 & 13. & 13.08 & 13.00 & 14. & 11.75 & 11. & 12.18 & 13.67 & 13.66 & 14.04 \\
\hline $\mathrm{Na}_{2} \mathrm{O}$ & 1.73 & 1.9 & 1.93 & 3.25 & 3.28 & 2.99 & 1.78 & 1.79 & 1.34 & 3. & 3. & 3.76 & 4.05 & 4.15 & 3. & 5. & 4. & 4.73 & 3. & 3.80 & 3.73 \\
\hline $\mathrm{K}_{2} \mathrm{C}$ & 0.01 & 0.02 & 0.01 & 0.01 & 0.02 & 0.03 & 0.01 & 0.01 & 0.00 & 0.03 & 0.01 & 0.02 & 0.02 & 0.02 & 0.01 & 0.05 & 0.05 & 0.04 & 0.01 & 0.02 & 0.02 \\
\hline Total & 100.98 & 99.98 & 100.26 & 99.37 & 99.48 & 99.47 & 100.97 & 100.97 & 100.40 & 99.30 & 99.68 & 100.45 & 100.17 & 99.80 & 99.85 & 100.15 & 100.04 & 100.60 & 100.26 & 99.96 & 100.24 \\
\hline An & 84.7 & 82.9 & 82.9 & 71.4 & 70.8 & 73.2 & 84.3 & 84.2 & 88.2 & 68.1 & 69.2 & 66.9 & 64.0 & 63.3 & 70.1 & 55.7 & 56.4 & 58.6 & 66.3 & 66.5 & 67.4 \\
\hline
\end{tabular}

Note: For multiple analyses of a single sample, the analysis numbers (referred to in the soction on least-squares modeling, but not given here) begin with 1 for the first analysis of any sample and progress to the right. 
Appendix B (continued).

\begin{tabular}{|c|c|c|c|c|c|c|c|c|c|c|c|c|c|c|c|c|c|c|c|c|c|}
\hline $597 \mathrm{C}$ & $597 \mathrm{C}$ & $597 \mathrm{C}$ & $597 \mathrm{C}$ & $597 \mathrm{C}$ & $597 \mathrm{C}$ & $597 \mathrm{C}$ & $597 \mathrm{C}$ & $597 \mathrm{C}$ & $597 \mathrm{C}$ & $597 \mathrm{C}$ & $597 \mathrm{C}$ & $597 \mathrm{C}$ & $597 \mathrm{C}$ & $597 \mathrm{C}$ & $597 \mathrm{C}$ & $597 \mathrm{C}$ & $597 \mathrm{C}$ & $597 \mathrm{C}$ & $597 \mathrm{C}$ & $597 \mathrm{C}$ & $597 \mathrm{C}$ \\
\hline $3-3$ & $4-1$ & $4-1$ & 4.2 & $4-3$ & $4-3$ & $4-3$ & 4.4 & 4.4 & $4-5$ & 4.5 & $4-6$ & 4.6 & 4.6 & 5.1 & 5.1 & 5.2 & 5.2 & 5.2 & $6-1$ & $6-1$ & $6-2$ \\
\hline 58 & 92 & 126 & 29 & 36 & 74 & 107 & 11 & 127 & 76 & 120 & 8 & 49 & 65 & 32 & 133 & 12 & 24 & 55 & 69 & 128 & 44 \\
\hline 49.95 & 48.74 & 50.25 & 49.70 & 50.24 & 50.15 & 49.37 & 50.23 & 50.14 & 50.13 & 49.71 & 50.23 & 50.51 & 49.77 & 49.83 & 49.61 & 49.03 & 50.37 & 49.82 & 49.74 & 49.95 & 48.87 \\
\hline 1.35 & 1.32 & 1.34 & 1.33 & 1.34 & 1.35 & 1.32 & 1.35 & 1.36 & 1.31 & 1.32 & 1.33 & 1.33 & 1.40 & 1.28 & 1.32 & 1.21 & 1.21 & 1.21 & 1.20 & 1.19 & 1.16 \\
\hline 14.97 & 13.44 & 14.76 & 14.78 & 14.93 & 14.59 & 14.47 & 14.88 & 14.81 & 14.71 & 14.62 & 14.91 & 15.51 & 13.87 & 15.06 & 14.90 & 14.33 & 15.50 & 14.72 & 15.34 & 15.30 & 15.23 \\
\hline 10.74 & 12.02 & 11.41 & 11.13 & 11.47 & 11.79 & 11.40 & 11.75 & 11.23 & 11.83 & 11.62 & 11.31 & 11.32 & 11,73 & 11.76 & 11.40 & 12.68 & 11.25 & 11.20 & 11.48 & 10.98 & 11.75 \\
\hline 0.16 & 0.17 & 0.16 & 0.15 & 0.16 & 0.16 & 0.15 & 0.16 & 0.16 & 0.17 & 0.16 & 0.15 & 0.15 & 0.18 & 0.16 & 0.16 & 0.17 & 0.16 & 0.15 & 0.17 & 0.16 & 0.16 \\
\hline 7.09 & 7.12 & 7.26 & 7,27 & 7.20 & 7.46 & 7.00 & 7.28 & 7.49 & 7.01 & 7.36 & 7.38 & 7.29 & 7.59 & 6.95 & 6.93 & 6.64 & 7.94 & 6.75 & 6.41 & 6.69 & 6.38 \\
\hline 12.22 & 12.73 & 11.80 & 11.69 & 11.90 & 11.66 & 11,54 & 11.82 & 11.73 & 12.07 & 11,77 & 11.89 & 12.18 & 11.16 & 11.63 & 12.12 & 11.88 & 12.11 & 11.83 & 12.76 & 12.41 & 12.37 \\
\hline 2.38 & 2.03 & 2.56 & 2.56 & 2.81 & 2.74 & 2.60 & 2.28 & 2.51 & 2.02 & 2.34 & 2.43 & 2.29 & 2.45 & 1.94 & 2.37 & 2.69 & 2.50 & 2.06 & 2.26 & 2.19 & 2.34 \\
\hline 0.36 & 0.61 & 0.10 & 0.08 & 0.10 & 0.10 & 0.10 & 0.08 & 0.12 & 0.09 & 0.09 & 0.09 & 0.09 & 0.15 & 0.46 & 0.64 & 0.96 & 0.09 & 0.70 & 0.44 & 0.45 & 0.56 \\
\hline 0.12 & 0.12 & 0.11 & 0.16 & 0.09 & 0.09 & 0.10 & 0.11 & 0.16 & 0.13 & 0.12 & 0.14 & 0.10 & 0.09 & 0.15 & 0.14 & 0.09 & 0.14 & 0.11 & 0.10 & 0.11 & 0.07 \\
\hline 0.46 & 2.36 & 0.19 & 0.37 & 0.19 & 0.09 & 0.15 & 0.21 & 0.15 & 0.22 & 0.41 & 0.27 & 0.12 & 0.21 & 0.87 & 0.82 & 0.71 & 0.53 & 0.73 & 0.58 & 0.65 & 0.39 \\
\hline 99.80 & 100.66 & 99.94 & 99.22 & 100.43 & 100.18 & 98.20 & 100.15 & 99.86 & 99.69 & 99.52 & 100.13 & 100.89 & 98.60 & 100.09 & 100.41 & 100.39 & 101,80 & 99.28 & 100.48 & 100.08 & 99.28 \\
\hline 87 & 86 & 84 & 83 & 86 & 83 & 82 & 83 & 84 & 78 & 80 & 83 & 78 & 82 & 79 & 83 & 76 & 70 & 78 & 75 & 72 & 72 \\
\hline 33 & 31 & 30 & 31 & 33 & 32 & 32 & 32 & 34 & 31 & 32 & 31 & 30 & 32 & 30 & 32 & 29 & 29 & 32 & 29 & 30 & 29 \\
\hline 4.4 & 5.0 & 4.6 & 4.5 & 5.0 & 4.6 & 4.2 & 4.4 & 4.0 & 3.9 & 5.1 & 5.1 & 4.7 & 4.4 & 4.8 & 4.7 & 4.5 & 3.1 & 4.0 & 4.2 & 4.6 & 4.4 \\
\hline 13.5 & 16.1 & 3.3 & 2.3 & 3.7 & 2.9 & 2.7 & 3.2 & 3.6 & 3.7 & 3.6 & 3.3 & 3.2 & 4.0 & 16.9 & 17.0 & 23.9 & 2.3 & 18.5 & 21.9 & 12.5 & 13.1 \\
\hline 104 & 94 & 91 & 93 & 85 & 89 & 91 & 90 & 92 & 85 & 86 & 92 & 88 & 84 & 97 & 108 & 90 & 82 & 106 & 91 & 93 & 91 \\
\hline 239 & 203 & 196 & 216 & 223 & 213 & 205 & 201 & 213 & 219 & 211 & 200 & 215 & 213 & 225 & 219 & 256 & 283 & 230 & 298 & 279 & 287 \\
\hline 89 & 60 & 75 & 72 & 75 & 72 & 67 & 70 & 102 & 77 & 77 & 72 & 79 & 76 & 71 & 85 & 69 & 89 & 66 & 74 & 68 & 66 \\
\hline 356 & 344 & 352 & 357 & 356 & 353 & 358 & 329 & 365 & 349 & 353 & 383 & 344 & 390 & 335 & 345 & 330 & 330 & 337 & 297 & 280 & 331 \\
\hline 161 & 165 & 136 & 124 & 126 & 129 & 124 & 119 & 128 & 111 & 121 & 138 & 123 & 142 & 136 & 133 & 106 & 115 & 133 & 123 & 125 & 120 \\
\hline 94 & 86 & 84 & 80 & 97 & 84 & 85 & 84 & 84 & 81 & 88 & 91 & 83 & 83 & 97 & 83 & 73 & 75 & 84 & 79 & 85 & 74 \\
\hline 0.00 & 0.00 & 0.00 & 0.00 & 0.00 & 0.00 & 0. & 0. & 0. & 2. & 0. & 0 & 0.48 & 0,16 & 1.44 & 0.00 & 0.00 & 0.00 & 0.60 & 0.00 & 0.13 & 0.00 \\
\hline 2.13 & 3.60 & 0.59 & 0.47 & 0.59 & 0.59 & 0.59 & 0.47 & 0.71 & 0.53 & 0.53 & 0.53 & 0.53 & 0.89 & 2.72 & 3.78 & 5.67 & 0.53 & 4.14 & 2.60 & 2.66 & 3.31 \\
\hline 20.14 & 17.18 & 21.66 & 21.66 & 23.78 & 23.18 & 22.00 & 19.29 & 21.24 & 17.09 & 19.80 & 20.56 & 19.38 & 20.73 & 16.42 & 20.05 & 22.61 & 21.15 & 17.43 & 19.12 & 18.53 & 19.80 \\
\hline 29.11 & 25.77 & 28.50 & 28.61 & 27.84 & 27.22 & 27.52 & 30.14 & 28.80 & 30.81 & 29.13 & 29.52 & 31.78 & 26.41 & 31.03 & 28.14 & 24.20 & 30.81 & 28.86 & 30.42 & 30.60 & 29.41 \\
\hline 0.00 & 0.00 & 0.00 & 0.00 & 0.00 & 0.00 & 0.00 & 0.00 & 0.00 & 0.00 & 0.00 & 0.00 & 0.00 & 0.00 & 0.00 & 0.00 & 0.08 & 0.00 & 0.00 & 0.00 & 0.00 & 0.00 \\
\hline 25.10 & 30.02 & 23.99 & 23.16 & 25.05 & 24.57 & 23.81 & 22.74 & 23.15 & 23.14 & 23.30 & 23.33 & 22.88 & 23.19 & 21.06 & 25.46 & 28.14 & 23.12 & 23.86 & 26.49 & 24.79 & 25.92 \\
\hline 15.61 & 12.01 & 18.04 & 17.53 & 12.23 & 14.03 & 16.53 & 20.10 & 18.64 & 19.40 & 19.92 & 19.53 & 19.53 & 20.60 & 20.21 & 11.50 & 0.00 & 15.41 & 17.72 & 13.42 & 16.89 & 8.99 \\
\hline 1.17 & 3.30 & 0.72 & 1.16 & 4.53 & 4.15 & 1.41 & 0.00 & 0.82 & 0.00 & 0.00 & 0.00 & 0.00 & 0.00 & 0.00 & 4.38 & 12.64 & 4.21 & 0.00 & 1.87 & 0.00 & 5.55 \\
\hline 2.34 & 2.61 & 2.48 & 2.42 & 2.49 & 2.56 & 2.48 & 2.56 & 2.44 & 2.57 & 2.53 & 2.46 & 2.46 & 2.55 & 2.56 & 2.48 & 2.76 & 2.45 & 2.44 & 2.50 & 2.39 & 2.56 \\
\hline 2.56 & 2.51 & 2.54 & 2.53 & 2.54 & 2.56 & 2.51 & 2.56 & 2.58 & 2.49 & 2.51 & 2.53 & 2.53 & 2.66 & 2.43 & 2.51 & 2.30 & 2.30 & 2.30 & 2.28 & 2.26 & 2.20 \\
\hline 0.28 & 0.28 & 0.25 & 0.37 & 0.21 & 0.21 & 0.23 & 0.25 & 0.37 & 0.30 & 0.28 & 0.32 & 0.23 & 0.21 & 0.35 & 0.32 & 0.21 & 0.32 & 0.25 & 0.23 & 0.25 & 0.16 \\
\hline
\end{tabular}

Appendix C (continued).

\begin{tabular}{|c|c|c|c|c|c|c|c|c|c|c|c|c|c|c|c|c|c|c|c|c|c|c|}
\hline $597 \mathrm{C}$ & $597 \mathrm{C}$ & $597 \mathrm{C}$ & $597 \mathrm{C}$ & $597 \mathrm{C}$ & $597 \mathrm{C}$ & $597 \mathrm{C}$ & $597 \mathrm{C}$ & $597 \mathrm{C}$ & $597 \mathrm{C}$ & $597 \mathrm{C}$ & $597 \mathrm{C}$ & $597 \mathrm{C}$ & $597 \mathrm{C}$ & $597 \mathrm{C}$ & $597 \mathrm{C}$ & $597 \mathrm{C}$ & $597 \mathrm{C}$ & $597 \mathrm{C}$ & $597 \mathrm{C}$ & $597 \mathrm{C}$ & $597 \mathrm{C}$ & $597 \mathrm{C}$ \\
\hline $3-2$ & $3-2$ & $4-2$ & $4-2$ & $4-2$ & 5.2 & $5-2$ & 5.2 & $5-2$ & 5.2 & $6-3$ & $6-3$ & $6-3$ & 7.1 & 7.1 & 7.1 & 7.2 & 7.2 & 7.2 & $7-3$ & 7.3 & 7.3 & $7-3$ \\
\hline 117 & 117 & 29 & 29 & 29 & 12 & 12 & 12 & 12 & 12 & 69 & 69 & 69 & 53 & 53 & 53 & 136 & 136 & 136 & 122 & 122 & 122 & 122 \\
\hline P & P & v & v & $\mathrm{v}$ & I & I & I & I & P & v & $\mathrm{v}$ & $\mathrm{v}$ & $\mathrm{P}$ & $\mathbf{P}$ & $P$ & $\mathrm{P}$ & $\mathrm{P}$ & $\mathrm{P}$ & $\mathrm{v}$ & $\mathrm{v}$ & $\mathrm{v}$ & 1 \\
\hline 51.73 & 51.10 & 51.63 & 50.74 & 51.04 & 51.43 & 50.84 & 51.66 & 52.82 & 51.55 & 50.11 & 50.89 & 51.07 & 51.59 & 51.53 & 50.92 & 50.18 & 51.24 & 50.93 & 51.71 & 51.68 & 51.96 & 52.03 \\
\hline 0.82 & 0.82 & 0.95 & 0.90 & 0.92 & 0.73 & 0.95 & 0.80 & 0.55 & 0.66 & 0.90 & 0.86 & 0.89 & 0.68 & 0.79 & 0.73 & 1.03 & 0.84 & 0.82 & 0.75 & 0.90 & 0.78 & 0.75 \\
\hline 3.59 & 3.00 & 3.08 & 2.55 & 3.62 & 2.41 & 2.10 & 2.50 & 2.00 & 3.69 & 4.02 & 3.41 & 3.16 & 2.17 & 2.76 & 3.14 & 2.84 & 3.50 & 3.14 & 3.64 & 3.63 & 2.99 & 3.79 \\
\hline 9.11 & 10.18 & 9.15 & 14.66 & 8.86 & 11.14 & 15.67 & 11.59 & 12.19 & 7.14 & 9.15 & 9.40 & 10.07 & 12.59 & 7.48 & 9.51 & 14.48 & 8.42 & 10.20 & 7.30 & 7.96 & 9.81 & 7.55 \\
\hline 0.25 & 0.25 & 0.23 & 0.36 & 0.22 & 0.28 & 0.40 & 0.31 & 0.33 & 0.20 & 0.23 & 0.28 & 0.27 & 0.36 & 0.20 & 0.2 & 0.34 & 0. & 0.27 & 0. & 0.20 & 0.28 & 0.19 \\
\hline 16.48 & 16.36 & 15.70 & 15.25 & 15.50 & 15.21 & 13.80 & 15,40 & 17.32 & 17.12 & 15.28 & 15.99 & 15.31 & 17.00 & 16.20 & 16.27 & 13.29 & 15.86 & 15.23 & 15.91 & 15.93 & 17.07 & 16.20 \\
\hline 18.35 & 17.60 & 19.41 & 14.85 & 19.36 & 18.54 & 16.22 & 17.96 & 15.23 & 18.77 & 18.79 & 18.31 & 18.77 & 14.89 & 20.31 & 17.97 & 17.92 & 19.54 & 19.16 & 10.53 & 20.23 & 17.05 & 19.95 \\
\hline 0.23 & 0.23 & 0.23 & 0.26 & 0.25 & 0.24 & 0.26 & 0.29 & 0.29 & 0.24 & 0.26 & 0.23 & 0.25 & 0.19 & 0.26 & 0.2 & 0.33 & 0. & 0.30 & 0.24 & 0. & 0.23 & 0.21 \\
\hline 0.12 & 0.09 & 0.03 & 0.02 & 0.10 & 0.02 & 0.00 & 0.02 & 0.03 & 0.34 & 0.21 & 0.12 & 0.15 & 0.07 & 0.07 & 0.00 & 0.00 & 0.21 & 0.03 & 0.29 & 0.14 & 0.14 & 0.28 \\
\hline 100.68 & 99.63 & 100.41 & 99.59 & 99.87 & 100.00 & 100.24 & 100.53 & 100.76 & 99.71 & 98.95 & 99.49 & 99.94 & 99.54 & 99.60 & 99.02 & 100.41 & 100.09 & 100.08 & 90.56 & 100.90 & 100.31 & 100.95 \\
\hline 37.9 & 36 & 4 & 31 & 4 & 38 & 3. & 3 & 3 & $3 \mathrm{~s}$ & 39 & 38 & 39. & 30. & 41 & 37. & 37. & 40 & 39. & 42. & 41. & 35. & 41.2 \\
\hline 47.4 & 47.1 & 45.1 & 44.7 & 45.1 & 43 & 40.3 & 44.2 & 49.3 & 49.5 & 45.0 & 46 & 44 & 48 & 46 & 47 & 38 & 45 & 43 & 45 & 45 & 49.0 & 16.5 \\
\hline 14.7 & 16.5 & 14.8 & 24.1 & 14.5 & 18.0 & 25.7 & 18.7 & 19.5 & 11.6 & 15.1 & 15.3 & 16.4 & 20.3 & 12.0 & 15.5 & 23.7 & 13.6 & 16.5 & 11.8 & 12.8 & 15.8 & 12.2 \\
\hline
\end{tabular}

Appendix D (continued).

\begin{tabular}{|c|c|c|c|c|c|c|c|c|c|c|c|c|c|c|c|c|c|c|c|c|c|c|}
\hline $\begin{array}{c}397 \mathrm{C} \\
3.2 \\
20\end{array}$ & $\begin{array}{c}597 \mathrm{C} \\
3-2 \\
20\end{array}$ & $\begin{array}{c}597 \mathrm{C} \\
3-2 \\
20\end{array}$ & $\begin{array}{c}597 \mathrm{C} \\
3-2 \\
117\end{array}$ & $\begin{array}{c}597 c \\
3-2 \\
117\end{array}$ & $\begin{array}{c}597 \mathrm{C} \\
3.2 \\
117\end{array}$ & $\begin{array}{c}597 \mathrm{C} \\
4-2 \\
29 \\
\mathrm{P}\end{array}$ & $\begin{array}{c}597 \mathrm{C} \\
4-2 \\
29 \\
\mathrm{P}\end{array}$ & $\begin{array}{c}597 C \\
4-2 \\
29\end{array}$ & $\begin{array}{c}597 \mathrm{C} \\
4-2 \\
29\end{array}$ & $\begin{array}{c}597 \mathrm{C} \\
5-2 \\
12\end{array}$ & $\begin{array}{c}597 \mathrm{C} \\
5-2 \\
12\end{array}$ & $\begin{array}{c}597 c \\
5-2 \\
12\end{array}$ & $\begin{array}{c}597 \mathrm{C} \\
6-3 \\
69 \\
\mathrm{P}\end{array}$ & $\begin{array}{c}597 \mathrm{C} \\
6-3 \\
69 \\
\mathrm{P}\end{array}$ & $\begin{array}{c}597 \mathrm{C} \\
6-3 \\
69 \\
\mathrm{P}\end{array}$ & $\begin{array}{c}597 \mathrm{C} \\
6-3 \\
69\end{array}$ & $\begin{array}{c}597 C \\
6-3 \\
69\end{array}$ & $\begin{array}{c}597 C \\
6-3 \\
69\end{array}$ & $\begin{array}{c}597 \mathrm{C} \\
7-1 \\
53\end{array}$ & $\begin{array}{c}597 \mathrm{C} \\
7.1 \\
53\end{array}$ & $\begin{array}{c}597 \mathrm{C} \\
7-1 \\
53\end{array}$ & $\begin{array}{c}597 \mathrm{C} \\
7.2 \\
136\end{array}$ \\
\hline & & & & & & & & & & & & & & & & & & & & & & 9s \\
\hline & & & & & & & & & & & & & & & & & & & & & & $\begin{array}{l}.95 \\
.56\end{array}$ \\
\hline .54 & 11 & & & & & & & & & & & & & & & & & & & & & 4.97 \\
\hline 0.03 & 0.06 & & & & & & & & & & & & & & & & & & 1 & & 001 & 0.0 \\
\hline & 99.3 & 00.02 & 0.77 & 100.51 & 100.98 & 100.11 & 100.57 & 99.97 & 99.84 & 100.01 & 99.99 & 100.42 & 99.86 & 100.12 & 100.00 & 99.26 & 99.69 & 97.53 & 99.85 & 99.97 & 100.96 & 100.4 \\
\hline & 56.9 & 63.5 & 69 & 80.8 & 73.4 & 86.1 & 90.8 & 7.8 & 73.8 & 69 & 7.6 & 60. & 8.8 & 88.6 & 70 & 69.0 & 68. & 56.9 & 70.5 & 74.0 & 70.2 & 72.9 \\
\hline
\end{tabular}


Appendix B (continued).

\begin{tabular}{|c|c|c|c|c|c|c|c|c|c|c|c|c|c|c|c|c|c|c|c|c|}
\hline $\begin{array}{l}\text { Hole } \\
\text { Core-Sec. } \\
\text { Position, } \mathrm{cm}\end{array}$ & $\begin{array}{l}597 \mathrm{C} \\
6-3 \\
67\end{array}$ & $\begin{array}{l}597 \mathrm{C} \\
6-3 \\
69\end{array}$ & $\begin{array}{c}597 C \\
6-4 \\
126\end{array}$ & $\begin{array}{l}597 \mathrm{C} \\
6-5 \\
96\end{array}$ & $\begin{array}{c}597 \mathrm{C} \\
7-1 \\
23\end{array}$ & $\begin{array}{l}597 \mathrm{C} \\
7-1 \\
53\end{array}$ & $\begin{array}{l}597 \mathrm{C} \\
7-1 \\
112\end{array}$ & $\begin{array}{l}597 \mathrm{C} \\
7.2 \\
27\end{array}$ & $\begin{array}{l}597 \mathrm{C} \\
7-2 \\
61\end{array}$ & $\begin{array}{c}597 \mathrm{C} \\
7-2 \\
136\end{array}$ & $\begin{array}{c}597 \mathrm{C} \\
7-3 \\
43\end{array}$ & $\begin{array}{c}597 \mathrm{C} \\
7-3 \\
122\end{array}$ & $\begin{array}{c}597 \mathrm{C} \\
7.4 \\
8\end{array}$ & $\begin{array}{c}597 \mathrm{C} \\
7.4 \\
88\end{array}$ & $\begin{array}{l}597 \mathrm{C} \\
7-4 \\
101\end{array}$ & $\begin{array}{c}597 \mathrm{C} \\
7-4 \\
114\end{array}$ & $\begin{array}{l}597 \mathrm{C} \\
7.5 \\
16\end{array}$ & $\begin{array}{l}597 \mathrm{C} \\
7.5 \\
67\end{array}$ & $\begin{array}{l}597 \mathrm{C} \\
7.5 \\
90\end{array}$ & $\begin{array}{c}597 \mathrm{C} \\
8-1 \\
6\end{array}$ \\
\hline $\mathrm{SiO}_{2}$ & 50.15 & 50.24 & 49.97 & 47.60 & 49.67 & 49.45 & 49.79 & 50.08 & 49.79 & 49.89 & 49.13 & 49.81 & 49.43 & 49.51 & 49.72 & 50.29 & 50.44 & 50.13 & 49.96 & 50.47 \\
\hline $\mathrm{TiO}_{2}$ & 1.22 & 1.19 & 1.44 & 1.15 & 1.19 & 1.11 & 1.15 & 1.20 & 1.18 & 1.19 & 1.19 & 1.17 & 1.17 & 1.17 & 1.28 & 1.18 & 1.36 & 1.20 & 1.20 & 1.35 \\
\hline $\mathrm{Al}_{2} \mathrm{O}_{3}$ & 15.09 & 15.50 & 13.82 & 13.36 & 13.87 & 15.06 & 15.08 & 15.25 & 15.40 & 15.96 & 14.97 & 14.95 & 15.06 & 15.41 & 14.10 & 15.77 & 14.23 & 15.55 & 15.19 & 15.44 \\
\hline $\mathrm{Fe}_{2} \mathrm{O}_{3}$ & 10.88 & 11.10 & 11.55 & 12.24 & 12.61 & 11.54 & 11.63 & 10.76 & 10.41 & 9.63 & 11.83 & 11.74 & 11.17 & 10.53 & 12.47 & 10.60 & 11.92 & 10.96 & 11.14 & 10.65 \\
\hline Mno & 0.16 & 0.16 & 0.17 & 0.18 & 0.17 & 0.20 & 0.15 & 0.17 & 0.16 & 0.15 & 0.17 & 0.17 & 0.16 & 0.17 & 0.19 & 0.17 & 0.18 & 0.16 & 0.17 & 0.16 \\
\hline $\mathrm{MgO}$ & 7.93 & 7.85 & 7.59 & 7.16 & 7.38 & 6.78 & 7.35 & 7.85 & 7.57 & 7.13 & 6.39 & 6.87 & 7.02 & 7.59 & 7.56 & 7.52 & 7.95 & 7.56 & 7.62 & 7.16 \\
\hline $\mathrm{CaO}$ & 12.06 & 12.16 & 11.76 & 13.85 & 12.19 & 12.72 & 12.23 & 12.43 & 12.44 & 12.66 & 12.25 & 12.19 & 12.40 & 12.48 & 12.10 & 12.68 & 12.04 & 12.46 & 12.20 & 12.30 \\
\hline $\mathrm{Na}_{2} \mathrm{O}$ & 2.57 & 2.31 & 2.52 & 1.64 & 2.62 & 2.13 & 2.17 & 2.33 & 1.82 & 2.33 & 1.93 & 2.04 & 1.63 & 2.24 & 2.18 & 2.52 & 2.52 & 2.34 & 2.22 & 2.68 \\
\hline $\mathrm{K}_{2} \mathrm{O}$ & 0.08 & 0.08 & 0.11 & 0.65 & 0.86 & 0.69 & 0.09 & 0.07 & 0.08 & 0.08 & 0.65 & 0.54 & 0.35 & 0.07 & 0.72 & 0.05 & 0.05 & 0.05 & 0.07 & 0.09 \\
\hline $\mathrm{P}_{2} \mathrm{O}_{5}$ & 0.17 & 0.10 & 0.12 & 0.10 & 0.14 & 0.10 & 0.13 & 0.09 & 0.08 & 0.11 & 0.15 & 0.13 & 0.13 & 0.09 & 0.12 & 0.12 & 0.13 & 0.12 & 0.15 & 0.16 \\
\hline Lol & 0.34 & 0.43 & 0.13 & 2.38 & 0.48 & 0.98 & 0.23 & 0.21 & 0.31 & 0.30 & 0.35 & 0.58 & 0.54 & 0.23 & 0.41 & 0.32 & 0.00 & 0.32 & 0.40 & 0.46 \\
\hline Total & 100.65 & 101.12 & 99.18 & 100.31 & 101.18 & 100.76 & 100.00 & 100.44 & 99.24 & 99.43 & 99.01 & 100.19 & 99.06 & 99.49 & 100.85 & 101.22 & 100.82 & 100.85 & 100.32 & 100.92 \\
\hline $\mathrm{Zr}$ & 74 & 71 & 87 & 74 & 74 & 72 & 74 & 71 & 72 & 74 & 76 & 74 & 73 & 73 & 79 & 72 & 82 & 73 & 72 & 82 \\
\hline $\mathrm{Y}$ & 29 & 28 & 33 & 29 & 30 & 28 & 27 & 28 & 28 & 27 & 29 & 29 & 28 & 28 & 32 & 28 & 31 & 29 & 28 & 31 \\
\hline $\mathrm{Nb}$ & 4.2 & 4.4 & 4.4 & 4.8 & 4.2 & 4.3 & 4.3 & 4.2 & 4.6 & 4.6 & 4.3 & 4.8 & 4.3 & 3.7 & 3.7 & 4.3 & 4.2 & 3.6 & 3.8 & 4.5 \\
\hline $\mathrm{Rb}$ & 1.6 & 3.0 & 2.6 & 17.3 & 21.7 & 17.4 & 2.6 & 1.7 & 2.6 & 1.7 & 16.1 & 12.8 & 7.8 & 2.2 & 18.8 & 2.7 & 2.2 & 2.5 & 3.2 & 3.0 \\
\hline Sr & 83 & 83 & 86 & 86 & 80 & 90 & 84 & 84 & 85 & 88 & 87 & 87 & 83 & 84 & 84 & 88 & 83 & 84 & 93 & 93 \\
\hline $\mathrm{Cr}$ & 310 & 313 & 216 & 296 & 353 & 314 & 324 & 313 & 292 & 306 & 316 & 291 & 288 & 292 & 298 & 313 & 287 & 286 & 266 & 205 \\
\hline $\mathrm{Ni}$ & 91 & 91 & 95 & 102 & 67 & 95 & 88 & 99 & 101 & 109 & 68 & 70 & 92 & 78 & 77 & 108 & 68 & 89 & 101 & 127 \\
\hline$v$ & 308 & 298 & 394 & 342 & 349 & 356 & 306 & 347 & 317 & 341 & 307 & 359 & 323 & 313 & 366 & 304 & 353 & 317 & 298 & 319 \\
\hline $\mathrm{Cu}$ & 116 & 116 & 140 & 94 & 111 & 78 & 131 & 123 & 129 & 119 & 76 & 75 & 103 & 115 & 102 & 124 & 127 & 118 & 102 & 131 \\
\hline $\mathrm{Zn}$ & 79 & 78 & 102 & 76 & 78 & 76 & 80 & 78 & 78 & 81 & 75 & 78 & 75 & 72 & 81 & 73 & 86 & 77 & 67 & 85 \\
\hline Q & 0.00 & 0.00 & 0.00 & 0.00 & 0.00 & 0.00 & 0.18 & 0.00 & 1.82 & 0.05 & 0.29 & 0.16 & 2.20 & 0.00 & 0.00 & 0.00 & 0.00 & 0.00 & 0.07 & 0.00 \\
\hline Or & 0.47 & 0.47 & 0.65 & 3.84 & 5.08 & 4.08 & 0.53 & 0.41 & 0.47 & 0.47 & 3.84 & 3.19 & 2.07 & 0.41 & 4.25 & 0.30 & 0.30 & 0.30 & 0.41 & 0.53 \\
\hline $\mathrm{Ab}$ & 21.75 & 19.55 & 21.32 & 13.88 & 22.17 & 18.02 & 18.36 & 19.72 & 15,40 & 19.72 & 16.33 & 17.26 & 13.79 & 18.95 & 18.45 & 21. 32 & 21.32 & 19.80 & 18.78 & 22.68 \\
\hline An & 29.41 & 31.70 & 26.08 & 27.18 & 23.55 & 29.50 & 31.15 & 30.95 & 33.62 & 32.86 & 30.27 & 30.05 & 32.75 & 31.79 & 26.57 & 31.58 & 27.38 & 31.79 & 31.28 & 29.84 \\
\hline $\mathrm{Ne}$ & 0.00 & 0.00 & 0.00 & 0.00 & 0.00 & 0.00 & 0.00 & 0.00 & 0.00 & 0.00 & 0.00 & 0.00 & 0.00 & 0.00 & 0.00 & 0.00 & 0.00 & 0.00 & 0.00 & 0.00 \\
\hline Di & 23.88 & 22.82 & 25.71 & 33.56 & 29.56 & 27.05 & 23.48 & 23.54 & 22.46 & 23.79 & 24.29 & 24.28 & 22.86 & 24.07 & 26.79 & 24.91 & 25.74 & 23.87 & 23.07 & 24.59 \\
\hline $\mathrm{Hy}$ & 14.73 & 18.56 & 18.02 & 7.63 & 1.86 & 10.90 & 20.07 & 16.63 & 19.58 & 16.81 & 17.44 & 18.60 & 18.95 & 16.76 & 12.49 & 13.20 & 16.99 & 17.26 & 20.30 & 14.33 \\
\hline ol & 4.07 & 1.74 & 0.76 & 5.73 & 12.07 & 4.40 & 0.00 & 2.23 & 0.00 & 0.00 & 0.00 & 0.00 & 0.00 & 1.65 & 5.41 & 3.87 & 2.61 & 1.64 & 0.00 & 2.32 \\
\hline Mt & 2.37 & 2.41 & 2.51 & 2.66 & 2.74 & 2.51 & 2.53 & 2.34 & 2.26 & 2.09 & 2.57 & 2.55 & 2.43 & 2.29 & 2.71 & 2.31 & 2.59 & 2.38 & 2.42 & 2.32 \\
\hline II & 2.32 & 2.26 & 2.73 & 2.18 & 2.26 & 2.11 & 2.18 & 2.28 & 2.24 & 2.26 & 2.26 & 2.22 & 2.22 & 2.22 & 2.43 & 2.24 & 2.58 & 2.28 & 2.28 & 2.56 \\
\hline Ap & 0.39 & 0.23 & 0.28 & 0.23 & 0.32 & 0.23 & 0.30 & 0.21 & 0.19 & 0.25 & 0.35 & 0.30 & 0.30 & 0.21 & 0.28 & 0.28 & 0.30 & 0.28 & 0.35 & 0.37 \\
\hline
\end{tabular}

Appendix C (continued).

\begin{tabular}{|c|c|c|c|c|c|c|c|c|c|c|c|c|c|c|c|c|c|c|c|c|c|}
\hline $\begin{array}{l}\text { Hole } \\
\text { Core-Sec. } \\
\text { Position, cm } \\
\text { Petrology } y^{\mathrm{a}}\end{array}$ & $\begin{array}{c}597 \mathrm{C} \\
7.3 \\
122 \\
1\end{array}$ & $\begin{array}{c}597 \mathrm{C} \\
7-3 \\
122 \\
1\end{array}$ & $\begin{array}{c}597 \mathrm{C} \\
7-5 \\
90 \\
\mathrm{P}\end{array}$ & $\begin{array}{c}597 \mathrm{C} \\
7.5 \\
90 \\
\mathrm{P}\end{array}$ & $\begin{array}{c}597 \mathrm{C} \\
7.5 \\
90 \\
\mathrm{P}\end{array}$ & $\begin{array}{c}597 \mathrm{C} \\
8-4 \\
23 \\
\mathrm{P}\end{array}$ & $\begin{array}{c}597 \mathrm{C} \\
8-4 \\
23 \\
P\end{array}$ & $\begin{array}{c}597 \mathrm{C} \\
8-4 \\
23 \\
\mathrm{P}\end{array}$ & $\begin{array}{c}597 \mathrm{C} \\
8-5 \\
49 \\
P\end{array}$ & $\begin{array}{c}597 \mathrm{C} \\
8-5 \\
49 \\
P\end{array}$ & $\begin{array}{c}597 \mathrm{C} \\
8-5 \\
49 \\
\mathrm{P}\end{array}$ & $\begin{array}{c}597 C \\
8-6 \\
56 \\
P\end{array}$ & $\begin{array}{c}597 \mathrm{C} \\
8-6 \\
56 \\
P\end{array}$ & $\begin{array}{c}597 \mathrm{C} \\
8-6 \\
56 \\
\mathrm{P}\end{array}$ & $\begin{array}{l}397 C \\
9-1 \\
94 \\
\mathrm{I}\end{array}$ & $\begin{array}{l}597 \mathrm{C} \\
9-1 \\
94 \\
\mathrm{I}\end{array}$ & $\begin{array}{c}597 C \\
9-1 \\
94 \\
1\end{array}$ & $\begin{array}{l}597 C \\
9-1 \\
94 \\
P\end{array}$ & $\begin{array}{l}597 C \\
9-1 \\
94 \\
P\end{array}$ & $\begin{array}{l}597 C \\
9-1 \\
94 \\
P\end{array}$ & $\begin{array}{c}597 \mathrm{C} \\
9-1 \\
129 \\
\mathrm{P}\end{array}$ \\
\hline $\mathrm{SiO}_{2}$ & 51.86 & 51.89 & 52.10 & 51.72 & 51.04 & 51.09 & 51.17 & 51.19 & 51.74 & 50.94 & 51.77 & 52.06 & 52.70 & 51.87 & 51.10 & 50.87 & 50.13 & 51.20 & 51.03 & 52.77 & 50.47 \\
\hline $\mathrm{TiO}_{2}^{-}$ & 0.67 & 0.70 & 0.71 & 0.77 & 0.78 & 0.73 & 0.66 & 0.62 & 0.74 & 0.8 & 0.72 & 0.64 & 0.48 & 0.62 & 0.69 & 0.69 & 0.91 & 0.67 & 0.73 & 0.41 & 0.74 \\
\hline $\mathrm{Al}_{2} \mathrm{O}_{3}$ & 3.62 & 3.77 & 2.48 & 2.95 & 3.01 & 1.55 & 2.67 & 1.32 & 2.22 & 1.77 & 1.55 & 2.84 & 2.07 & 2.7 & 1.59 & 1.40 & 2.33 & 3.07 & 2.87 & 1.63 & 1.24 \\
\hline $\mathrm{FeO}$ & 7.85 & 5.99 & 8.35 & 8.90 & 8.56 & 17.74 & 8.21 & 15.66 & 12.14 & 15.18 & 16.21 & 8.31 & 9.10 & 8.86 & 17.28 & 18.15 & 12.85 & 7.74 & 7.91 & 8.71 & 21.27 \\
\hline $\mathrm{MnO}$ & 0.22 & 0.16 & 0.24 & 0.23 & 0.25 & 0.50 & 0.22 & 0.42 & 0.31 & 0.4 & 0.45 & 0.24 & 0.27 & 0.25 & 0.48 & 0.51 & 0.31 & 0.24 & 0.22 & 0.27 & 0.57 \\
\hline $\mathrm{MgO}$ & 16.52 & 15.96 & 16.35 & 16.64 & 16.20 & 14.63 & 16.41 & 14.78 & 15.68 & 12.73 & 14.20 & 16.88 & 18.24 & 16.87 & 14.86 & 14.29 & 14.02 & 16.99 & 15.91 & 18.97 & 10.54 \\
\hline $\mathrm{CaO}$ & 19.47 & 21.11 & 19.58 & 18.60 & 18.99 & 14.32 & 19.59 & 15.92 & 17.33 & 18.31 & 15.72 & 18.93 & 16.92 & 18.31 & 14.58 & 14.30 & 18.90 & 19.12 & 20.60 & 16.35 & 15.43 \\
\hline $\mathrm{Na}_{2} \mathrm{O}$ & 0.24 & 0.19 & 0.25 & 0.23 & 0.20 & 0.23 & 0.23 & 0.21 & 0.27 & 0.30 & 0.28 & 0.21 & 0.21 & 0.25 & 0.23 & 0.27 & 0.31 & 0.23 & 0.24 & 0.18 & 0.24 \\
\hline $\mathrm{Cr}_{2} \mathrm{O}_{3}$ & 0.21 & 0.55 & 0.03 & 0.10 & 0.14 & 0.00 & 0.07 & 0.00 & 0.00 & 0.00 & 0.00 & 0.10 & 0.07 & 0.09 & 0.00 & 0.00 & 0.00 & 0.10 & 0.05 & 0.09 & 0.00 \\
\hline Total & 100.66 & 100.32 & 100.09 & 100.14 & 99.17 & 100.79 & 99.23 & 100.12 & 100,43 & 100.51 & 100.90 & 100.21 & 100.06 & 99.88 & 100.81 & 100.48 & 99.76 & 99.36 & 99.56 & 99.38 & 100.50 \\
\hline $\mathrm{Ca}$ & 40 & & & & 35 & & & & & & & & 3. & 3 & 29 & 29 & 39 & 39. & 42. & 33. & 33.0 \\
\hline $\mathrm{Mg}$ & 47.3 & 46.6 & 46 & 47 & 46.8 & 42 & 46. & 42 & 4 & 37 & 41 & 48 & 51. & 48. & 42. & 41.1 & 40.3 & 48.4 & 45.3 & 53.3 & 31.4 \\
\hline $\mathrm{Fe}$ & 12.6 & 9.4 & 13.3 & 14.3 & 13.1 & 28.5 & 13.1 & 25.1 & 19.5 & 24.8 & 26.3 & 13.3 & 14.4 & 14.2 & 27.7 & 29.3 & 20.7 & 12.4 & 12.6 & 13.7 & 35.6 \\
\hline
\end{tabular}

\section{Appendix D (continued).}

\begin{tabular}{|c|c|c|c|c|c|c|c|c|c|c|c|c|c|c|c|c|c|c|c|c|c|}
\hline & $597 \mathrm{C}$ & $597 \mathrm{C}$ & $597 \mathrm{C}$ & $597 \mathrm{C}$ & $597 \mathrm{C}$ & $597 \mathrm{C}$ & $597 \mathrm{C}$ & $597 \mathrm{C}$ & $597 \mathrm{C}$ & $597 \mathrm{C}$ & $597 \mathrm{C}$ & $597 \mathrm{C}$ & $597 \mathrm{C}$ & $597 \mathrm{C}$ & $597 \mathrm{C}$ & $597 \mathrm{C}$ & $597 \mathrm{C}$ & $597 \mathrm{C}$ & $597 \mathrm{C}$ & $597 \mathrm{C}$ & $597 \mathrm{C}$ \\
\hline Core-Sec. & $7-2$ & $7-2$ & 7.3 & $7-3$ & $7-3$ & $7-5$ & $7-5$ & 7.5 & $8-4$ & 8.4 & 8.4 & $8-5$ & $8-5$ & 8.5 & $8-6$ & $8-6$ & $8-6$ & $9-1$ & $9-1$ & $9-1$ & $9-1$ \\
\hline $\begin{array}{l}\text { Position, } \mathrm{cm} \\
\text { Petrology }\end{array}$ & 136 & 136 & 122 & 122 & 122 & 90 & 90 & 90 & 23 & 23 & 23 & 49 & 49 & 49 & 56 & 56 & 56 & 94 & 94 & 94 & 129 \\
\hline $\mathrm{SiO}_{2}$ & 51.37 & 49.57 & 52.99 & 49.87 & 50.39 & 49.62 & 54.36 & 51.87 & 50.11 & 51.75 & 52.93 & 54.33 & 53.94 & 50.79 & 53.41 & 54.88 & 52.61 & 52.09 & 53.09 & 54.49 & 56.38 \\
\hline $\mathrm{Al}_{2} \mathrm{O}_{3}$ & 30.45 & 31.81 & 28.88 & 31.63 & 30.93 & 31.64 & 28.53 & 30.53 & 30.88 & 29.34 & 28.69 & 28.60 & 28.12 & 30.10 & 29.55 & 28.50 & 29.89 & 29.50 & 29.31 & 27.72 & 27.37 \\
\hline $\mathrm{FeO}-$ & 0.65 & 0.58 & 1.14 & 0.56 & 0.69 & 0.52 & 0.84 & 0.62 & 0.68 & 0.87 & 0.86 & 0.87 & 0.91 & 0.68 & 0.82 & 0.90 & 0.80 & 0.86 & 0.89 & 0.84 & 0.83 \\
\hline $\mathrm{CaO}$ & 14.50 & 15.76 & 13.08 & 15.80 & 15.02 & 15.81 & 11.97 & 14.32 & 14.96 & 13.19 & 12.30 & 11.95 & 11.90 & 14.16 & 12.78 & 11.65 & 13.20 & 13.27 & 13.13 & 11.25 & 10.74 \\
\hline $\mathrm{Na}_{2} \mathrm{O}$ & 3.29 & 2.59 & 4.13 & 2.72 & 3.01 & 2.68 & 4.74 & 3.45 & 3.24 & 4.18 & 4.5 & 4.73 & 4.75 & 3.49 & 4.29 & 4.97 & 4.15 & 4.06 & 4.14 & 5.21 & 5,46 \\
\hline $\mathrm{K}_{2} \mathrm{O}$ & 0.01 & 0.01 & 0.08 & 0.01 & 0.01 & 0.01 & 0.05 & 0.01 & 0.01 & 0.02 & 0.04 & 0.05 & 0.04 & 0.01 & 0.04 & 0.08 & 0.04 & 0.04 & 0.04 & 0.05 & 0.05 \\
\hline Total & 100.27 & 100.32 & 100.30 & 100.59 & 100.05 & 100.28 & 100.49 & 100.80 & 99.88 & 99.35 & 99.38 & 100.53 & 99.66 & 99.23 & 100.89 & 100.98 & 100.69 & 99.82 & 100.60 & 99.56 & 100.83 \\
\hline An & 70.8 & 77.0 & 63.4 & 76.2 & 73.3 & 76.5 & 58.1 & 69.6 & 71.8 & 63.5 & 59.7 & 58.1 & 58.0 & 69.1 & 62.1 & 56.2 & 63.6 & 64.2 & 63.5 & 54.3 & 51.9 \\
\hline
\end{tabular}


Appendix B (continued).

\begin{tabular}{|c|c|c|c|c|c|c|c|c|c|c|c|c|c|c|c|c|c|c|c|c|c|}
\hline $\begin{array}{c}597 \mathrm{C} \\
81.1 \\
119\end{array}$ & $\begin{array}{c}597 \mathrm{C} \\
8-2 \\
43\end{array}$ & $\begin{array}{c}597 \mathrm{C} \\
8.2 \\
85\end{array}$ & $\begin{array}{c}597 \mathrm{C} \\
8 .-3 \\
18\end{array}$ & $\begin{array}{c}597 \mathrm{C} \\
8.3 \\
118\end{array}$ & $\begin{array}{c}597 \mathrm{C} \\
8.4 \\
23\end{array}$ & $\begin{array}{c}597 \mathrm{C} \\
844 \\
109\end{array}$ & $\begin{array}{c}597 \mathrm{C} \\
8-5 \\
49\end{array}$ & $\begin{array}{c}597 \mathrm{C} \\
8-6 \\
56\end{array}$ & $\begin{array}{c}597 \mathrm{C} \\
8-7 \\
6\end{array}$ & $\begin{array}{l}597 \mathrm{C} \\
9 \cdot 1 \\
94\end{array}$ & $\begin{array}{c}597 \mathrm{C} \\
91 \\
129\end{array}$ & $\begin{array}{c}597 \mathrm{C} \\
9-2 \\
8\end{array}$ & $\begin{array}{c}597 \mathrm{C} \\
9.3 \\
57\end{array}$ & $\begin{array}{c}397 \mathrm{C} \\
9.4 \\
93\end{array}$ & $\begin{array}{l}597 \mathrm{C} \\
10-1 \\
119\end{array}$ & $\begin{array}{c}597 \mathrm{C} \\
10-2 \\
33\end{array}$ & $\begin{array}{c}597 \mathrm{C} \\
10-2 \\
65\end{array}$ & $\begin{array}{l}597 \mathrm{C} \\
10-2 \\
102\end{array}$ & $\begin{array}{l}597 \mathrm{C} \\
10-2 \\
119\end{array}$ & $\begin{array}{l}597 C \\
10-2 \\
128\end{array}$ & $\begin{array}{c}597 \mathrm{C} \\
10-3 \\
6\end{array}$ \\
\hline 50.19 & 50.62 & 49.95 & 49.53 & 50.02 & 50.33 & 50.23 & 50.23 & 50.67 & 50.71 & 67 & 50.25 & 49.94 & & 9 & 50.26 & .18 & 16 & 49.85 & 50.05 & 49.88 & \\
\hline 1.42 & 1.46 & 1.47 & 1.53 & 1.59 & & 1.50 & 1.40 & 1.54 & .55 & & 1.54 & 1.57 & & & 1.38 & 1.34 & 18 & 1.54 & & 1.19 & $4 \%$ \\
\hline 13 & 13.95 & 13 & 13 & 13 & 14 & 13 & 13 & 1. & & & & & & & 13.74 & & & & & 65 & 14.19 \\
\hline 12. & 12.67 & 12 & 12.92 & 12 & 12.42 & 13.04 & 12.19 & 12 & 3 & 5 & & & & & 12.32 & 9 & 16 & 5 & & 25 & 10.72 \\
\hline & & & & & & 0.18 & & & & & 19 & 0.20 & 18 & & 18 & 17 & 20 & 19 & 17 & 18 & 17 \\
\hline & 7. & & & & & & & & & & 5 & 6.99 & & & 7.53 & 7. & & & 21 & 8.13 & 8. \\
\hline 11. & 11. & 11.20 & 11 & 11 & 11 & 11.88 & 11 & 11 & 11.36 & 11.14 & 11.14 & 11.06 & 10.7 & 11.39 & 11.59 & 11.76 & 11 & & 12.32 & 12.25 & 12. \\
\hline 2. & 2. & 2. & 2. & 2 & & 2 & & & & & & & & & & & & & & & \\
\hline${ }_{0}^{0}$. & ${ }_{0}^{0}$. & 0 & 0. & $\begin{array}{l}0 \\
0 \\
0\end{array}$ & & 0 & & & & & & & & & & & & & & & .04 \\
\hline $\begin{array}{l}0.12 \\
0.13\end{array}$ & $\begin{array}{l}0.17 \\
0.17\end{array}$ & $\begin{array}{l}0.12 \\
0.42\end{array}$ & $\begin{array}{l}0.12 \\
0.40\end{array}$ & $\begin{array}{l}0.1 \\
0.2\end{array}$ & 0 & . & $\begin{array}{l}0.14 \\
0.39\end{array}$ & & & & $\begin{array}{l}0.16 \\
0009\end{array}$ & & & & & & & & & 0.08 & .12 \\
\hline 100.24 & 10.96 & 99.76 & 98.82 & 99.34 & 100.18 & 100.96 & 99.80 & 99.41 & 99.94 & 100.01 & 100.30 & 0.03 & $\begin{array}{r}0.21 \\
100.64\end{array}$ & $\begin{array}{r}0.42 \\
101.49\end{array}$ & 0.17 & 9.29 & 99.39 & 0.29 & 0.16 & 0.64 & \\
\hline 79 & 87 & 88 & 8 & 94 & 93 & 8 & 83 & 89 & 8 & 9 & 90 & 95 & 96 & & & & & 89 & & & \\
\hline 30 & 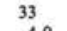 & 34 & & 37 & & & & 30 & 35 & 35 & & 35 & 36 & 35 & & 3 & & & & & \\
\hline $\begin{array}{l}3.8 \\
3.2\end{array}$ & $\begin{array}{l}4.0 \\
3.8\end{array}$ & 4.5 & 4 & $\begin{array}{l}4.6 \\
3.1\end{array}$ & 4. & 4 & 4.6 & 4.9 & 4.8 & 5.2 & 5.2 & 5.0 & 5.3 & 3.5 & 3.9 & 4.0 & 4. & 4.8 & 3. & 3.5 & 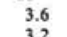 \\
\hline 80 & & 83 & $\begin{array}{l}5 . \\
82\end{array}$ & 9.1 & $\begin{array}{l}4 . \\
87\end{array}$ & 84 & 83. & $\begin{array}{l}3.0 \\
88\end{array}$ & $\begin{array}{r}2.8 \\
83\end{array}$ & 4.0 & 4.0 & 3.3 & 3.4 & 95.2 & 3.0 & 3.1 & $4 .(4$ & 21 & 78 & 3.6 & $\begin{array}{c}3.2 \\
78\end{array}$ \\
\hline 172 & $\begin{array}{l}142 \\
145\end{array}$ & 21 & 13 & & 87 & 84 & $\begin{array}{r}83 \\
124\end{array}$ & 88 & 8 & 8 & $\begin{array}{l}83 \\
88\end{array}$ & 87 & $\begin{array}{l}88 \\
84\end{array}$ & & 81 & 82 & 82 & 83 & 78 & & $\begin{array}{c}78 \\
0\end{array}$ \\
\hline 72 & & & & & & 120 & & & 9 & 8 & & & $\begin{array}{l}84 \\
63\end{array}$ & & & & & $\begin{array}{r}0 \\
42\end{array}$ & & & 100 \\
\hline 43 & 352 & 3. & 4 & 4 & & & 4 & 43 & & & & 3 & & & & & 0 & 40 & & & 0 \\
\hline 132 & 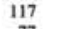 & & & & & & & & & & & 128 & & & & 141 & & & & & 175 \\
\hline 83 & 77 & 90 & sos & 86 & 81 & 91 & 82 & 81 & 88 & 80 & 80 & 90 & 87 & on & . & 74 & 95 & 92 & 67 & 77 & 70 \\
\hline 0. & 0. & & & & & & & & & 0 . & 0. & 0. & 0. & & & $0 . c$ & & & 1. & 0. & 0.00 \\
\hline & $\begin{array}{l}1 \\
24\end{array}$ & & & & & & & & & & & & & & & & & & & & \\
\hline 26 . & & & & & & & & & & & & & & & & & & & & & $\begin{array}{l}18.70 \\
28.69\end{array}$ \\
\hline 0 & & & & & & & & & & & & & & & & & & & & & \\
\hline & & & & & & & & & & & & & & & & & & & & & 38 \\
\hline & & & & & & & & & & & & & 14 & & & & & & & & 14 \\
\hline 2. & & & & & & & & & & & & & & & & & & & & & \\
\hline $\begin{array}{l}2.6 \\
2.7\end{array}$ & 2. & & & & & & & & & & & & & & & & & & & & \\
\hline $\begin{array}{l}2.728 \\
0.28\end{array}$ & 0.39 & 0.28 & & & & & & & & & & & & & & & & & & & \\
\hline 0.28 & 0.39 & 0.28 & 0.2 & 0.3 & 0.32 & 0. & 0.3 & 0.2 & 0. & 0. & 0.37 & 0.2 & 0.37 & 0.32 & 0.3 & 0.35 & 0.42 & 0.35 & 0.28 & 0.19 & \\
\hline
\end{tabular}

Appendix C (continued).

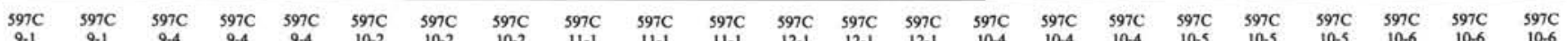

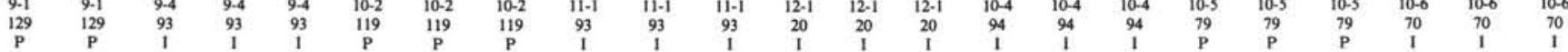

\begin{tabular}{|c|c|c|c|c|c|c|c|c|c|c|c|c|c|c|c|c|c|c|c|c|c|c|}
\hline 52.81 & 51.47 & 51.19 & 51.47 & 52.11 & 51.83 & 51.40 & 52.67 & 52.08 & 53.50 & 54.90 & 52.53 & 52.92 & 54.29 & 52,19 & 52.83 & 52.16 & 52.56 & 53.37 & 53.24 & 51.98 & 52.73 & 53.52 \\
\hline 0.62 & 0.85 & 0.81 & 0.69 & 0.56 & 0.62 & 0.72 & 0.43 & 0.61 & 0.38 & 0.25 & 0.54 & 0.38 & 0.27 & 0.61 & 0.50 & 0.56 & 0.51 & 0.47 & 0.47 & 0.54 & 0.45 & 0.41 \\
\hline 2.29 & 1.83 & 1.47 & 2.10 & 2.30 & 1.24 & 2.28 & 2.30 & 1.08 & 0.62 & 0.65 & 0.99 & 0.58 & 0.73 & 1.24 & 1.43 & 2.27 & 2.57 & 1.55 & 2.51 & 2.04 & 2.46 & 1.71 \\
\hline 9.41 & 14.46 & 17.05 & 11.57 & 8.82 & 16.23 & 11.34 & 6.23 & 19.58 & 20.90 & 16.75 & 18.90 & 20.98 & 16.43 & 15.64 & 10.77 & 8.13 & 6.42 & 8.88 & 6.63 & 7.92 & 5.78 & 7.33 \\
\hline 0.28 & $\begin{array}{r}0.39 \\
\end{array}$ & 0.46 & 0.31 & 0.23 & 0.47 & 0.33 & 0.16 & 0.52 & 0.52 & 0.45 & 0.51 & 0.54 & 0.42 & 0.43 & 0.31 & 0.22 & 0.19 & 0.28 & 0.20 & 0.24 & 0.17 & 0.20 \\
\hline 17.15 & 13.63 & 12.91 & 15.03 & 16.62 & 14.93 & 15.93 & 17.08 & 19.21 & 20.20 & 24.00 & 19.89 & 20.21 & 23.73 & 14.84 & 16.25 & 16.15 & 16.86 & 17.37 & 17.36 & 16.41 & 16.95 & 17.52 \\
\hline 17.84 & 17.97 & 16.77 & 18.43 & 18.88 & 15.30 & 17.82 & 20.72 & 6.83 & 4.47 & 3.92 & 5.88 & 3.96 & 4.02 & 14.95 & 17.45 & 19.31 & 19.99 & 18.03 & 19.42 & 19.80 & 20.90 & 19.96 \\
\hline 0.26 & 0.26 & 0.27 & 0.24 & 0.25 & 0.21 & 0.25 & 0.19 & 0.11 & 0.04 & 0.07 & 0.11 & 0.09 & 0.05 & 0.23 & 0.20 & 1.21 & 0.21 & 0.28 & 0.22 & 0.21 & 0.21 & 0.18 \\
\hline 0.03 & 0.00 & 0.00 & 0.02 & 0.05 & 0.00 & 0.00 & 0.26 & 0.00 & 0.00 & 0.00 & 0.00 & 0.00 & 0.00 & 0.02 & 0.02 & 0.03 & 0.24 & 0.02 & 0.22 & 0.03 & 0.40 & 0.07 \\
\hline 100.69 & 100.86 & 100.93 & 99.86 & 99.82 & 100.83 & 100.07 & 100.04 & 100.02 & 100.63 & 100.99 & 99.35 & 99.66 & 99.94 & 100.15 & 99.76 & 100.04 & 99.55 & 100.25 & 100.27 & 99.17 & 100.05 & 100.90 \\
\hline 36.4 & 37 & 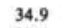 & II & 38.6 & & & & & 9 & 7. & 18 & 8. & 8 & & 36 & 40 & 41 & 36 & 39 & 40. & 42.6 & 39.9 \\
\hline 48.6 & 39.3 & .4 & 43.2 & 47,3 & 42.6 & 45.4 & 36.5 & 54.7 & 54.5 & 66.3 & 57.2 & 50.0 & 66.2 & 43.2 & 46.6 & 46.7 & 48.4 & 49.2 & 49.6 & 46.8 & 48.1 & 48.7 \\
\hline 15.0 & 23.4 & 27.7 & 18.7 & 14.1 & 26.0 & 18.1 & 9.8 & 31.3 & 33.4 & 26.0 & 30.5 & 33.8 & 25.7 & 25.5 & 17.3 & 13.2 & 10.3 & 14.1 & 10.6 & 12.7 & 9.3 & 11.4 \\
\hline
\end{tabular}

\section{Appendix D (continued).}

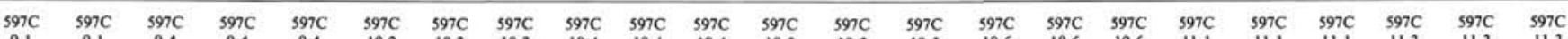

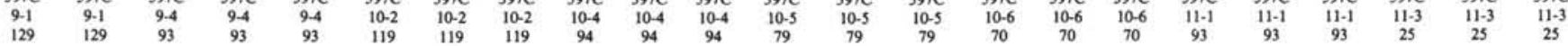

\begin{tabular}{rrrrrrrrrrrrrrrrrrrrrrrr}
\hline 56.12 & 53.42 & 53.15 & 51.91 & 53.19 & 50.81 & 53.56 & 53.66 & 55.95 & 48.19 & 53.22 & 52.15 & 52.23 & 52.88 & 54.23 & 51.51 & 51.25 & 50.51 & 50.56 & 52.20 & 51.93 & 50.92 & 49.48 \\
27.42 & 29.09 & 29.35 & 30.15 & 29.10 & 30.60 & 28.40 & 28.63 & 26.60 & 32.06 & 28.50 & 30.23 & 30.26 & 29.75 & 28.69 & 30.03 & 30.23 & 30.82 & 31.11 & 29.58 & 30.13 & 30.85 & 31.84 \\
0.80 & 0.83 & 0.83 & 0.79 & 0.86 & 0.77 & 0.96 & 0.91 & 0.79 & 0.63 & 0.80 & 0.75 & 0.70 & 0.70 & 0.83 & 0.77 & 0.72 & 0.80 & 0.76 & 0.75 & 0.79 & 0.83 & 0.79 \\
10.81 & 12.85 & 12.62 & 13.61 & 12.60 & 14.67 & 12.44 & 12.44 & 10.28 & 16.37 & 12.61 & 13.69 & 13.77 & 13.25 & 12.39 & 14.17 & 14.22 & 14.59 & 14.90 & 13.33 & 13.81 & 14.53 & 15.50 \\
5.37 & 4.34 & 4.36 & 3.84 & 4.43 & 3.17 & 4.48 & 4.43 & 5.36 & 2.06 & 4.16 & 3.81 & 3.75 & 3.99 & 4.62 & 3.49 & 3.47 & 3.32 & 3.18 & 3.97 & 3.68 & 3.27 & 2.71 \\
0.05 & 0.02 & 0.04 & 0.02 & 0.04 & 0.01 & 0.02 & 0.04 & 0.05 & 0.01 & 0.04 & 0.02 & 0.01 & 0.02 & 0.04 & 0.02 & 0.02 & 0.02 & 0.02 & 0.04 & 0.02 & 0.01 & 0.01 \\
100.57 & 100.55 & 100.35 & 100.32 & 100.22 & 100.03 & 99.86 & 100.11 & 99.03 & 99.32 & 99.33 & 100.65 & 100.72 & 100.59 & 100.80 & 99.99 & 99.91 & 100.06 & 100.53 & 99.87 & 100.36 & 100.41 & 100.33
\end{tabular}

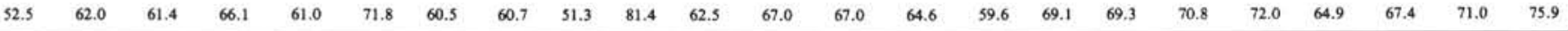


Appendix B (continued).

\begin{tabular}{|c|c|c|c|c|c|c|c|c|c|c|c|c|c|c|c|c|c|c|c|}
\hline Hole & $597 \mathrm{C}$ & $597 \mathrm{C}$ & $597 \mathrm{C}$ & $597 \mathrm{C}$ & $597 \mathrm{C}$ & $597 \mathrm{C}$ & $597 \mathrm{C}$ & $597 \mathrm{C}$ & $597 \mathrm{C}$ & $597 \mathrm{C}$ & $597 \mathrm{C}$ & $597 \mathrm{C}$ & $597 \mathrm{C}$ & $599 \mathrm{~B}$ & $601 \mathrm{~B}$ & $601 B$ & $601 \mathrm{~B}$ & $601 B$ & $602 \mathrm{~B}$ \\
\hline Core-Sec. & $10-3$ & $10-4$ & $10-5$ & $10-5$ & $10-5$ & $10-6$ & $10-7$ & $11-1$ & $11-1$ & $11-3$ & $11-3$ & $11-4$ & 12.1 & $4-1$ & $2-1$ & 2.1 & 2.1 & 2.1 & 1.2 \\
\hline Position, $\mathrm{cm}$ & 80 & 94 & 55 & 74 & 79 & 70 & 67 & 74 & 93 & 25 & 128 & 73 & 20 & 14 & 16 & 43 & 69 & 105 & 99 \\
\hline $\mathrm{SiO}_{2}$ & 49.55 & 49.77 & 49.58 & 49.61 & 49.30 & 49.81 & 49.60 & 49.13 & 49.52 & 49.14 & 49.85 & 49.20 & 49.33 & 50.51 & 50.54 & 49.75 & 50.72 & 50.76 & 47.52 \\
\hline $\mathrm{TiO}_{2}$ & 0.97 & 0.82 & 0.70 & 0.71 & 0.86 & 1.01 & 0.91 & 0.90 & 0.93 & 0.84 & 0.85 & 0.85 & 1.05 & 1.17 & 2.73 & 2.58 & 2.71 & 2.62 & 3.00 \\
\hline $\mathrm{Al}_{2} \mathrm{O}_{3}$ & 14.48 & 15.71 & 16.35 & 16.49 & 15.77 & 15.56 & 16.36 & 16.81 & 17.04 & 16.98 & 16.36 & 16.40 & 14.49 & 14.95 & 13.30 & 12.68 & 13.36 & 12.93 & 15.57 \\
\hline $\mathrm{Fe}_{2} \mathrm{O}_{3}$ & 9.97 & 9.48 & 8.36 & 8.66 & 9.27 & 10.17 & 9.41 & 9.40 & 9.58 & 8.99 & 8.93 & 8.98 & 10.39 & 9.96 & 14.17 & 16.51 & 14.07 & 14.55 & 11.12 \\
\hline Mno & 0.17 & 0.16 & 0.14 & 0.14 & 0.15 & 0.15 & 0.14 & 0.14 & 0.14 & 0.14 & 0.14 & 0.14 & 0.17 & 0.16 & 0.21 & 0.25 & 0.22 & 0.21 & 0.18 \\
\hline $\mathrm{MgO}$ & 8.46 & 9.23 & 8.78 & 9.71 & 8.88 & 8.63 & 8.40 & 8.12 & 8.27 & 9.01 & 9.17 & 8.65 & 8.25 & 7.27 & 5.11 & 5.66 & 5.38 & 5.28 & 5.66 \\
\hline $\mathrm{CaO}$ & 13.41 & 13.11 & 13.67 & 13.30 & 13.07 & 12.69 & 13.07 & 12.80 & 12.88 & 13.49 & 13.78 & 13.20 & 12.55 & 12.43 & 10.11 & 9.84 & 9.89 & 9.70 & 8.87 \\
\hline $\mathrm{Na}_{2} \mathrm{O}$ & 1.84 & 2.10 & 1.85 & 2.23 & 1.77 & 1.97 & 1.99 & 2.00 & 1.96 & 2.43 & 2.31 & 2.11 & 2.11 & 2.93 & 2.60 & 2.83 & 3.19 & 2.78 & 4.31 \\
\hline $\mathrm{K}_{2} \mathrm{O}$ & 0.04 & 0.04 & 0.03 & 0.04 & 0.04 & 0.04 & 0.04 & 0.04 & 0.04 & 0.05 & 0.03 & 0.05 & 0.07 & 0.19 & 0.58 & 0.22 & 0.50 & 0.48 & 1.57 \\
\hline $\mathrm{P}_{2} \mathrm{O}_{5}$ & 0.12 & 0.05 & 0.06 & 0.12 & 0.09 & 0.08 & 0.08 & 0.08 & 0.13 & 0.10 & 0.08 & 0.08 & 0.09 & 0.09 & 0.31 & 0.23 & 0.29 & 0.28 & 0.67 \\
\hline Loิ & 0.73 & 0.77 & 0.81 & 1.18 & 0.77 & 0.57 & 0.54 & 0.70 & 0.75 & 0.64 & 0.61 & 0.58 & 0.58 & 0.42 & 0.14 & 0.10 & 0.41 & 0.61 & 1.09 \\
\hline Total & 99.74 & 101.24 & 100.33 & 102.19 & 99.97 & 100.68 & 100.54 & 100.12 & 101.24 & 101.81 & 102.11 & 100.24 & 99.08 & 100.08 & 99.80 & 100.65 & 100.74 & 100.20 & 99.56 \\
\hline $\mathrm{Zr}$ & 58 & 50 & 43 & 48 & 53 & 57 & 55 & 55 & 54 & 53 & 53 & 53 & 62 & 76 & 199 & 192 & 199 & 190 & 311 \\
\hline $\mathrm{Y}$ & 24 & 21 & 17 & 18 & 21 & 23 & 22 & 20 & 20 & 21 & 21 & 21 & 25 & 32 & 74 & 69 & 75 & 68 & 56 \\
\hline $\mathrm{Nb}$ & 3.8 & 3.6 & 3.4 & 3.5 & 3.9 & 3.8 & 3.7 & 3.8 & 3.3 & 3.8 & 4.2 & 4.0 & 4.1 & 2.1 & 4.1 & 4.9 & 4.6 & 4.4 & 42.0 \\
\hline Rb & 2.2 & 2.1 & 2.5 & 1.7 & 3.5 & 1.9 & 1.6 & 2.9 & 1.4 & 2.7 & 2.9 & 2.4 & 2.5 & 7.2 & 6.2 & 3.0 & 7.7 & 8.0 & 19.6 \\
\hline Sr & 78 & 77 & 77 & 77 & 78 & 80 & 88 & 83 & 85 & 81 & 79 & 80 & 79 & 94 & 148 & 112 & 141 & 124 & 340 \\
\hline $\mathrm{Cr}$ & 0 & 344 & 389 & 383 & 506 & 382 & 397 & 386 & 374 & 476 & 545 & 529 & 319 & 264 & 44 & 74 & 35 & 52 & 135 \\
\hline $\mathrm{Ni}$ & 112 & 128 & 128 & 140 & 124 & 119 & 118 & 100 & 112 & 127 & 108 & 118 & 100 & 82 & 69 & 57 & 58 & 32 & 113 \\
\hline $\mathrm{v}$ & 0 & 259 & 223 & 229 & 270 & 297 & 264 & 279 & 260 & 241 & 255 & 246 & 318 & 253 & 476 & 427 & 468 & 450 & 257 \\
\hline $\mathrm{Cu}$ & 142 & 125 & 94 & 113 & 118 & 124 & 112 & 102 & 95 & 93 & 110 & 82 & 135 & 102 & 78 & 81 & 89 & 55 & 53 \\
\hline $\mathrm{Zn}$ & 71 & 58 & 54 & si & 57 & 60 & 56 & 60 & 60 & 53 & 52 & 54 & 64 & 84 & 46 & 138 & 148 & 116 & 102 \\
\hline Q & 0.00 & 0.00 & 0.00 & 0.00 & 0.00 & 0.00 & 0.00 & 0.00 & 0.00 & 0.00 & 0.00 & 0.00 & 0.00 & 0.00 & 3.85 & 1.30 & 1.23 & 3.57 & 0.00 \\
\hline Or & 0.24 & 0.24 & 0.18 & 0.24 & 0.24 & 0.24 & 0.24 & 0.24 & 0.24 & 0.30 & 0.18 & 0.30 & 0.41 & 1.12 & 3.43 & 1.30 & 2.95 & 2.84 & 9.28 \\
\hline $\mathrm{Ab}$ & 15.57 & 17.77 & 15.65 & 18.87 & 14.98 & 16.67 & 16.84 & 16.92 & 16.58 & 20.56 & 19.55 & 17.85 & 17.85 & 24.79 & 22.00 & 23.95 & 26.99 & 23.52 & 25.99 \\
\hline An & 31.14 & 33.33 & 36.23 & 34.87 & 34.97 & 33.50 & 35.60 & 36.78 & 37.59 & 35.28 & 34.19 & 35.14 & 29.87 & 27.09 & 22.91 & 21.25 & 20.67 & 21.39 & 18.51 \\
\hline $\mathrm{Ne}$ & 0.00 & 0.00 & 0.00 & 0.00 & 0.00 & 0.00 & 0.00 & 0.00 & 0.00 & 0.00 & 0.00 & 0.00 & 0.00 & 0.00 & 0.00 & 0.00 & 0.00 & 0.00 & 5.68 \\
\hline $\mathrm{Di}$ & 28.09 & 25.38 & 25.18 & 24.44 & 23.69 & 23.48 & 23.27 & 21.25 & 20.65 & 25.03 & 27.17 & 24.12 & 25.86 & 27.69 & 20.93 & 21.72 & 21.96 & 20.68 & 17.26 \\
\hline Hy & 18.66 & 12.45 & 15.06 & 7.35 & 18,84 & 19.24 & 16.26 & 16.24 & 17.55 & 1.64 & 5.24 & 11.20 & 17.32 & 7.64 & 16.34 & 20.60 & 16.45 & 17.56 & 0.00 \\
\hline OI & 0.18 & 6.76 & 3.22 & 10.99 & 1.84 & 1.81 & 3.03 & 3.25 & 2.91 & 13.80 & 10.68 & 6.54 & 1.84 & 5.89 & 0.00 & 0.00 & 0.00 & 0.00 & 11.15 \\
\hline Mt & 2.17 & 2.06 & 1.82 & 1.88 & 2.02 & 2.21 & 2.05 & 2.04 & 2.08 & 1.96 & 1.94 & 1.95 & 2.26 & 2.17 & 3.08 & 3.59 & 3.06 & 3.16 & 2.42 \\
\hline II & 1,84 & 1.56 & 1.33 & 1.35 & 1.63 & 1.92 & 1.73 & 1.71 & 1.77 & 1.60 & 1.61 & 1.61 & 1.99 & 2.22 & 5.18 & 4.90 & 5.15 & 4.98 & 5.70 \\
\hline Ap & 0.28 & 0.12 & 0.14 & 0.28 & 0.21 & 0.19 & 0.19 & 0.19 & 0.30 & 0.23 & 0.19 & 0.19 & 0.21 & 0.21 & 0.72 & 0.53 & 0.67 & 0.65 & 1.55 \\
\hline
\end{tabular}

Appendix C (continued).

\begin{tabular}{|c|c|c|c|c|c|c|c|c|c|c|c|c|c|c|c|c|c|c|c|}
\hline & $597 \mathrm{C}$ & $597 \mathrm{C}$ & $597 \mathrm{C}$ & $597 \mathrm{C}$ & $597 \mathrm{C}$ & $597 \mathrm{C}$ & $597 \mathrm{C}$ & $597 \mathrm{C}$ & $597 \mathrm{C}$ & $597 \mathrm{C}$ & $597 \mathrm{C}$ & $599 \mathrm{~B}$ & $599 \mathrm{~B}$ & $599 \mathrm{~B}$ & $601 \mathrm{~B}$ & 6018 & 6018 & $602 \mathrm{~B}$ & $602 \mathrm{~B}$ \\
\hline Core-Sec. & $11-1$ & $11-1$ & $11-1$ & $11-3$ & $11-3$ & $11-3$ & $11-3$ & $11-3$ & $12-1$ & $12-1$ & $12-1$ & $4-1$ & 41 & $4-1$ & 2.1 & $2-1$ & $2-1$ & 1.2 & $1-2$ \\
\hline Position, cm & 93 & 93 & 93 & 25 & 25 & 25 & 25 & 25 & 20 & 20 & 20 & 67 & 67 & 67 & 69 & 69 & 69 & 99 & 99 \\
\hline Petrology $y^{\mathrm{a}}$ & $\mathbf{P}$ & P & P & v & I & I & 1 & 1 & 1 & 1 & I & 1 & 1 & 1 & 1 & 1 & 1 & 1 & p \\
\hline $\mathrm{SiO}_{2}$ & 53.38 & 52.90 & 52.70 & 53.43 & 52.86 & 51.97 & 52.84 & 53.08 & 51.82 & 52.46 & 52.27 & 50.84 & 51.17 & 51.99 & $\$ 2.13$ & 51.51 & 51.45 & 43.45 & 44,74 \\
\hline $\mathrm{TiO}_{2}$ & 0.34 & 0.38 & 0.40 & 0.43 & 0.45 & 0.45 & 0.40 & 0.47 & 0.73 & 0.38 & 0.54 & 0.81 & 1.00 & 0.7 & 0. & 1.06 & 1.10 & 4.95 & 4.61 \\
\hline $\mathrm{Al}_{2} \mathrm{O}_{3}$ & 2.16 & 1.89 & 2.22 & 2.44 & 2.31 & 2.92 & 2.01 & 1.75 & 1.93 & 2.32 & 1.68 & 3.88 & 3.43 & 3.0 & 2.70 & 2.90 & 2.83 & 7.96 & 7. \\
\hline $\mathrm{FeO}$ & 5.57 & 5.63 & 5.96 & 5.89 & 6.58 & 5.78 & 5.89 & 7.69 & 10.61 & 5.78 & 8.89 & 6.98 & 11.75 & 7.6 & 9.4 & 10.02 & 9.78 & 9.13 & 9.0 \\
\hline Mno & 0.16 & 0.16 & 0.20 & 0.16 & & 0.16 & & 0.22 & 0.27 & 0.14 & & 0. & & & & & 0.25 & 0.19 & $0.1 \quad-1$ \\
\hline $\mathrm{MgO}$ & 17.86 & 17.53 & 17.38 & 17.07 & 17.11 & 16.78 & 17.15 & 16.95 & 15.82 & 17.07 & 16.79 & 16.60 & 15.67 & 17.1 & 16.2 & 16.30 & 15.86 & 10.86 & 11.22 \\
\hline $\mathrm{CaC}$ & 20.34 & 20.67 & 20.33 & 20.74 & 20.07 & 20.59 & 20.73 & 19.70 & 18.45 & 20.71 & 18.82 & 19.48 & 16.39 & 18. & 18. & 17. & 18.68 & 22.03 & 22.13 \\
\hline $\mathrm{Na}_{2}$ & 0.22 & 0.19 & 0.21 & 0.19 & 0.21 & 0.19 & 0.19 & 0.24 & 0.25 & 0.21 & 0.25 & 0.27 & 0.47 & 0. & 0. & 0.3 & 0.30 & 0.61 & 0.59 \\
\hline $\mathrm{Cr}_{2} \mathrm{O}_{3}$ & 0.69 & 0.45 & 0.45 & 0.45 & 0.17 & 0.66 & 0.28 & 0.00 & 0.00 & 0.48 & 0.00 & 0.16 & 0.02 & 0.12 & 0.05 & 0.05 & 0.05 & 0.09 & 0.09 \\
\hline Total & 100.72 & 99.80 & 99.85 & 100.80 & 99.93 & 99.50 & 99.68 & 100.10 & 99.88 & 99.55 & 99.49 & 99.22 & 100.24 & 99.69 & 100.26 & 100.38 & 100.30 & 99.27 & 100.10 \\
\hline c & & & & & & & & & & & & & 35 & 38 & 37 & 37 & 38 & 49 & 49.4 \\
\hline $\mathrm{Mg}$ & 50.2 & 49.3 & 49.2 & 48.4 & 4 & 48.2 & 48.5 & & 4 & 48 & 4 & 48 & 45 & 49 & 47 & 46 & 45 & 34.1 & 34.9 \\
\hline $\mathrm{Fe}$ & 8.8 & 8.9 & 9.5 & 9.4 & 10.5 & 9.3 & 9.4 & 12.2 & 17.0 & 9.2 & 14.1 & 11.3 & 19.6 & 12.4 & 15.3 & 16.1 & 15.8 & 16.1 & 15.7 \\
\hline
\end{tabular}

Appendix D (continued).

\begin{tabular}{|c|c|c|c|c|c|c|c|c|c|c|c|c|c|c|c|c|c|c|c|c|}
\hline Hole & $597 \mathrm{C}$ & $597 \mathrm{C}$ & $597 \mathrm{C}$ & 599B & $599 \mathrm{~B}$ & $599 \mathrm{~B}$ & $599 \mathrm{~B}$ & $599 \mathrm{~B}$ & 599B & $601 B$ & 6018 & $601 \mathrm{~B}$ & $601 B$ & $601 B$ & 6018 & $601 B$ & $601 \mathrm{~B}$ & $602 \mathrm{~B}$ & $602 \mathrm{~B}$ & $602 B$ \\
\hline Core-Sec. & $12-1$ & $12-1$ & $12-1$ & $4-1$ & $4-1$ & $4-1$ & $4-1$ & $4-1$ & $4-1$ & $2-1$ & $2-1$ & $2-1$ & $2-t$ & $2-1$ & $2-1$ & $2-1$ & $2-1$ & $1-2$ & $1-2$ & $1-2$ \\
\hline $\begin{array}{l}\text { Position, cm } \\
\text { Petrology }\end{array}$ & 20 & 20 & 20 & 14 & 14 & 14 & 67 & 67 & 67 & 16 & 16 & 16 & 16 & 16 & $\begin{array}{c}43 \\
\mathrm{P}\end{array}$ & $\stackrel{43}{P}$ & $\begin{array}{c}43 \\
P\end{array}$ & 99 & 99 & 99 \\
\hline $\mathrm{SiO}_{2}$ & .58 & 47.7 & 54.49 & 52.01 & 51.99 & 52.5 & 51.1 & 51.22 & $\$ 1.1$ & 54.16 & 53. & 54.09 & 56.50 & 56.93 & 46.75 & 46.94 & 46.74 & 50.97 & 51.07 & 50.87 \\
\hline $\mathrm{Al}_{2} \mathrm{O}_{3}$ & 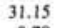 & 33.1 & 28.6 & 28.11 & 28.5 & 28.3 & 29. & 30.59 & 30. & 28.42 & 28. & 28.40 & 26.54 & 25.75 & 33.57 & 33.28 & 33.15 & 31.26 & 30.93 & 31.24 \\
\hline FeO & 0.79 & 0.70 & 0.83 & 1.01 & 0.80 & 0.89 & 1.28 & 0.53 & 0.63 & 0.70 & 0.65 & 0.70 & 1.12 & 1.18 & 0.52 & 0.46 & & 0.45 & 0.49 & 0.48 \\
\hline $\mathrm{Ca}$ & 15.14 & 17.0 & 12.04 & 14.01 & 13.0 & 12.71 & 13.2 & 14.47 & 14. & 12.05 & 12. & 11. & 9 & 9.39 & 15.90 & 16.79 & 17.90 & 14.40 & 14.19 & 14.20 \\
\hline $\mathrm{Na}_{2}$ & & 1. & 4. & 3.4 & 3. & 4. & & & & 4. & & 4. & & & & 1. & 1.40 & 3.37 & 3.49 & 3.48 \\
\hline $\mathrm{K}_{2} \mathrm{C}$ & 0.01 & 0.01 & 0.05 & 0.01 & 0.03 & 0.01 & 0.07 & 0.01 & 0.05 & 0.02 & 0.02 & 0.02 & 0.07 & 0.08 & 0.00 & 0.00 & 0.00 & 0.10 & 0.10 & 0.10 \\
\hline Total & 99.55 & 100.48 & 100.78 & 98.55 & 98.28 & 98.57 & 98.53 & 100.19 & 99.47 & 100.02 & 99.84 & 99.81 & 99.93 & 99.30 & 98.16 & 98.90 & 99.77 & 100.55 & 100.27 & 100.37 \\
\hline An & 74.4 & 83.4 & 58.3 & 69,4 & 65.0 & 63.2 & 66.2 & 70.3 & 68.8 & 58.7 & 59.3 & 58.0 & 48.9 & 48.3 & 87. & 87. & 87.5 & 69.8 & 68.8 & 68.8 \\
\hline
\end{tabular}


APPENDIX E

Reconnaissance Electron Microprobe Analyses (wt.\%) of Oxides from DSDP Leg 92 Basalts

\begin{tabular}{|c|c|c|c|c|c|c|c|c|c|c|c|c|c|c|c|c|c|c|}
\hline Hole & 597B & 597B & $597 \mathrm{~B}$ & 597B & $597 \mathrm{C}$ & $597 \mathrm{C}$ & $597 \mathrm{C}$ & $597 \mathrm{C}$ & $597 \mathrm{C}$ & $597 \mathrm{C}$ & $597 \mathrm{C}$ & $597 \mathrm{C}$ & $597 \mathrm{C}$ & $597 \mathrm{C}$ & $597 \mathrm{C}$ & $597 \mathrm{C}$ & $597 \mathrm{C}$ & $597 \mathrm{C}$ \\
\hline Core-Sec. & $3-1$ & $3-1$ & $3-1$ & $3-2$ & $3-2$ & $3-2$ & $3-2$ & $5-2$ & $5-2$ & $5-2$ & $7-1$ & $7-1$ & $7-2$ & $7-3$ & $7-3$ & $7-5$ & 7.5 & $7-5$ \\
\hline Position, $\mathrm{cm}$ & 16 & 16 & 16 & 27 & 20 & 20 & 20 & 12 & 12 & 12 & 53 & 53 & 136 & 122 & 122 & 90 & 90 & 90 \\
\hline $\mathrm{SiO}_{2}$ & 0.39 & 0.21 & 0.28 & 0.54 & 0.23 & 0.26 & 0.26 & 0.28 & 0.21 & 0.41 & 0.49 & 0.59 & 0.36 & 0.18 & 0.16 & 0.23 & 0.16 & 0.44 \\
\hline $\mathrm{TiO}_{2}$ & 21.85 & 20.54 & 20.68 & 21.66 & 18.33 & 17.87 & 19.33 & 20.65 & 21.29 & 22.40 & 21.14 & 23.13 & 20.42 & 20.00 & 21.30 & 21.76 & 20.64 & 21.08 \\
\hline $\mathrm{Al}_{2} \mathrm{O}_{3}$ & 1.72 & 1.87 & 1.92 & 1.69 & 2.25 & 2.53 & 1.60 & 2.20 & 1.75 & 1.76 & 2.19 & 1.98 & 1.97 & 1.80 & 1.15 & 1.10 & 1.83 & 1.75 \\
\hline $\mathrm{FeO}$ & 70.96 & 72.44 & 71.76 & 70.37 & 72.70 & 72.66 & 73.00 & 71.24 & 72.03 & 68.53 & 70.06 & 67.88 & 72.08 & 72.92 & 73.09 & 72.71 & 73.53 & 72.43 \\
\hline $\mathrm{MnO}$ & 0.57 & 0.51 & 0.50 & 0.53 & 0.47 & 0.48 & 0.55 & 0.47 & 0.50 & 0.53 & 0.59 & 0.50 & 0.53 & 0.37 & 0.60 & 0.58 & 0.60 & 0.58 \\
\hline $\mathrm{MgO}$ & 0.12 & 0.19 & 0.19 & 0.22 & 0.65 & 0.56 & 0.07 & 0.89 & 0.72 & 0.65 & 0.29 & 0.36 & 0.60 & 0.82 & 0.56 & 0.27 & 0.22 & 0.34 \\
\hline $\mathrm{CaO}$ & 0.16 & 0.11 & 0.17 & 0.15 & 0.14 & 0.10 & 0.15 & 0.07 & 0.04 & 0.04 & 0.12 & 0.07 & 0.11 & 0.04 & 0.02 & 0.07 & 0.05 & 0.09 \\
\hline Total & 95.8 & 95.9 & 95.5 & 95.2 & 94.8 & 94.5 & 95.0 & 95.8 & 96.5 & 94.3 & 94.9 & 94.5 & 96.1 & $96.1^{\circ}$ & 96.9 & 96.7 & 97.0 & 96.7 \\
\hline
\end{tabular}

Appendix E (continued).

\begin{tabular}{|c|c|c|c|c|c|c|c|c|c|c|c|c|c|c|c|c|c|c|}
\hline Hole & $597 \mathrm{C}$ & $597 \mathrm{C}$ & $597 \mathrm{C}$ & $597 \mathrm{C}$ & $597 \mathrm{C}$ & $597 \mathrm{C}$ & $597 \mathrm{C}$ & $597 \mathrm{C}$ & $597 \mathrm{C}$ & $597 \mathrm{C}$ & $597 \mathrm{C}$ & $597 \mathrm{C}$ & $597 \mathrm{C}$ & $597 \mathrm{C}$ & $597 \mathrm{C}$ & $597 \mathrm{C}$ & $597 \mathrm{C}$ & 597C \\
\hline Core-Sec. & $8-4$ & $8-4$ & $8-4$ & $8-5$ & $8-5$ & $8-5$ & $8-6$ & $8-6$ & $8-6$ & $9-1$ & $9-1$ & $9-1$ & $9-1$ & $9-1$ & $9-1$ & $9-4$ & $9-4$ & $9-4$ \\
\hline Position, cm & 23 & 23 & 23 & 49 & 49 & 49 & 56 & 56 & 56 & 94 & 94 & 94 & 129 & 129 & 129 & 93 & 93 & 93 \\
\hline $\mathrm{SiO}_{2}$ & 0.36 & 0.39 & 0.26 & 0.28 & 0.26 & 0.18 & 0.23 & 0.23 & 0.26 & 0.26 & 0.26 & 0.36 & 0.46 & 0.18 & 0.28 & 0.94 & 1.35 & 1.60 \\
\hline $\mathrm{TiO}_{2}^{2}$ & 18.93 & 20.47 & 19.51 & 21.01 & 18.95 & 23.92 & 22.51 & 26.52 & 16.96 & 18.69 & 20.72 & 23.17 & 22.10 & 18.49 & 19.17 & 26.53 & 24.28 & 25.02 \\
\hline $\mathrm{Al}_{2} \mathrm{O}_{3}$ & 1.40 & 1.17 & 1.60 & 1.77 & 1.95 & 1.32 & 0.60 & 1.48 & 0.78 & 1.25 & 1.07 & 2.23 & 1.62 & 2.83 & 0.90 & 0.54 & 0.52 & 0.49 \\
\hline $\mathrm{FeO}$ & 73.70 & 71.41 & 73.19 & 70.05 & 73.33 & 69.68 & 71.74 & 67.55 & 75.71 & 73.60 & 71.36 & 68.28 & 71.00 & 72.71 & 74.25 & 64.32 & 65.75 & 63.50 \\
\hline $\mathrm{MnO}$ & 0.41 & 0.44 & 0.44 & 0.54 & 0.48 & 0.46 & 0.50 & 0.57 & 0.64 & 0.64 & 0.50 & 0.54 & 0.54 & 0.43 & 0.53 & 1.25 & 1.03 & 1.44 \\
\hline $\mathrm{MgO}$ & 0.15 & 0.14 & 0.27 & 0.26 & 0.27 & 0.22 & 0.12 & 0.33 & 0.12 & 0.12 & 0.15 & 0.86 & 0.26 & 1.42 & 0.19 & 0.31 & 0.21 & 0.33 \\
\hline $\mathrm{CaO}$ & 0.28 & 0.15 & 0.11 & 0.07 & 0.04 & 0.07 & 0.07 & 0.06 & 0.07 & 0.05 & 0.04 & 0.10 & 0.04 & 0.05 & 0.14 & 0.36 & 0.47 & 0.77 \\
\hline Total & 95.2 & 9.42 & 95.4 & 94.0 & 95.3 & 95.8 & 95.8 & 96.7 & 94.5 & 94.6 & 94.1 & 95.5 & 96.0 & 96.1 & 95.5 & 94.3 & 93.6 & 93.1 \\
\hline
\end{tabular}

Appendix E (continued).

\begin{tabular}{|c|c|c|c|c|c|c|c|c|c|c|c|c|c|c|c|c|c|c|}
\hline Hole & $597 \mathrm{C}$ & $597 \mathrm{C}$ & $597 \mathrm{C}$ & $597 \mathrm{C}$ & $597 \mathrm{C}$ & $597 \mathrm{C}$ & $597 \mathrm{C}$ & $597 \mathrm{C}$ & $597 \mathrm{C}$ & $597 \mathrm{C}$ & $597 \mathrm{C}$ & $597 \mathrm{C}$ & $597 \mathrm{C}$ & $597 \mathrm{C}$ & $597 \mathrm{C}$ & $597 \mathrm{C}$ & $597 \mathrm{C}$ & $597 \mathrm{C}$ \\
\hline Core-Sec. & $10-2$ & $10-2$ & $10-2$ & $10-4$ & $10-4$ & $10-4$ & $10-6$ & $10-6$ & $10-6$ & $11-1$ & $11-1$ & $11-1$ & $11-3$ & $11-3$ & $11-3$ & $12-1$ & $12-1$ & $12-1$ \\
\hline Position, cm & 119 & 119 & 119 & 94 & 94 & 94 & 70 & 70 & 70 & 93 & 93 & 93 & 25 & 25 & 25 & 20 & 20 & 20 \\
\hline $\mathrm{SiO}_{2}$ & 0.21 & 0.23 & 0.18 & 0.18 & 0.18 & 0.16 & 0.15 & 0.15 & 0.18 & 0.18 & 0.16 & 0.13 & 0.15 & 0.15 & 0.15 & 0.16 & 0.16 & 0.28 \\
\hline $\mathrm{TiO}_{2}^{2}$ & 19.39 & 19.55 & 19.75 & 20.63 & 21.76 & 20.56 & 22.50 & 20.96 & 21.86 & 19.71 & 22.14 & 22.65 & 21.88 & 21.49 & 21.88 & 22.24 & 22.26 & 22.03 \\
\hline $\mathrm{Al}_{2} \mathrm{O}_{3}$ & 1.23 & 1.48 & 1.31 & 1.05 & 1.18 & 1.00 & 1.05 & 1.03 & 1.30 & 1.93 & 1.38 & 1.38 & 1.47 & 1.47 & 1.52 & 1.98 & 1.80 & 1.80 \\
\hline $\mathrm{FeO}$ & 74.32 & 73.93 & 74.71 & 73.79 & 72.50 & 73.57 & 72.41 & 73.46 & 72.62 & 72.20 & 72.02 & 71.72 & 71.11 & 71.76 & 71.56 & 71.36 & 70.68 & 70.95 \\
\hline $\mathrm{MnO}$ & 0.53 & 0.48 & 0.51 & 0.58 & 0.51 & 0.60 & 0.50 & 0.55 & 0.55 & 0.44 & 0.55 & 0.48 & 0.50 & 0.57 & 0.46 & 0.54 & 0.53 & 0.54 \\
\hline $\mathrm{MgO}$ & 0.24 & 0.34 & 0.29 & 0.36 & 0.48 & 0.41 & 0.51 & 0.34 & 0.51 & 1.35 & 0.94 & 0.96 & 0.92 & 0.95 & 0.86 & 1.39 & 1.32 & 0.99 \\
\hline $\mathrm{CaO}$ & 0.04 & 0.05 & 0.04 & 0.02 & 0.02 & 0.04 & 0.04 & 0.02 & 0.02 & 0.07 & 0.04 & 0.02 & 0.02 & 0.06 & 0.05 & 0.02 & 0.04 & 0.04 \\
\hline Total & 96.0 & 96.1 & 96.8 & 96.6 & 96.6 & 96.3 & 97.2 & 96.5 & 97.0 & 95.9 & 97.2 & 97.3 & 96.1 & 96.5 & 96.5 & 97.7 & 96.8 & 96.6 \\
\hline
\end{tabular}

